\title{
Spring Studies and A Decision-Making Process to Guide Groundwater Contamination Prevention in an Agricultural Karst Basin
}

Erin D. Murphy

West Virginia University

Follow this and additional works at: https://researchrepository.wvu.edu/etd

\section{Recommended Citation}

Murphy, Erin D., "Spring Studies and A Decision-Making Process to Guide Groundwater Contamination Prevention in an Agricultural Karst Basin" (2013). Graduate Theses, Dissertations, and Problem Reports. 231.

https://researchrepository.wvu.edu/etd/231

This Thesis is protected by copyright and/or related rights. It has been brought to you by the The Research Repository @ WVU with permission from the rights-holder(s). You are free to use this Thesis in any way that is permitted by the copyright and related rights legislation that applies to your use. For other uses you must obtain permission from the rights-holder(s) directly, unless additional rights are indicated by a Creative Commons license in the record and/ or on the work itself. This Thesis has been accepted for inclusion in WVU Graduate Theses, Dissertations, and Problem Reports collection by an authorized administrator of The Research Repository @ WVU. For more information, please contact researchrepository@mail.wvu.edu. 


\title{
Spring Studies and A Decision-Making Process to Guide Groundwater Contamination Prevention in an Agricultural Karst Basin
}

\author{
Buckeye Creek Basin, Greenbrier County, \\ West Virginia
}

\author{
Erin D. Murphy
}

Thesis submitted to the Eberly College of Arts and Sciences at West Virginia University in partial fulfillment of the requirements for the degree of

Master of Arts in Geography

\author{
J. Steven Kite, Ph.D., Chair \\ Dorothy Vesper, Ph.D. \\ Doug Boyer, Ph.D.
}

Department of Geology and Geography

Morgantown, West Virginia

2013

Keywords: Karst, Best Management Practices, Groundwater Contamination, Buckeye Creek Copyright 2013 Erin D. Murphy 


\begin{abstract}
Spring Studies and a Decision-Making Process to Guide Groundwater Contamination Prevention in an Agricultural Karst Basin

Buckeye Creek Basin, Greenbrier County, West Virginia
\end{abstract}

\title{
Erin D. Murphy
}

Groundwater contamination is a potential major health and environmental issue in karst aquifers because of rapid surface water to groundwater connections and conduit-dominated flow that may allow contaminants to move great distances from their source in a very short amount of time. Agricultural contaminants are a significant problem in Buckeye Creek basin in Greenbrier County, West Virginia. Pasquarell and Boyer (1995) found that cattle grazing near sinking streams, sinkholes, and springs contribute to the elevated levels of fecal coliform bacteria in the groundwater. Six sites in Buckeye Creek basin were monitored for fecal coliform contamination and then analyzed in order to determine where best management practices (BMPs) could result in the most effective water quality improvement. Water quality variables including fecal coliform density and fecal coliform loading were used to develop a methodology for prioritizing the monitored sites for BMP implementation. Models using existing dye traces and GIS-based data were used to identify the key areas contributing contamination to these sites. Three sites in the basin were found to be high priority areas for BMP implementation and potential contamination source areas were identified for these sites. 


\section{Table of Contents}

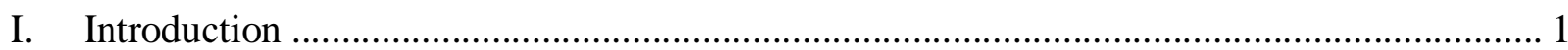

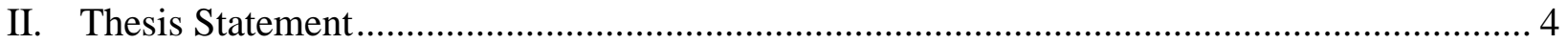

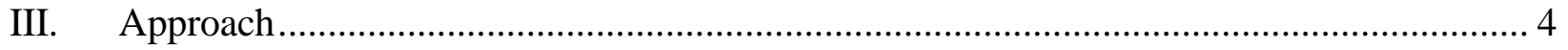

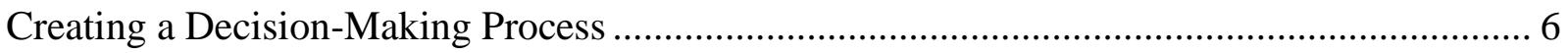

Using Fecal Coliform Bacteria as an Indicator of Groundwater Contamination ......................... 9

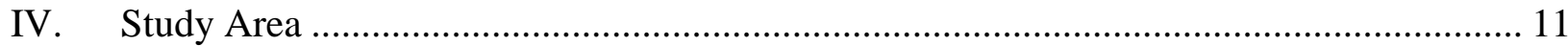

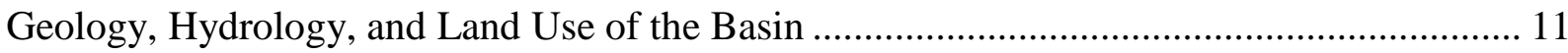

Rationale for Conducting the Study in Buckeye Creek Basin ................................................ 16

V. Previous Studies and Existing Data..................................................................................... 17

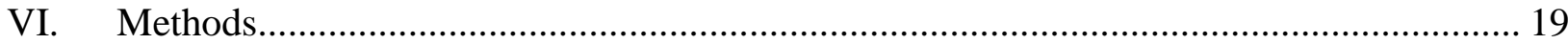

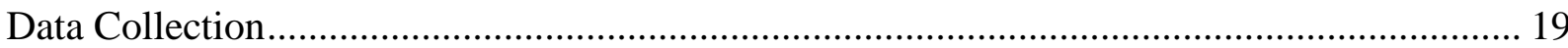

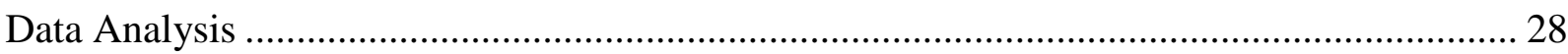

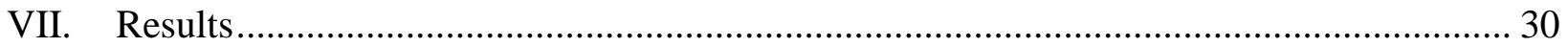

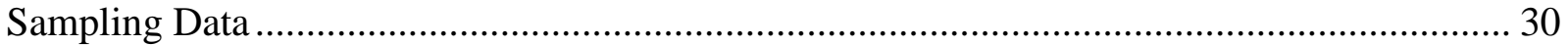

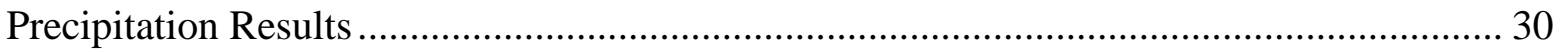

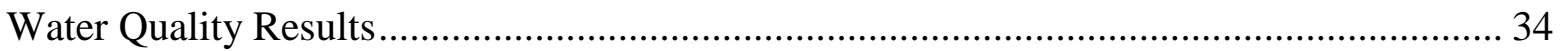

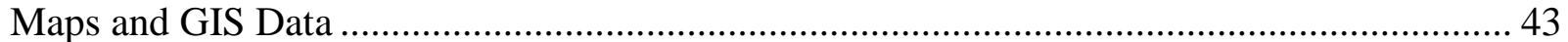

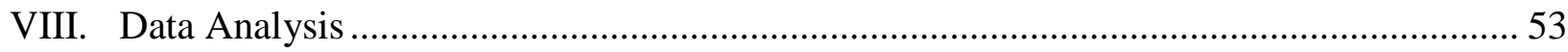

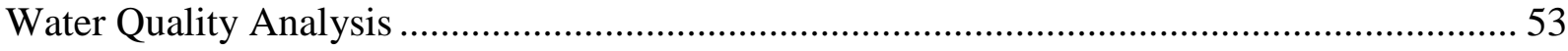

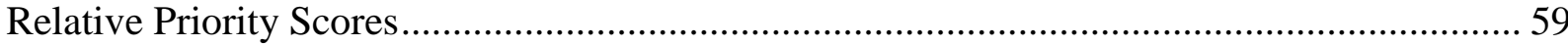

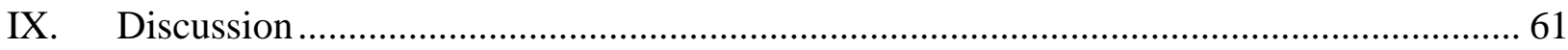

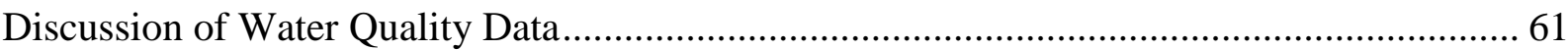

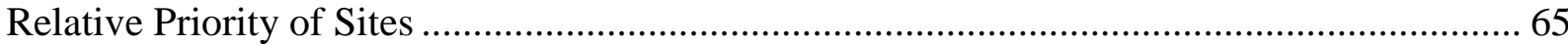

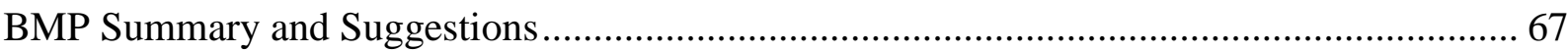

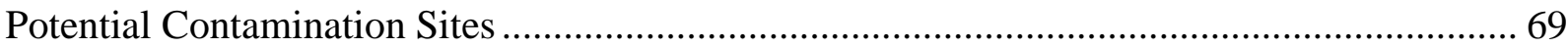

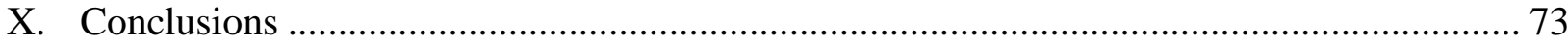

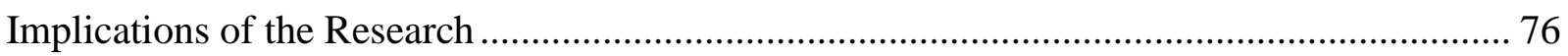

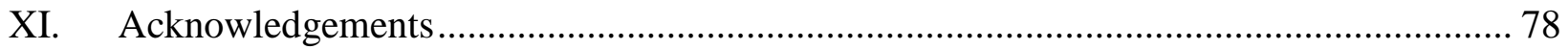

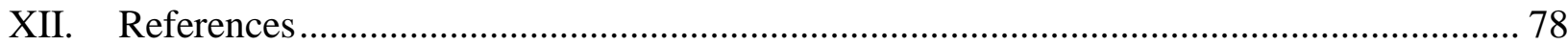




\section{List of Tables}

Table 1: Example Relative Priority Score Spreadsheet .............................................................

Table 2: WVDEP Water Quality Data Summary ………….................................................19

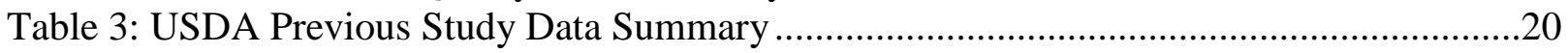

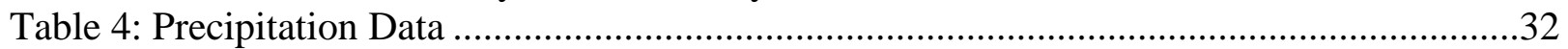

Table 5: Sampling and Data Collection Schedule …………..................................................36

Table 6: Sample Fecal Coliform Concentration in CFU/100 ml ..............................................37

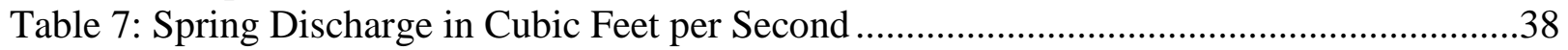

Table 8: Site Fecal Coliform Loading in CFU/s ......................................................................39

Table 9: Sample Alkalinity in meq/L (and $\mathrm{mg} / \mathrm{L}$ as $\mathrm{HCO}_{3}{ }^{-}$) ..................................................40

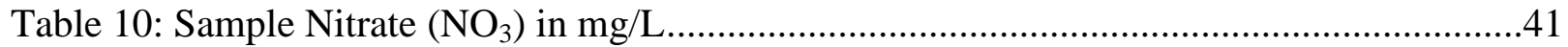

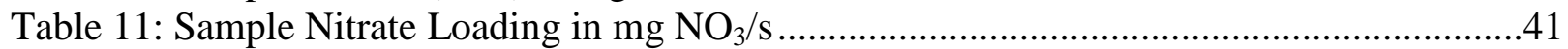

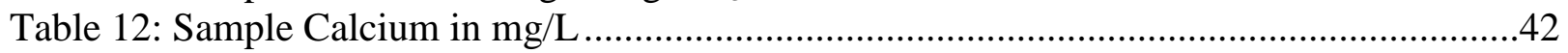

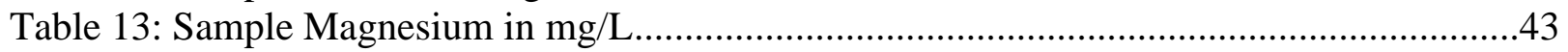

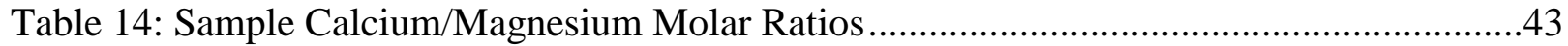

Table 15: Spearman's Rank Correlation Coefficients for Basin-wide Data................................59

Table 16: Spearman's Rank Correlation Coefficients for Baseflow Data ....................................60

Table 17: Relative Priority Scores for Baseflow Samples .........................................................61

Table 18: Relative Priority Scores for Storm Samples ...............................................................61

Table 19: Location of Highest Observed FC Concentrations and FC Loading by Date .............65

\section{List of Figures}

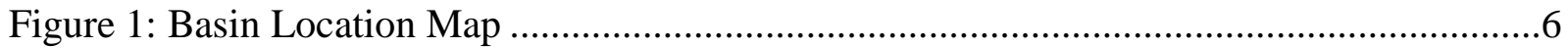

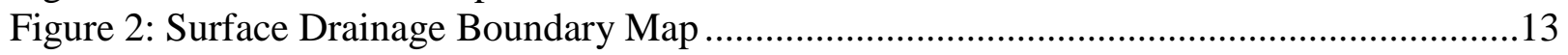

Figure 3: Geology of the Study Area .................................................................................14

Figure 4: Plan View Map of Buckeye Creek Cave System......................................................15

Figure 5: Map of Drainage Basins of Spring Creek …………………..................................16

Figure 6: Change in Spring Water Temperature with Precipitation ............................................34

Figure 7: Buckeye Creek Surface Basin Boundary and Known Subsurface Connections ...........45

Figure 8: Buckeye Creek Drainage Basin Land Use Map .......................................................47

Figure 9: Buckeye Creek Drainage Basin Karst Agricultural Land Map ...................................49

Figure 10: Sample Site Surface Runoff Subwatersheds ..........................................................51

Figure 11: Estimated Groundwater Surface Elevation Interpolated by Kriging ..........................53

Figure 12: Distributions of Fecal Coliform Densities by Site ...................................................56

Figure 13: Distributions of Fecal Coliform Loading by Site .....................................................57

Figure 14: Locations of Important Sites for BMP Consideration ................................................73

Figure 15: Locations of Suggested Surface Channels for Riparian BMPs.................................75

\section{Appendices}

Appendix A: WVDEP Data

Appendix B: USDA-ARS Data

Appendix C: Springs and Insurgences of Buckeye Creek Basin 
Appendix D: Description and Map of Study Sample Site Locations Appendix E: Previous Dye Traces and Subsurface Connections Appendix F: Photos

Appendix G: Quality Control Data 


\section{Introduction}

While groundwater contamination is a concern everywhere, it is an issue that is especially critical in karst terrains. Many karst aquifers are distinct because of the direct connectivity between surface water and groundwater. These direct connections have a critical impact on groundwater quality for two reasons. First, the direct connections mean that potential contaminants can reach groundwater very rapidly, often faster than they can be treated, removed, or even detected. Second, contaminants reach groundwater without undergoing the natural purification processes that occur in most other geologic settings. In non-karst systems, surface streams allow some level of purification or decontamination of water throughout the drainage basin. This decontamination occurs through physical filtration through sediment, through biological breakdown by microorganisms and plants, through solar UV radiation, and through aeration from turbulent stream flow (Spellman, 1996; Hipsey et al., 2008). Water that percolates through the soil before entering streams is also filtered to some extent in non-karst systems. However, there is little potential for filtration in the thin soils prevalent in karst terrain (White, 1988). This lack of purification and filtration creates a critical public health issue because it is estimated that half of waterborne disease in the United States is caused by the use of groundwater that has not been adequately treated (Boyer and Pasquarell, 1999).

Some karst aquifers may be more vulnerable to groundwater contamination than others due to the flow mechanics of the aquifer. Karst systems may be more vulnerable if conduit flow and sinkhole injection are common. Spring discharge and water chemistry have been observed to be highly variable in carbonate aquifers with predominantly conduit flow, and less variable in carbonate aquifers with more diffuse flow (Shuster and White, 1971). Conduit flow may further 
compound groundwater contamination issues by allowing contaminants to move great distances from their source in a very short amount of time (Boyer and Pasquarell, 1995). Contaminants can also disperse in ways that are unexpected and much less predictable than in a non-karst system. Pollutants can be expected to disperse in a plume in non-karst aquifers and can typically be detected and monitored by wells placed in a downslope direction. In karst systems, the pollutants may flow through conduits that completely bypass monitoring wells (Palmer, 2007), or be transferred across surface watershed boundaries via networks of subsurface connections (Younos et al., 2001).

Groundwater contamination can cause a variety of illnesses in both people and livestock that drink the water, including acute gastro-intestinal infections and more chronic ailments, such as blue-baby syndrome and infertility (Kleinjans et al, 1991; U.S. Environmental Protection Agency, 2006). Even when contamination does not cause illness, it can cause unpleasant effects such as poor taste and odor in well water. Moreover, groundwater pollution can destroy specialized karst ecosystems. Increases in certain pollutants can cause lasting damage to aquatic cave organisms, some of which are endemic or endangered (Ryan and Meiman, 1996; Veni, 2004). Once contamination occurs in karst areas, a rapid downstream impact can be expected because of the difficulty in retarding or removing contaminants in complex underground conduit systems. Karst water contamination is a major issue in the Appalachian region, where about 18 percent of land is karst terrain (Boyer and Pasquarell, 1996).

Agriculture is a known contributor to surface and groundwater contamination. The U.S. Environmental Protection Agency (EPA) listed agriculture as a source of contamination for 48 percent of impaired river segments in the United States during 2002 (Boyer, 2005). In West Virginia, agriculture is a major contributor to groundwater pollution in karst aquifers. About a 
third of the Appalachian region's agricultural production comes from karst land (Pasquarell and Boyer, 1995). Previous studies have found numerous agricultural pollutants in karst springs in southeastern West Virginia, including elevated nutrient concentrations (Boyer and Pasquarell, 1995; Alloush et al, 2003), fecal coliform bacteria (Pasquarell and Boyer, 1995) and Cryptosporidium parvum (Boyer and Kuczynska, 2003). The agricultural contaminants in this area are primarily associated with livestock operations. Studies have shown a direct relationship between livestock activity and nitrate concentration and fecal coliform bacteria levels in karst streams and springs (Boyer and Pasquarell, 1995; 1996; 1999). Pasquarell and Boyer (1995) also found that cattle grazing near sinking streams, sinkholes, and springs contribute to the elevated levels of fecal coliform bacteria in the groundwater.

In addition to pathogens and nutrients, sedimentation is also a problem in agricultural karst lands. Sediment can disturb karst ecosystems, cause poor water quality in wells, and transport pathogens such as fecal coliform bacteria (Hipsey, et al. 2008). Karst terrain has an extraordinarily high capacity to transport sediment through soil piping into cracks and fissures, sediment loss into sinkholes and sinking streams, and movement and eventual removal of sediment through underground conduits and cave streams. Increased sediment loss can be caused by clearing karst land for agriculture or by over-grazing in and near karst streams, sinkholes, and dry surface channels.

Because of the poor filtration and rapid movement of water in karst aquifers, contamination prevention is the best way to protect groundwater quality in karst areas. Best management practices (BMPs) such as sinkhole filters, livestock exclusion fences, and nutrient management programs can be used to prevent agricultural contaminants from impacting karst groundwater. A voluntary, federally funded project helped landowners implement BMPs at 
sites within the Greenbrier River Hydrologic Unit of southeastern West Virginia beginning in 1990. Funding was provided under the President's Water Quality Initiative and the Environmental Quality Incentives Program (EQIP). The funding was distributed based on voluntary landowner participation in cost sharing and technology transfer programs, resulting in dispersed BMP placement with little attention paid to intensity of local contamination or to potential for water quality improvement. A subsequent evaluation found that the projects achieved little improvement on watershed-scale water quality (Boyer, 2005). This conclusion suggests that more targeted placement of best management practices at the most critical problem areas may be more effective in improving water quality on both a local and watershed scale. This study demonstrates one way in which stakeholders in a karst drainage basin could focus conservation efforts on the most critical problem areas.

\section{Thesis Statement}

Problem areas within a karst watershed can be analyzed and ranked in order to implement best management practices in locations where they will result in the most effective water quality improvement. The goal of this project was to use water quality parameters, including fecal coliform concentration, to develop a methodology for identifying key areas for conservation efforts in the Buckeye Creek drainage basin in Greenbrier County, West Virginia (Figure 1).

\section{Approach}

This research aimed to identify critical water quality problem areas in Buckeye Creek basin in order to maximize the results of conservation efforts in the watershed. The study 
focused on Buckeye Creek basin (Figure 1) as an example of how a systematic decision-making process may be used to identify contamination outputs and rank the associated contamination sources that they are linked to in a karst drainage basin. This study is also intended to serve as an example of how this process could be carried out in other drainage basins with similar geology and land use. Buckeye Creek basin has karst development and land use similar to many other watersheds in the Greenbrier River Hydrologic Unit - thus, this study may serve as a useful guide to address many of the same agricultural contaminant issues over a larger area. A decision-making process similar to the one used in this study could be extended to other karst basins throughout the eastern United States by adjusting the process for the specific contamination issues and characteristics of each basin.

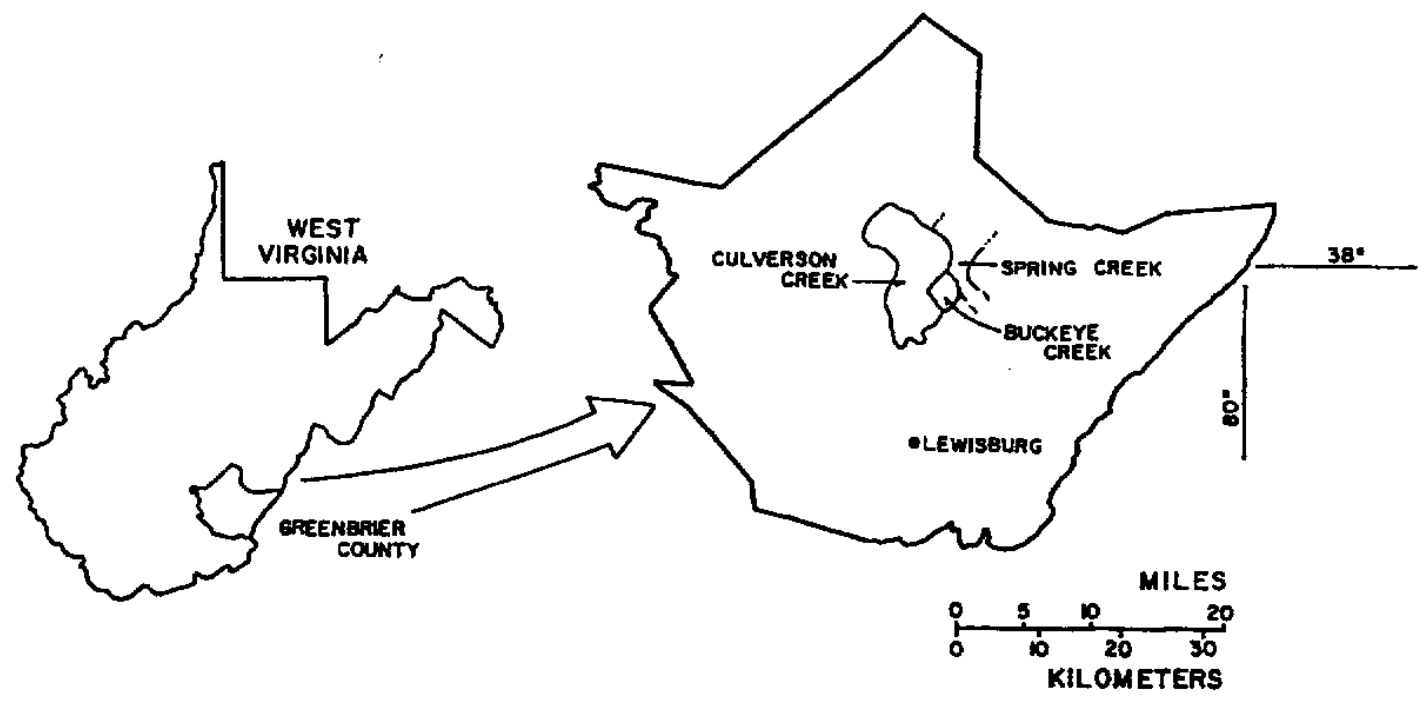

Figure 1: Location of Buckeye Creek drainage basin and Culverson Creek drainage basin within Greenbrier County, West Virginia. Adapted from Dasher and Boyer, 2000.

Potential contamination sources in the basin were identified using land use data, land management plans, and known hydrologic connections. These potential sources were then 
evaluated and ranked so that BMPs implemented in the future can be targeted at the most critical sites. Previous studies indicate that targeted local efforts can make a difference in problem areas within a karst watershed (Boyer and Pasquarell, 1996, 1999; Boyer, 2005, 2008). For the purposes of this study, potential contamination sources were identified as areas or specific sites that are considered to be major contributing sources of agricultural contaminants. Agricultural land containing streams and insurgences with known connections to contaminated springs or surface or subsurface streams was assumed to be a possible source of contamination. Previous dye studies completed in the basin were used to identify connections between various insurgences, resurgences, and streams in the basins, as well as karst drainage area boundaries. These dye tracings were primarily completed by Dasher and Balfour (1994) and Dasher and Boyer (2000). A groundwater map of the basin was compiled for this study using the previously delineated subsurface connections and basin boundaries. The groundwater map was used in conjunction with land use, elevation, geologic data, and observed contamination levels to identify potential contamination source areas using ArcGIS software.

Once potential contamination sources were identified, possible BMPs or conservation projects were suggested and ranked in order of the greatest potential for water quality improvement in the watershed. A decision-making process was established in order to rank the potential water quality improvement projects. Knowledge gained from data collected both before and during the study were used in order to rank the potential projects according to this decision-making process.

\section{Creating a Decision-Making Process}

For the purposes of this study, decisions on how to prioritize potential projects were made with the intention to improve water quality on a watershed scale and benefit the health and 
welfare of the general public who live within and downstream of Buckeye Creek Basin, as defined in the following system. Use of water was the first criteria for ranking the potential projects. Water sources used for domestic consumption were ranked the most important to protect. Water consumed by livestock, which are of great economic importance to the people of the area, were considered next most important. Water that residents may come into contact with on a regular basis, either recreationally or otherwise, was considered equally as important as agricultural water. Finally, this study considered water that is not directly used by people but that is important to the ecology and inherent environmental quality of the basin. The amount of fecal coliform loading that the source contributes was the second criteria for ranking the contamination sources. For two sources that have the same use, or drain to the same contaminated area, the source contributing greater amounts of fecal coliform bacteria was considered more important to address.

The decision-making process was set up and carried out using a Microsoft Excel spreadsheet. The spreadsheet was used to calculate a relative priority score (RPS) for each water source based on water use, contamination level, and discharge volume (Table 1). Each supply source starts with an unadjusted RPS of 1 . The "Use" column weights priority by multiplying domestic supply sources by 100 , agricultural and recreational supply sources by 10 , and other sources by 1 . This weighting system was used because water use is considered an important factor in this study. Order-of-magnitude differences were used rather than a smaller multiplying factor due to the extremely large variations found in fecal coliform densities, both between sites and within sites on different dates. This weighting gives a domestic supply source the same or greater relative importance as most other sources even if it has a smaller volume. Other 
weighting systems could be devised to assign priorities based on other factors such as stakeholder interest or cost of improvements.

\begin{tabular}{|c|c|c|c|c|c|c|c|}
\hline Source & Use & Concentration & Discharge & FC Loading & Use Factor & $\begin{array}{c}\text { Contamination } \\
\text { Factor }\end{array}$ & $\begin{array}{c}\text { Relative } \\
\text { Priority Score }\end{array}$ \\
\hline & & (CFU/100 ml) & (L/s) & (CFU/second) & (unitless) & (unitless) & (Relative Units) \\
\hline Example 1 & Domestic & 107 & 142 & 152,000 & 100 & 1 & $15,200,000$ \\
\hline Example 2 & Other & 141 & 227 & 320,000 & 1 & 1 & 320,000 \\
\hline Example 3 & Agricultural & 200 & 2830 & $5,660,000$ & 10 & 1 & $56,600,000$ \\
\hline Example 4 & Recreation & 2 & 4250 & 85,000 & 10 & 0 & $\mathrm{C}$ \\
\hline Example 5 & Other & 92 & 3570 & $3,280,000$ & 1 & 1 & $3,280,000$ \\
\hline Example 6 & Agricultural & 64 & 3540 & $2,270,000$ & 10 & 1 & $22,700,000$ \\
\hline
\end{tabular}

Instructions: Enter data in gray cells. Values for the following columns will be calculated from entered data. Units must be consistent for all values in a column.

Table 1: Relative Priority Score (RPS) calculation spreadsheet. RPS is calculated using fecal coliform concentration, source discharge, and water use to determine the priority for addressing contaminated water sources. The highest RPS indicates the highest priority for groundwater protection.

The "Concentration" column in Table 1displays the fecal coliform bacteria (FC) density values (in CFU/100 ml) and is used to calculate the Contamination Factor. The "Discharge" column displays the discharge of the spring or stream at the time of sampling (in $\mathrm{L} / \mathrm{s}$ ). Due to the rapid variability of discharge and contamination levels in many karst systems, all sites should be sampled as close to the same time as possible in order for the discharge and concentration values to provide a relevant comparison. The "FC Loading" column is determined by multiplying the concentration by a conversion factor of 10 (CFU/100 $\mathrm{ml}$ to CFU/L) and multiplying this value by the discharge. The product of concentration and discharge is used to rank the sources based on FC contaminant loading in the watershed in order to target the most important locations for groundwater protection. The "Contamination Factor" column shows 
whether the contamination level in the supply is above or below West Virginia Department of Environmental Protection (WVDEP) quality standards for fecal coliform bacteria in drinking water. If the mean contamination level is below the criteria, the assigned contamination factor is 0 . If the contamination level is above the criteria, the contamination factor is 1 . This binary scoring system removes "uncontaminated" sources to prevent unimpaired groundwater from receiving a high RPS based on water use and discharge. The adjusted RPS is calculated in the "Score" column by multiplying the FC loading by the use factor and the contamination factor. This process was used to calculate RPS scores for the sites in the basin for two data sets. The initial data set collected in this study contained mean FC concentration and mean discharge for 4 to 6 baseflow samples for each site, whereas the second data set addressed FC concentration and discharge for a single storm sample.

\section{Using Fecal Coliform Bacteria as an Indicator of Groundwater Contamination}

Fecal coliform bacteria density was used as the primary indicator for critical contamination areas in this study. The presence of fecal coliform bacteria in water is thought to be the best indicator of fecal contamination and is also a good indicator of human disease risk associated with contact with or consumption of contaminated water (Bitton, 1999; Madigan et al., 2003). FC concentrations are also good indicators of agricultural impacts on water quality in the study area. Previous studies have shown a direct relationship between livestock activity and nitrate and fecal coliform concentration in subsurface streams and springs in similar basins in southeastern West Virginia (Boyer and Pasquarell, 1995, 1996, 1999). Fecal coliform bacteria were identified as the major source of impairment of Spring Creek in 2008 in the West Virginia water quality assessment report (US EPA, 2010), making FC concentrations a relevant and important contamination issue for this tributary basin. FC bacteria can also be introduced to 
watersheds by other sources such as septic tanks, but direct observation of land use in this area indicates FC input from sources other than agriculture is minimal in this basin.

There are several biological and physical characteristics that make FC a useful indicator. Previous studies have concluded that the mechanism of transport of FC in karst aquifers is primarily surface runoff (Ryan and Meiman, 1996; Mahler, et al, 2000; Boyer and Kuczynska, 2003). Surface runoff as a transport mechanism was demonstrated in a similar basin in southeast West Virginia by the fact that fecal coliform densities at springs in the Hole Basin correlated with storm flow and were greatest at peak flow (Boyer and Kuczynska, 2003). In addition, fecal coliform bacteria have been shown to readily associate with suspended sediment in karst aquifers (Mahler et al., 2000). Ryan and Meiman (1996) showed that concentrations of both fecal coliform bacteria and suspended sediment increased significantly during runoff events for very short periods of time. Mahler et al. (2000) showed that the highest concentrations of fecal coliforms entered the groundwater when total suspended sediment loads were greatest. This mechanism of transport means that traditional physical BMPs that target both sediment and associated bacteria and contaminants should be effective at preventing or impeding FC from reaching the groundwater. Such traditional BMPs may include vegetated buffers or filter strips, sinkhole filters, streambank protection efforts, riparian vegetation, animal exclusion fences around streams and sinkholes, and water distribution systems for livestock. Sinkhole filters have been evaluated for effectiveness in this area and shown to improve FC concentrations significantly (Boyer, 2008). Petersen and Vondracek (2006) also predicted through hydrologic modeling that vegetated buffers around sinkholes could significantly improve ground and surface water quality in karst areas through removal of sediment and sediment-bound contaminants, including bacteria. The positive response to BMPs makes FC a more useful indicator for this 
study than solute contaminants, like nitrate, which may require different types of conservation efforts such as nutrient management plans. Finally, since fecal coliform bacteria die off rather than being held in the aquifer to be later released, the FC density in groundwater should decrease once the source is removed. Unlike contaminants that are likely to be stored for some time, FC concentrations should show improvement soon after a BMP is implemented or the source of contamination is removed (Boyer and Kuczynska, 2003).

\section{Study Area}

\section{Geology, Hydrology, and Land Use of the Basin}

The study area is the Buckeye Creek drainage basin, a $15 \mathrm{~km}^{2}$ catchment within the greater Greenbrier River Hydrologic Unit in southeastern West Virginia (Figure 1) (Dasher and Balfour, 1994). The basin is moderately hilly, with elevations varying from approximately 550 to $825 \mathrm{~m}$ (1800 to $2700 \mathrm{ft}$ ) (Figure 2) (Dasher and Balfour, 1994). The karst hydrology of Buckeye Creek basin is similar to other basins in southeastern West Virginia because of the dominance of limestones of the Mississippian Greenbrier Group bedrock throughout the Greenbrier River, upper Elk, and upper Tygart River hydrologic units. Conduit flow is predominant in this area (Jones 1997). 


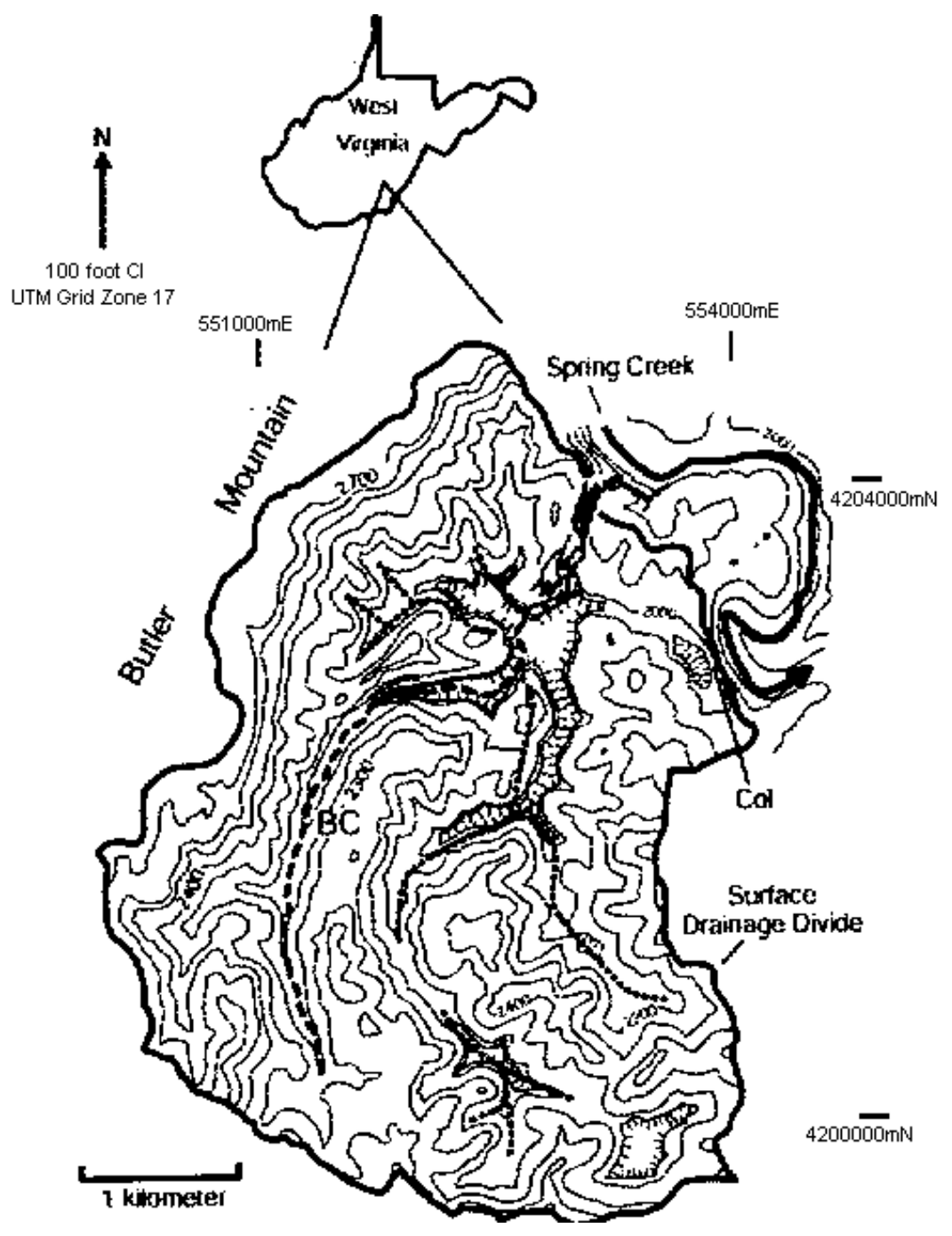

Figure 2: Surface drainage boundary and topography of Buckeye Creek basin. Adapted from Springer 2002.

Buckeye Creek basin is located along the contact of the Greenbrier outcrop belt with the Mauch Chunk Group in central Greenbrier County (Figure 3). The Greenbrier Group contains several limestone formations, interlayered with shale formations. The upper three formations of the Greenbrier Group are exposed in the drainage basin, with most of the karst development occurring in the third unit from the top, the Union Limestone. The Union Limestone is overlain by the Greenville Shale and Alderson Limestone, which are capped on the higher ridges by the 
more resistant Mississippian Mauch Chunk Group shale and sandstone west of the Greenbrier outcrop belt and along the western watershed boundary. Underlying the Greenbrier Group, Mississippian shales and sandstones of the MacCrady and Price formations are exposed east of the watershed (Cardwell, et al., 1968).

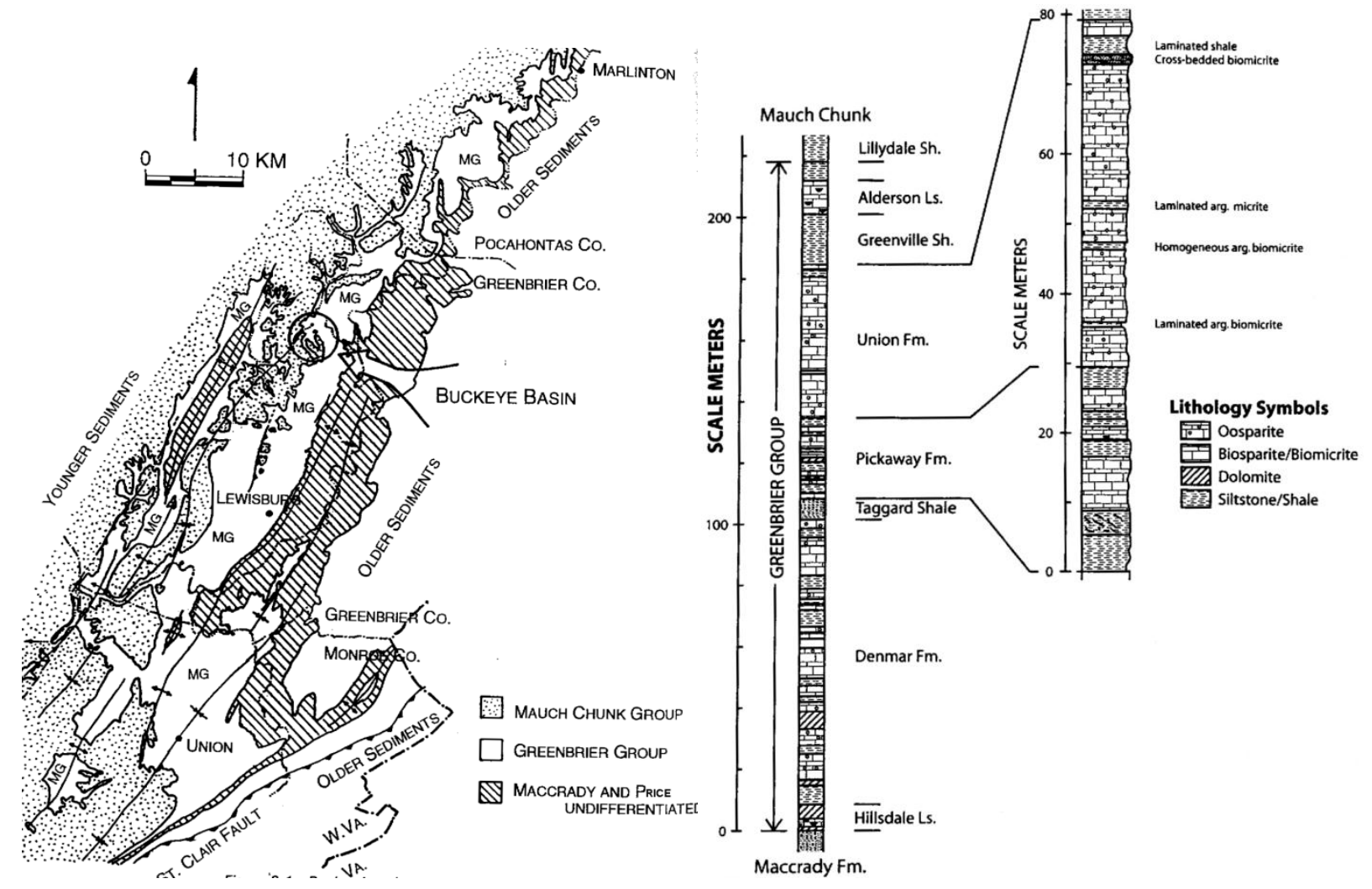

Figure 3: (Left) Geology of the study area, showing the Greenbrier Group contact with the Mauch Chunk Group within Buckeye Creek basin. Adapted from Dasher and Balfour, 1994. (Right) Stratigraphic column of the Greenbrier Group along Spring Creek. Buckeye Creek Cave is developed in the Union Formation. Adapted from Springer 2002.

Karst development in the basin is extensive. The Buckeye Creek-Rapps Cave system (Figure 4) currently carries the drainage from the basin in an underground stream that runs over $1800 \mathrm{~m}(5800 \mathrm{ft})$ before resurging near the entrance to Spencer Cave. The cave system consists 
of five known levels, with the stream only running through the lowest level at normal flow. The vertical relief of the entire cave system is $58 \mathrm{~m}$ (190 ft) (Dasher and Balfour, 1994).

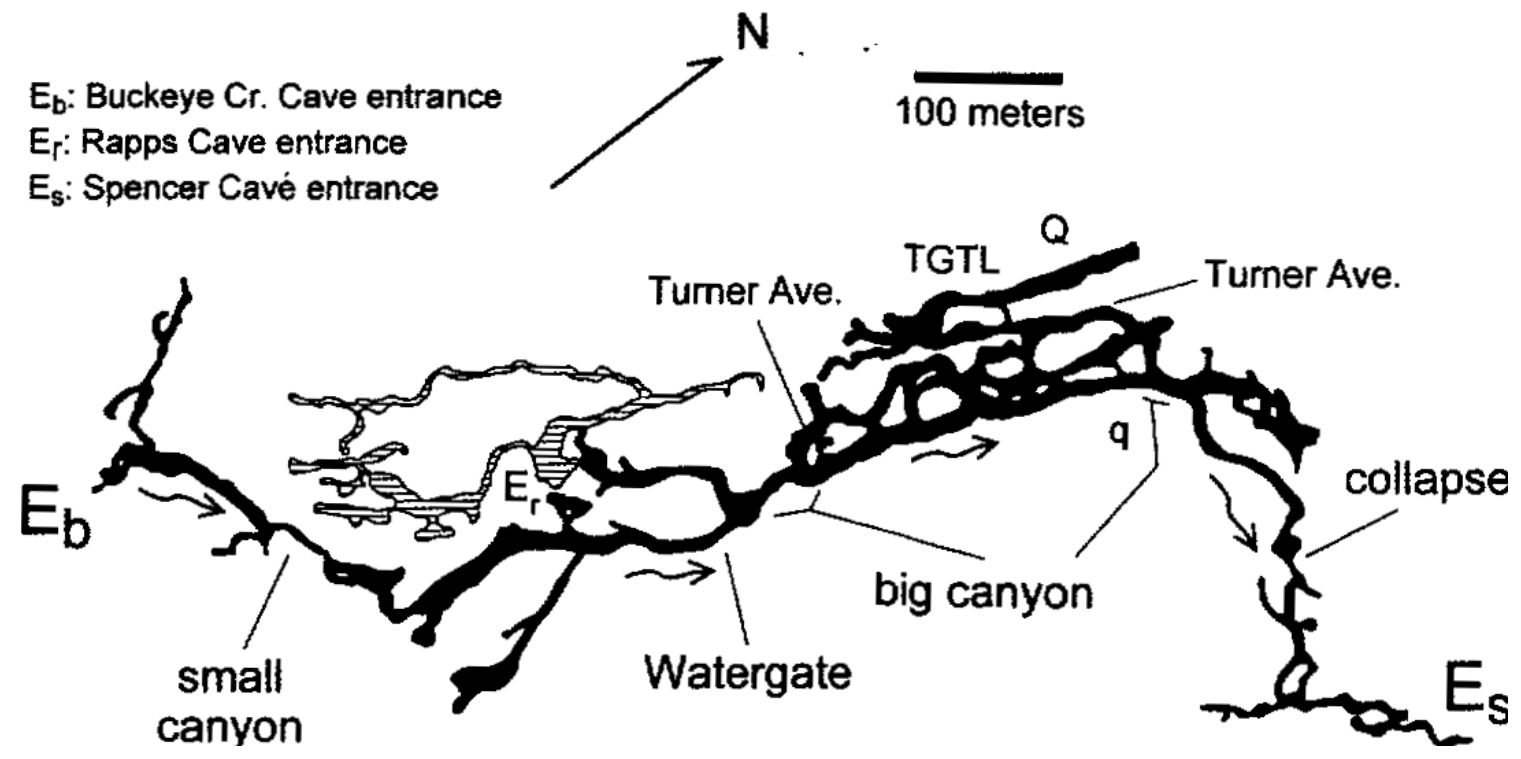

Figure 4: Plan view of the Buckeye Creek Cave system (shown in black) and the Rapps Cave System (shown hatched). Arrows show Buckeye Creek flow direction. Adapted from Springer 2002.

The basin is bordered by The Hole basin to the east, Culverson Creek basin to the west, and Davis Spring basin to the south, and Spring Creek basin to the north (Figure 5). Buckeye Creek drains into Spring Creek, a Greenbrier River tributary, primarily from the Spencer Cave resurgence, an outlet in the northeastern part of the basin. Part of the drainage from the upper portion of the Buckeye Creek basin is pirated underground into Culverson Creek basin (Dasher and Balfour, 1994). The combined drainage from Culverson Creek then resurges at Spring Creek downstream from the point where Buckeye Creek enters Spring Creek. The northwest boundary of the basin is formed by Butler Mountain and the eastern boundary roughly follows Spring Creek (Dasher and Balfour 1994). Buckeye Creek basin is a relatively well-defined 
catchment and is one of Spring Creek's largest tributary basins (Dasher and Balfour, 1994).

Reaches of both Spring Creek and Greenbrier River were listed on the Environmental Protection Agency's 303D list of impaired waters in 2008, with fecal bacteria listed as a cause of impairment (U.S. Environmental Protection Agency, 2010).

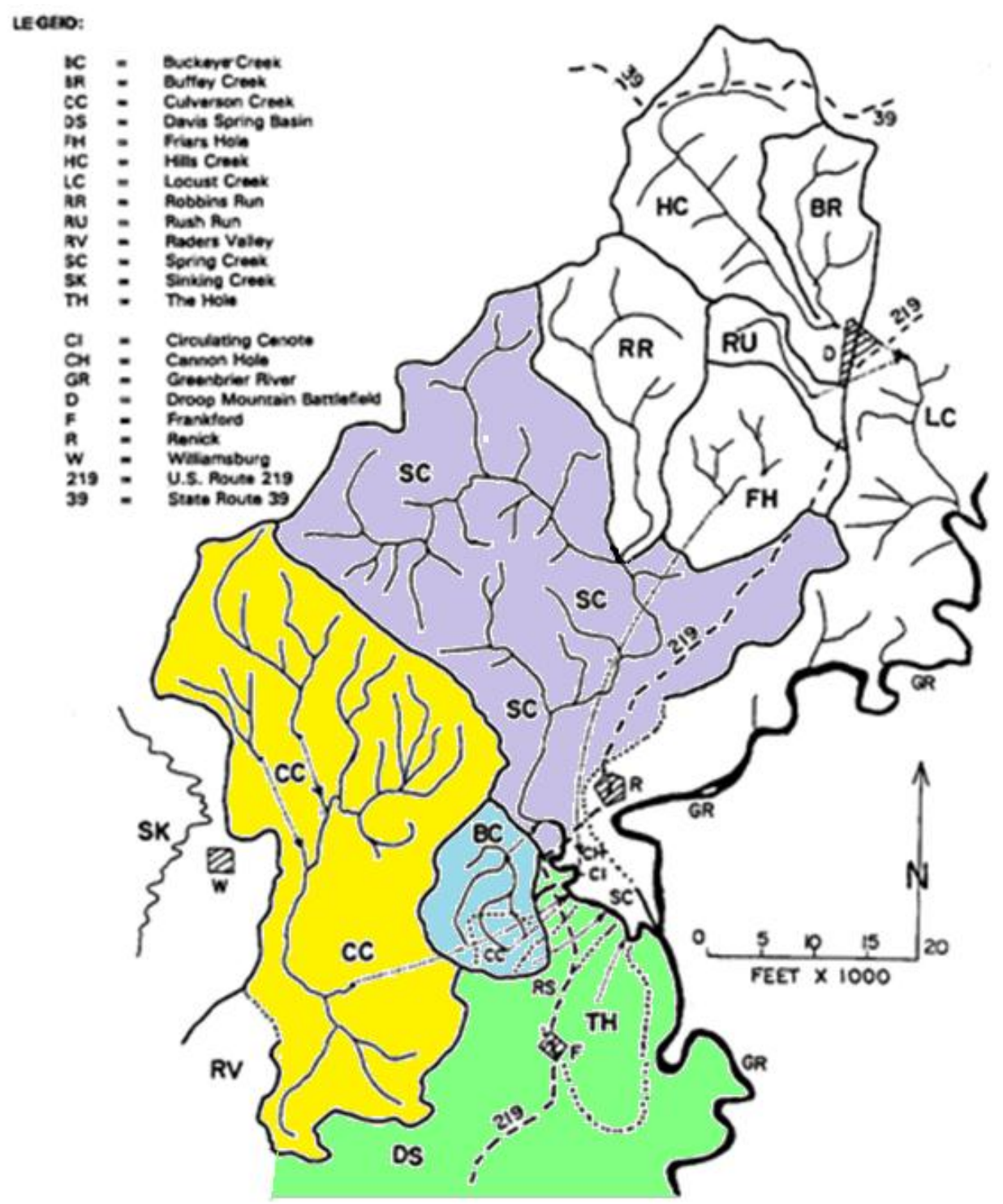

Figure 5: Karst basins draining into Spring Creek. Note the connected flow between Buckeye Creek basin and Culverson Creek basin. Numbers denote highway route numbers. Adapted from Dasher and Boyer 2000. 
Streams draining from the Mauch Chunk Group feed Buckeye Creek. The headwaters begin on clastic rock and have not eroded down to the level of the Union Limestone. Most tributaries to Buckeye Creek begin on the east side of Butler Mountain along the northwest boundary of the basin. Wherever the tributaries and main stem of Buckeye Creek breach the Union Limestone, surface runoff drains into the subsurface under most flow conditions. The surface valley is intact and provides an overflow for the subsurface drainage during times of heavy runoff. Subsurface and surface drainage flow through Buckeye Creek Cave into Spring Creek. The drainage from Buckeye Creek Cave resurges at Spencer Cave in the Spring Creek valley, forming the only known discharge route into Spring Creek other than the drainage that is pirated into Culverson Creek basin (Dasher and Balfour, 1994). Buckeye Creek has 11 known inflows within Buckeye Creek Cave where additional water has been traced from the surface to the cave. Two streams flow into Buckeye Creek northwest of the cave entrance, and have been confirmed by dye tracing to drain nearby Turner Hollow. Another source, Little Soaking Creek, drains Rapps Cave into Buckeye Creek Cave. Other inflows into the cave have been confirmed to be alternate routes for surface flow in Buckeye Creek to enter the cave, but the sources of two inflows identified in the cave are unknown (Dasher and Balfour, 1994). In addition to Buckeye Creek Cave and Spencer Cave, a number of other springs and insurgences have been documented in the basin. Known springs and insurgences are listed in Appendix $\mathbf{C}$.

\section{Rationale for Conducting the Study in Buckeye Creek Basin}

Buckeye Creek basin was chosen as the focus area for this study for several reasons. The basin is a manageable size for the scope of this analysis. Recharge in the basin is primarily autogenic and the catchment boundaries have been defined by previous studies (Price and Heck, 1939; Heller, 1980). Published and unpublished data also exist for Buckeye Creek and 
neighboring Hole Basin (Boyer and Pasquarell, 1999; Boyer, unpublished). Previous studies of the area and the physical attributes of size and autogenic recharge facilitated identification of the sources of contamination in the basin. Finally, Buckeye Creek basin is geographically central to the Greenbrier River Hydrologic Unit area of interest and shares similar agricultural contamination issues with many neighboring basins.

\section{Previous Studies and Existing Data}

Before the onset of this study, data existed for streams within Buckeye Creek basin and the neighboring basins. The first data set is the statewide Integrated Water Quality Assessment and Monitoring Report, which is fulfills the federal requirements of sections 305(b) and 303(d) of the Clean Water Act. The Division of Water and Waste Management of the WVDEP is responsible for issuing this biannual report, which at the time of data compilation was most recently approved in 2010 and includes causes of impairment for all streams identified in the 303(d) list of impaired streams (WVDEP, 2010). Additional data available for both 303(d) listed streams and 305(b) streams includes $\mathrm{pH}$, temperature, specific conductivity, dissolved oxygen, and fecal coliform density. In addition to the long-term ambient water quality monitoring system developed in the 1960s, WVDEP has also carried out probabilistic (random) sampling, targeted sampling in selected watersheds, and pre-TMDL development sampling (WVDEP, 2008). The WVDEP provided all available data for testing sites in Greenbrier County, summarized in Table

2. Relevant WVDEP data collected by all methods are compiled in Appendix A and were used to guide study design. The WVDEP recorded high FC densities in Spring Creek on several sample dates, providing an additional reason to study fecal coliform contamination in the area (Appendix A). 


\begin{tabular}{|c|c|c|c|c|c|c|c|}
\hline Site Name & $\begin{array}{l}\text { Basin } \\
\text { Name }\end{array}$ & Date Range & $\begin{array}{l}\text { Number } \\
\text { Sample } \\
\text { Dates } \\
\text { Included }\end{array}$ & $\begin{array}{l}\text { Mean } \\
\text { Temp } \\
\left({ }^{\circ} \mathrm{C}\right)\end{array}$ & $\begin{array}{l}\text { Mean Specific } \\
\text { Conductivity in } \\
\mu S / \mathrm{cm} \text { (range) }\end{array}$ & $\begin{array}{l}\text { Mean pH } \\
\text { (range) }\end{array}$ & $\begin{array}{l}\text { Mean Fecal } \\
\text { Coliforms in } \\
\text { CFU/100ml } \\
\text { (range) }\end{array}$ \\
\hline Milligan Creek & $\begin{array}{l}\text { Davis } \\
\text { Spring }\end{array}$ & $\begin{array}{l}\text { 07/99; } \\
\text { 06/04-05/05 }\end{array}$ & 12 & 12.19 & $\begin{array}{r}296 \\
(180-401) \\
\end{array}$ & $\begin{array}{r}8.03 \\
(7.45-8.39) \\
\end{array}$ & $\begin{array}{r}686 \\
(14-3450) \\
\end{array}$ \\
\hline Sinking Creek & $\begin{array}{l}\text { Sinking } \\
\text { Creek }\end{array}$ & 06/04-05/05 & 10 & 9.84 & $\begin{array}{r}102 \\
(65-184)\end{array}$ & $\begin{array}{r}7.51 \\
(7.00-7.82) \\
\end{array}$ & $\begin{array}{r}842 \\
(30-7600) \\
\end{array}$ \\
\hline Spring Creek & $\begin{array}{l}\text { Spring } \\
\text { Creek }\end{array}$ & $\begin{array}{l}07 / 99 ; \\
06 / 04-05 / 05\end{array}$ & 12 & 12.45 & $\begin{array}{r}150 \\
(113-201)\end{array}$ & $\begin{array}{r}7.71 \\
(7.12-8.38)\end{array}$ & $\begin{array}{r}615 \\
(2-4800)\end{array}$ \\
\hline $\begin{array}{l}\text { Culverson } \\
\text { Creek }\end{array}$ & $\begin{array}{l}\text { Culverson } \\
\text { Creek }\end{array}$ & 07/99-04/01 & 4 & 11.18 & $\begin{array}{r}174 \\
(120-263)\end{array}$ & $\begin{array}{r}7.52 \\
(7.18-7.73)\end{array}$ & $\begin{array}{r}320 \\
\text { (measured for } \\
\text { one date) }\end{array}$ \\
\hline Beverly Fork & $\begin{array}{l}\text { Spring } \\
\text { Creek }\end{array}$ & 06/04-05/05 & 11 & 9.19 & $\begin{array}{r}66 \\
(51-96)\end{array}$ & $\begin{array}{r}7.43 \\
(6.02-8.46)\end{array}$ & $\begin{array}{r}149 \\
(2-1550)\end{array}$ \\
\hline Locust Creek & $\begin{array}{l}\text { Locust } \\
\text { Creek }\end{array}$ & 07/99; 09/07 & 2 & 18.33 & $\begin{array}{r}286 \\
(257-315)\end{array}$ & $\begin{array}{r}8.08 \\
\text { (measured } \\
\text { for one date) }\end{array}$ & $\begin{array}{r}245 \\
\text { (measured for } \\
\text { one date) }\end{array}$ \\
\hline Burns Run & $\begin{array}{l}\text { Culverson } \\
\text { Creek }\end{array}$ & $10 / 07$ & 1 & 13.32 & $234(N / A)$ & $6.98(N / A)$ & Not Tested \\
\hline
\end{tabular}

Table 2: Summary of WVDEP water quality data available for sites within the Greenbrier River

Watershed (WVDEP, 2010).

Doug Boyer of the USDA Agricultural Research Service (ARS) provided a second source of data collected prior to this study, summarized in Table 3. The data include samples from Buckeye Creek (Boyer, unpublished) and The Hole basins (Boyer and Kuczynska, 2003; Boyer and Pasquarell, 1996; Pasquarell and Boyer, 1995). Complete USDA data are included in

\section{Appendix B.}




\begin{tabular}{|l|l|l|r|r|r|r|r|}
\hline Site Name & $\begin{array}{l}\text { Basin } \\
\text { Name }\end{array}$ & Date Range & $\begin{array}{r}\text { Number of } \\
\text { Sample } \\
\text { Dates } \\
\text { Included }\end{array}$ & $\begin{array}{r}\mathbf{N O}_{3}^{-} \\
(\mathbf{m g} / \mathbf{L})\end{array}$ & $\begin{array}{r}\mathrm{Ca}^{2+} \\
\text { (mg/L) }\end{array}$ & $\begin{array}{r}\mathbf{M g}^{2+} \\
\text { (mg/L) }\end{array}$ & $\begin{array}{r}\text { Mean Fecal } \\
\text { Coliforms } \\
\text { (CFU/100ml) }\end{array}$ \\
\hline BCC Entrance & $\begin{array}{l}\text { Buckeye } \\
\text { Creek }\end{array}$ & $09 / 02-11 / 03$ & 34 & 0.55 & 29.14 & 3.22 & 679 \\
\hline BCC Upstream & $\begin{array}{l}\text { Buckeye } \\
\text { Creek }\end{array}$ & $09 / 02-11 / 03$ & 29 & 0.56 & 29.04 & 3.24 & 739 \\
\hline $\begin{array}{l}\text { BCC } \\
\text { Downstream }\end{array}$ & $\begin{array}{l}\text { Buckeye } \\
\text { Creek }\end{array}$ & $08 / 00-05 / 02$ & 17 & 0.69 & 31.74 & 3.10 & 143 \\
\hline Burn's Cave* & $\begin{array}{l}\text { Culverson } \\
\text { Creek }\end{array}$ & $06 / 90-01 / 09$ & 742 & 2.81 & 49.10 & 6.70 & 2387 \\
\hline
\end{tabular}

* Samples from this location contain storm runoff samples collected by autosampler, and thus would be expected to represent significantly higher peaks in FC concentrations.

Table 3: Summary of available USDA-ARS Water Quality Data for sites within the Greenbrier Hydrologic Unit (Boyer and Kuczynska, 2003; Boyer and Pasquarell, 1996; Pasquarell and Boyer, 1995; Boyer, unpublished).

The USDA ARS data from The Hole basin were collected from Burn's Cave, the main resurgence to Spring Creek, and therefore represent the major potential source of contamination coming from that basin. The USDA data from Buckeye Creek were collected from several points within Buckeye Creek Cave, which contains the main runoff from Buckeye Creek basin. Thus, because the cave receives inflow from multiple conduits, the data represent a collection of several contamination sources from within the basin, possibly including drainage from springs not directly sampled in this study.

\section{Methods}

\section{Data Collection}

Water temperature can indicate how much contribution a spring is receiving from surface water relative to ground water in karst aquifers with rapid flow. The range of temperatures in a 
karst system during a rainfall runoff event can show if surface water is likely to generate variations in spring water quality (Mahler et al., 2000). Onset HOBO Pendant 64K temperature loggers were placed at selected springs in the basin during the preliminary phase of data collection to provide insight into the influences of groundwater and surface water on these springs. Data loggers were placed at Apple Spring, Circulating Cenote, the Buckeye Creek Cave entrance, Spencer Resurgence, and an unnamed spring in the southwest part of the study basin. All of these sites also were included in further water quality sampling except for the Circulating Cenote, which receives water from outside of Buckeye Creek basin. The temperature data collection sites were selected primarily because of the ability to install the submergible data loggers at each of the locations. Temperature data loggers could not be installed at sites where baseflow discharge was insufficient to completely submerse the loggers or where baseflow mainly seeped from rocks without forming a channel or pool. The sites were also chosen so that a range of sources with varying proportions of groundwater and surface water would be represented.

Water temperature was measured at 10 minute intervals. Rainfall and ambient temperature data representative of the basin were collected at the NOAA weather station in Renick, West Virginia $\left(37^{\circ} 59^{\prime} \mathrm{N} 80^{\circ} 22^{\prime} \mathrm{W}\right)$, approximately $3.3 \mathrm{~km}(2.1 \mathrm{mi})$ northeast of the boundary of the basin. Rainfall totals at Renick were reported daily. Data from the HOBO loggers were downloaded twice during the study using HOBOware Pro software and exported to Microsoft Excel spreadsheets for analysis. The temperature logs were analyzed for change during rainfall events. For this purpose, a "rainfall event" was defined as any event or series of events that results in $1 \mathrm{~cm}$ or more of rain within a 24-hour period. Snowfall events may not 
immediately affect the spring flow; therefore, temperature logs were also analyzed for changes resulting from melting that occurred after a snowfall event.

Runoff during rain events can cause significant, rapid changes in groundwater quality in karst springs and streams (Ashton, 1966). Fecal coliform and suspended sediment levels have both been shown to increase significantly after rain events (Ryan and Meiman, 1996). However, it has also been demonstrated that sampling only at peak flow is unreliable in karst springs (Ryan and Meiman, 1996). A flow-dependent sampling strategy is needed for samples to be truly representative of differences in water quality during runoff events. In order to obtain the most representative samples possible in the given timeframe, springs were sampled multiple times at baseflow conditions. Baseflow samples were taken following a period of little or no precipitation. All of the samples were taken after a period of at least 48 hours with less than 0.6 $\mathrm{cm}$ rainfall in the area. Baseflow samples from all sites were taken on the same day so that conditions were comparable. One storm flow sample was also taken during the course of the study in order to test for a difference between baseflow and storm flow water quality variables. Ideally, additional rain event samples would have been taken during or within 24 hours of multiple rainfall events to obtain information about how different rates and amounts of precipitation affect various water quality parameters, however, due to the limited scope and duration of this research, additional rain event sampling was not completed.

Seven springs located throughout the basin were identified for water quality sampling: Apple Spring, Raceway Spring West, Raceway Spring East, Upper Buckeye Creek Spring, Buckeye Creek Cave Entrance, Spencer Resurgence, and an unnamed spring (Appendix D). Upper Buckeye Creek Spring flows directly into the entrance of Buckeye Creek Cave after approximately 305 meters (1000 ft) of surface valley. During low flow this is the only surface 
water input into Buckeye Creek Cave. During wetter times, Buckeye Creek flows in its surface channel and joins water from Upper Buckeye Creek Spring before entering the cave. Buckeye Creek continues to flow through the stream level of Buckeye Creek Cave for over $1750 \mathrm{~m}$ (5800 ft) before exiting at the Spencer Resurgence and flowing directly into Spring Creek (Dasher and Balfour, 1994). Sampling was terminated at Raceway Spring East when it was found to have significant flow only during wet periods and insufficient baseflow for sampling.

Sites were sampled according to United States Geological Survey (USGS) water sampling guidelines (U.S. Geological Survey, 2008). Water at each site was tested in the field for physical and chemical parameters including temperature, $\mathrm{pH}$, and specific conductivity. These variables were measured in situ using Hannah Instruments handheld $\mathrm{pH}$ and specific conductivity meters. Samples for fecal coliform bacteria were tested in the West Virginia University Division of Plant and Soil Sciences microbiology laboratory in Morgantown, West Virginia. Samples for nitrate, magnesium, and calcium concentration were filtered and tested following USGS guidelines at the USDA-ARS Research Laboratory in Beaver, West Virginia using ion chromatography.

Samples to be tested for fecal coliform bacteria were collected in autoclave-sterilized containers and held on ice in a cooler until analysis. These samples were analyzed for fecal coliform bacteria density using membrane filtration within 8 hours of collection. The standard membrane filtration procedure for enumerating fecal coliforms was followed and aseptic techniques were used (American Public Health Association, 1992). Samples were filtered using a Millipore $0.45-\mu \mathrm{m}$ porosity membrane filter. Volumes of 1,10 , and $100 \mathrm{ml}$ were filtered separately for each test site. The use of multiple sample volumes allows for accurate enumeration of FC colonies even in samples that contain very small or large numbers of fecal 
coliforms (Dufour et al., 1981). The filters were then placed in sterile plastic plates containing commercially prepared standard m-Fecal Coliform (m-FC) medium. The plates were incubated at $44.5 \pm 0.2^{\circ} \mathrm{C}\left(112.1^{\circ} \mathrm{F}\right)$ for $24 \pm 1$ hours. This incubation temperature specifically selects fecal coliform bacteria, while preventing growth of other background coliform bacteria. Colonies on each filter were counted after the 24-hour incubation period. Sample volumes that yielded 20-80 colonies per membrane filter were considered most accurate. The sample volume from each collection site that yielded a number of colonies within this range was used to calculate fecal coliform density in colony-forming units per $100 \mathrm{ml}(\mathrm{CFU} / 100 \mathrm{ml})$ for that site. If all samples were outside of the acceptable range, USGS guidelines were followed to calculate CFU/100 ml for that particular situation by either using the plate with the closest count to the acceptable range if all counts fell on one side of the range, and averaging the closest counts above and below the range if some fell over and some fell under the acceptable range (U.S. Geological Survey 2008).

Samples were also analyzed for nitrate concentration and calcium and magnesium concentration. Samples for nitrate, calcium, and magnesium testing were collected separately from FC samples and filtered through $0.45-\mu \mathrm{m}$ filters upon return to the lab and then refrigerated until analysis. Nitrate, calcium, and magnesium ion concentrations were measured using suppressed ion chromatography. Finally, separate samples were analyzed in the lab for alkalinity. These samples were collected in sample bottles with no air space and kept on ice until analysis. Alkalinity samples were all analyzed using digital titration with $1.6 \mathrm{~N} \mathrm{H}_{2} \mathrm{SO}_{4}$ within 24 hours of collection (U.S. Geological Survey 2008).

Data precision for fecal coliform, nitrate, and calcium and magnesium testing was evaluated by duplicating the samples from at least one collection site for each sample date. 
Accuracy of ion concentration data was evaluated by testing samples with known standard concentrations of each measured parameter. Quality control results are given in Appendix G.

In order to calculate total contaminant loading, or flux, it is also critical to know the discharge of springs or streams from which samples are collected. However, discharge can be difficult to measure precisely in this field area. Streams or springs in this basin often come from underground sources with indefinite or difficult to measure cross-sectional areas, and may resurge without forming a discernible channel. In other cases in this basin, water seeps from springs into a surface channel and flow cannot be measured accurately. Because of the differences in flow rates and spring outlets, a variety of discharge measurement methods were required. The most appropriate measurement method was determined for each spring or stream on an individual basis.

For Raceway Spring West, a spring with low flow and a single main discharge point, discharge was measured by time required to fill a $1000 \mathrm{ml}$ container and then converting this measurement to $\mathrm{ft}^{3} / \mathrm{s}$ and $\mathrm{m}^{3} / \mathrm{s}$. For streams or springs that form a surface channel before sinking or entering another stream, discharge was determined by measuring the cross-sectional area and average flow velocity and multiplying these to calculate discharge. This method was used for Apple Spring, Upper Buckeye Creek Spring, Buckeye Creek Cave entrance, Spencer Resurgence, and the unnamed spring.

When discharge is unknown or cannot be precisely measured, other water quality variables from a spring may be used as a "proxy" or as an alternative indicator of discharge. In this case, $\mathrm{Ca}^{2+}$ and $\mathrm{Mg}^{2+}$ concentrations measured in the samples were used as an additional indicator of discharge. The concentration of dissolved calcium and magnesium varies with 
discharge in karst springs, but also varies by location and by aquifer type (Shuster and White, 1971). Typically, as stormflow increases, mineral concentration decreases as "new" water enters the karst aquifer. This relationship may be used to show variation in discharge relative to another sample from the same spring. In this study, $\mathrm{Ca}^{2+}$ and $\mathrm{Mg}^{2+}$ levels were measured for each site to provide data that could be used as a secondary indicator of discharge. After discharge for each sample site was determined, it was then multiplied by the fecal coliform density of the stream or spring to identify the site's total FC loading amount, or flux, at the time of sampling, and this flux value was used to determine its relative contribution to watershed contamination.

Finally, GIS data were collected to produce map products used in the assessment of potential BMP placement locations. All GIS analysis was completed using ESRI ArcGIS (Version 9.3.1) software. Groundwater flow in the basin was mapped using pre-existing dye trace studies. A land use map was also created based on existing GIS data, field observations, and farm management plans on file for the area from the NRCS. A map of karst agricultural land was created from the land use and geologic maps to show all pasture and crop land use areas that occur over limestone bedrock. To create this map, the geologic polygons were first converted to $30 \mathrm{~m}$ raster cells. Then pixel values were reclassified in the $30 \mathrm{~m}$ Land Use/Land Cover (LULC) data set as " 1 ” for pasture or crop land and " 0 " for all other land uses. The geologic map was reclassified as "karst" and "non-karst" by setting values for all Greenbrier Group formations (possible karst) as "1" and all other formations (karst development unlikely) as "0". To identify karst agricultural land, the reclassified geologic map was then multiplied by the reclassified land use map so that all karst agriculture land resulted in pixel values of " 1 " and everything else resulted in " 0 ". 
Karst groundwater flow, and therefore groundwater contamination, is spatially discontinuous and unpredictable. Thus, groundwater contamination in karst areas is not easily interpolated by conventional contaminant spread models (Ryan and Meiman, 1996). Because of this difficulty, karst hydrology models need to be specific to the basin. In order to place BMPs in the most critical contaminant source areas, the source areas needed to be identified by their connection to contaminated sample sites. In addition to the known connections mapped on the groundwater basin map, GIS-based models were developed to identify additional source areas that could potentially be contaminating groundwater and surface water in Buckeye Creek basin.

Potential contamination source areas were identified using Digital Elevation Model (DEM) data (U.S. Geological Survey, 2006), land use data from the 2001 National Land Cover Database (U.S. Geological Survey Land Cover Institute, 2001), and geologic polygon data digitized from field studies (Heller, 1980; J. Tudek, unpublished).

The models used to identify these potential contamination source areas include defining subwatersheds for each sample site and estimating the groundwater surface elevation. The subwatersheds in the basin were defined based on surface elevation, using the DEM and USGS topographic contours. Subwatersheds were delineated to estimate the area of the watershed that contributes surface runoff to each site (Barfield, et al., 2004). Subwatersheds were identified by manually digitizing the watershed boundaries based on the elevation data.

Surface runoff flow direction was determined from a 10 m DEM using the ArcGIS Flow Direction function. The ArcGIS Watershed function was also tested as a method to model subwatersheds, but found inadequate. To use the Watershed function, a flow accumulation map was developed and sample sites were moved to the cell of highest accumulation within $100 \mathrm{~m}$ 
proximity. Points were moved to cells of higher accumulation because observations show that it is common for karst features in the area to actually capture the entire surface drainage during base flow conditions. ArcGIS cannot recognize this accumulation unless the sample point is located directly in the apparent surface flow path. Subwatershed outlet points were defined at each sample site in order to find the contributing drainage area for each sample site (Barfield, et al., 2004). However, precise results could not be obtained using the Watershed function because of the small watershed areas and irregular elevations of the karst terrain.

As an alternative to the Watershed function, subwatersheds also were created for each sample point by manually digitizing boundaries using the $10 \mathrm{~m}$ DEM and $20 \mathrm{ft}$ contour lines (U.S. Geological Survey, 2006). The manual model was judged more accurate because the subwatershed dimensions are more consistent with published and first-hand field observations of storm runoff flow.

A third model used to represent basin hydrology involved estimating the groundwater (water table) surface in order to identify groundwater flow direction within the basin. The groundwater surface between springs was estimated by kriging, a statistically-based interpolation method that uses regionalized variable theory to estimate values, between a set of known sample points (Bolstad 2008). Springs were used as points for kriging because each represents a known elevation on the groundwater surface. This interpolation method may be somewhat limited in a karst system. For example, this model does not account for seasonal changes in water table elevation, which may cause water to move through different flow paths at different times of year. In addition, the model does not account for the subsurface flow through Buckeye Creek Cave, except for the inclusion of the elevation of the discharge point at Spencer Resurgence. The cave system and other large conduits likely create changes in the potentiometric surface that are not 
detected by using spring elevations alone. Despite the limitations, this model was tested to determine if it could predict flow directions similar to the known connections or correctly predict relative high and low regions of the groundwater surface.

Because they were created using surface DEM data, the map produced using the manually digitized subwatershed model reflects the contributing drainage area for surface runoff into each sample point. The groundwater map showing connections confirmed by dye tracing and the groundwater surface map produced by Kriging both reflect the contributing subsurface drainage area for each sample site. These three maps were examined and compared to identify possible contamination source areas for each sample site.

\section{Data Analysis}

Fecal coliform bacteria counts and nitrate concentrations from all samples were compared statistically for each sampling site. Statistics were calculated using JMP 9 statistics software. Basic descriptive statistics including mean, median, and standard deviation were calculated for each site for both fecal coliform densities and nitrate concentrations. Ordinarily, each of these sites would be tested for normal distribution of the samples using the Shapiro-Wilk test. However, the sample size was too small to determine with certainty if the data are normally distributed, and they are not expected to be normally distributed. Studies with larger numbers of samples have shown non-normal distribution in stream and spring water quality data for karst areas (Boyer, 2008; Boyer and Kuczynska, 2003; Boyer and Pasquarell, 1999). Therefore, since the Shapiro-Wilk test could not be used, it was assumed that the data are not normally distributed and nonparametric statistical tests were used. The Kruskal-Wallis test can be used as a 
nonparametric alternative to analysis of variance. The Kruskal-Wallis test was used to test for a significant difference between the sampling locations for FC and nitrate levels.

Tests of correlation also were used to determine the relationships between water quality variables. A standard correlation such as Pearson's correlation coefficient (r) can be calculated for bivariate normal data, but when data are not assumed to be normal, a nonparametric alternative, such as Spearman's rank correlation coefficient, must be used. In this study, correlations were examined using Spearman's rank correlation coefficient for nitrate and fecal coliform levels, as well as for fecal coliform levels and calcium and magnesium levels. It was expected that fecal coliform levels and nitrate levels would be positively correlated because they are both related to agricultural contamination. Correlation was also examined for discharge and FC and nitrate levels. It was expected that despite dilution, FC and nitrate levels would actually be positively correlated with discharge because increased runoff has been found to increase contaminant levels in karst springs (Ryan and Meiman, 1996). Correlations were determined for these relationships for each sampling site separately and for the basin as a whole. Because of the small number of samples collected for this study, it was expected that the basin-wide tests might show a significant correlation in the watershed that might be missed by only looking at a single sampling site.

Temperature logs were analyzed for changes in water temperature immediately before, during, and after rainfall events as indicated by NOAA precipitation data. Any significant temperature changes were noted and analyzed for correlation with precipitation data to determine if a relationship exists between water temperature change and precipitation. Relationships between temperature and precipitation could be used to help understand the relative contributions of groundwater and surface water during rainfall events for each sampling site. These 
relationships were not tested under the scope of this research, but were used to provide additional information about the potential sources of contamination at the sampling sites.

\section{Results}

\section{Sampling Data}

\section{Precipitation and Temperature}

Eighteen different significant precipitation events (24-hour period with $\geq 1 \mathrm{~cm}$

precipitation) were recorded during this study (Table 4). If additional precipitation was recorded in the 24-hour period immediately preceding or following, this was added to the precipitation total for the significant precipitation event. Precipitation intensity was calculated by dividing the total precipitation by the number of consecutive days that were included in the event. NOAA precipitation is given in water equivalent, so precipitation that fell as snow in some of these significant precipitation events may not have actually contributed to the watershed as water until after melting days later. 


\begin{tabular}{|c|c|c|c|}
\hline Precipitation Events & $\begin{array}{r}\text { Daily Precipitation } \\
\text { (cm water equivalent) }\end{array}$ & Event Total $(\mathrm{cm})$ & Intensity (cm/day) \\
\hline $7 / 18 / 2010$ & 0.33 & & \\
\hline $7 / 19 / 2010$ & 1.32 & & \\
\hline $7 / 20 / 2010$ & 0.53 & & \\
\hline $7 / 21 / 2010$ & 2.34 & & \\
\hline $7 / 22 / 2010$ & 0.13 & 4.65 & 0.93 \\
\hline $7 / 26 / 2010$ & 2.51 & 2.51 & 2.51 \\
\hline $8 / 1 / 2010$ & 3.10 & 3.10 & 3.10 \\
\hline $8 / 19 / 2010$ & 1.55 & 1.55 & 1.55 \\
\hline $8 / 24 / 2010$ & 0.46 & & \\
\hline $8 / 25 / 2010$ & 1.40 & & \\
\hline $8 / 26 / 2010$ & 0.10 & 1.96 & 0.65 \\
\hline $9 / 27 / 2010$ & 1.73 & & \\
\hline $9 / 28 / 2010$ & 2.87 & 4.60 & 2.30 \\
\hline $10 / 27 / 2010$ & 1.40 & & \\
\hline $10 / 28 / 2010$ & 0.51 & 1.91 & 0.95 \\
\hline $11 / 4 / 2010$ & 1.68 & & \\
\hline $11 / 5 / 2010$ & 0.84 & & \\
\hline *11/6/2010 & 0.15 & 2.67 & 0.89 \\
\hline $11 / 30 / 2010$ & 0.76 & & \\
\hline$* 12 / 1 / 2010$ & 3.96 & 4.72 & 2.36 \\
\hline$* 12 / 12 / 2010$ & 0.28 & & \\
\hline *12/13/2010 & 1.14 & & \\
\hline$* 12 / 14 / 2010$ & 0.15 & 1.57 & 0.52 \\
\hline$* 12 / 17 / 2010$ & 1.65 & 1.65 & 1.65 \\
\hline$* 1 / 27 / 2011$ & 2.26 & & \\
\hline *1/28/2011 & 0.18 & & \\
\hline *1/29/2011 & 0.13 & 2.57 & 0.86 \\
\hline$* 2 / 2 / 2011$ & 1.52 & 1.52 & 1.52 \\
\hline $2 / 25 / 2011$ & 1.78 & & \\
\hline$* 2 / 26 / 2011$ & 0.23 & 2.01 & 1.00 \\
\hline $2 / 28 / 2011$ & 0.08 & & \\
\hline *3/1/2011 & 1.98 & 2.06 & 1.029 \\
\hline *3/6/2011 & 4.45 & & \\
\hline *3/7/2011 & 1.83 & 6.27 & 3.14 \\
\hline $3 / 10 / 2011$ & 2.74 & & \\
\hline$* 3 / 11 / 2011$ & 1.42 & 4.16 & 2.08 \\
\hline $3 / 24 / 2011$ & 1.57 & 1.57 & 1.57 \\
\hline $4 / 5 / 2011$ & 2.21 & & \\
\hline$* 4 / 6 / 2011$ & 0.08 & 2.29 & 1.14 \\
\hline 4/9/2011 & 1.27 & & \\
\hline
\end{tabular}




\begin{tabular}{|c|c|c|c|}
\hline $4 / 10 / 2011$ & 1.93 & 3.20 & 1.60 \\
\hline $4 / 12 / 2011$ & 0.76 & & \\
\hline $4 / 13 / 2011$ & 2.13 & 2.90 & 1.45 \\
\hline $4 / 16 / 2011$ & 0.18 & & \\
\hline $4 / 17 / 2011$ & 1.52 & 1.70 & 0.85 \\
\hline $4 / 23 / 2011$ & 1.88 & 1.88 & 1.88 \\
\hline $4 / 25 / 2011$ & 0.08 & & \\
\hline $4 / 26 / 2011$ & 1.07 & & \\
\hline $4 / 27 / 2011$ & 0.18 & & \\
\hline $4 / 28 / 2011$ & 2.84 & & \\
\hline $4 / 29 / 2011$ & 0.20 & 4.37 & 0.87 \\
\hline
\end{tabular}

Table 4: Rainfall and ambient temperature data for the basin were collected at the NOAA

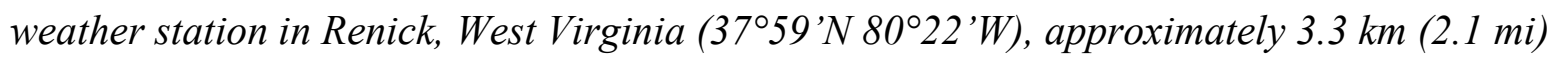
northeast of the northern boundary of the basin. Rainfall totals were reported daily in water equivalents. *Indicates low temperature below freezing, possible snowfall events.

Temperature was plotted over time at two sampling sites during and after the three largest events by total precipitation (Figure 6). Ambient temperature data from Renick, West Virginia, were plotted in order to interpret what effect surface runoff might have on the spring water temperature. Greenbrier River discharge data from the nearest downstream USGS gage in Alderson, West Virginia, were included to determine when the precipitation event affected surface runoff. 

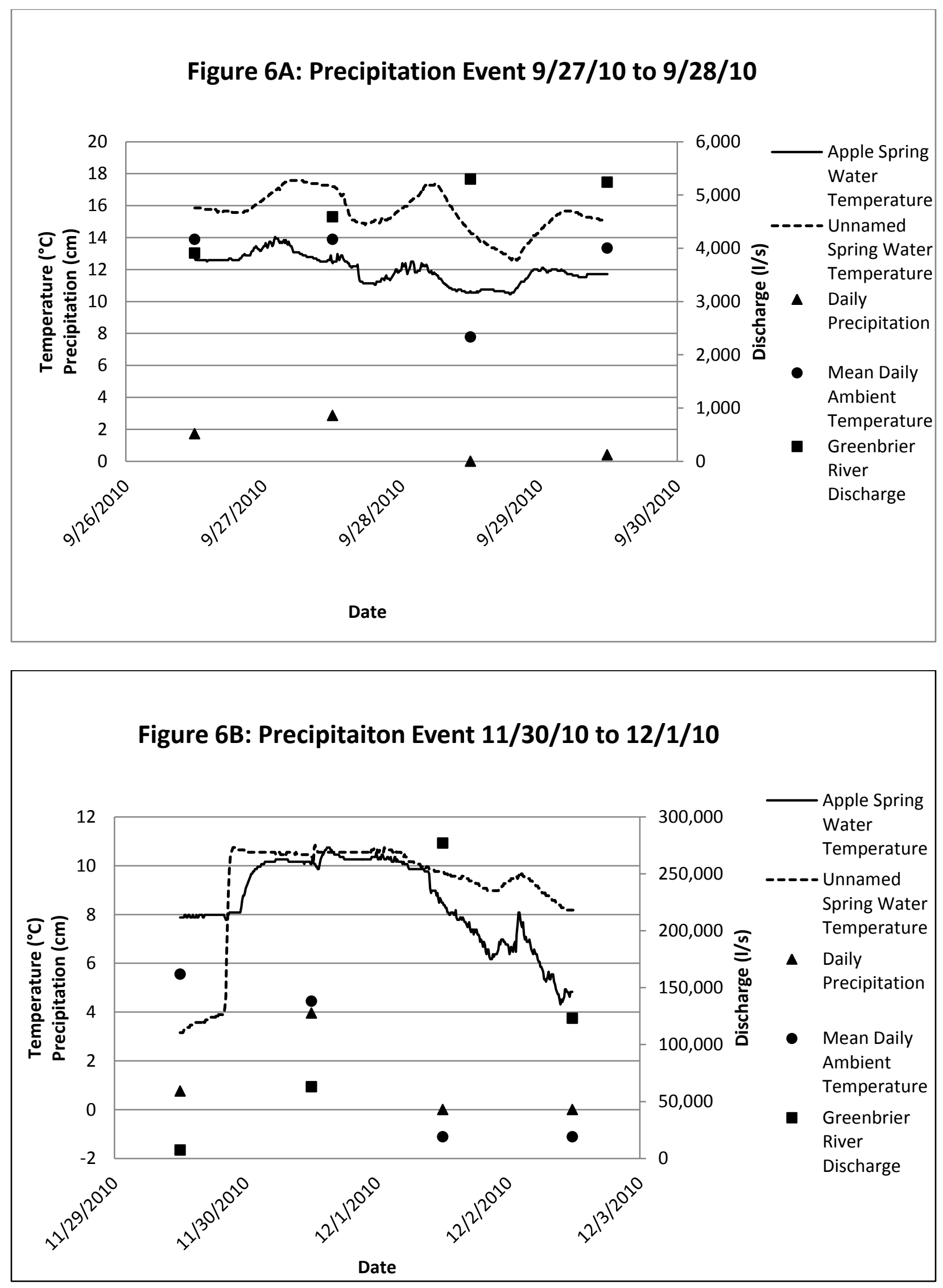


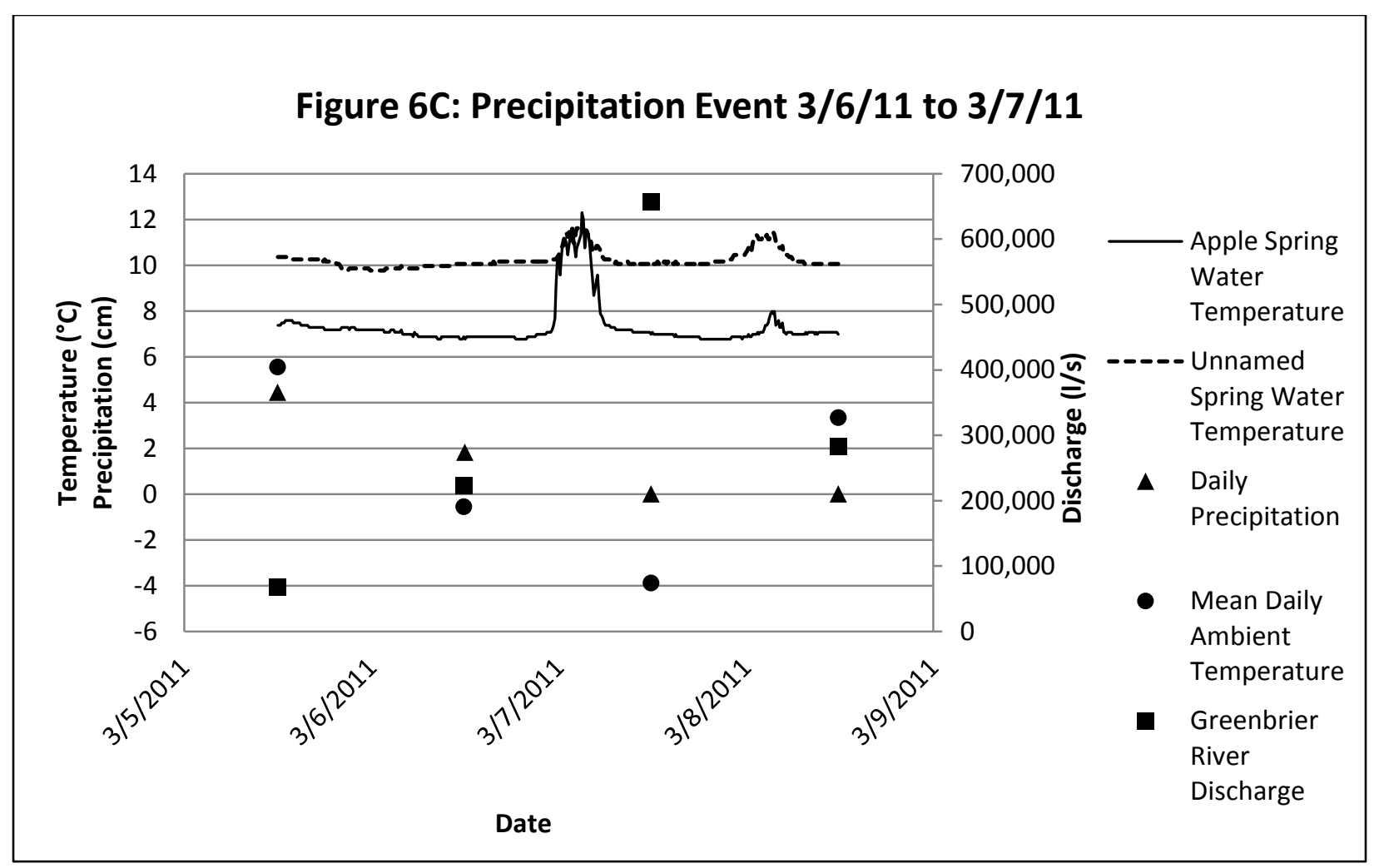

Figure 6: Change in spring water temperature with precipitation in Apple Spring and Unnamed Spring for three different precipitation events. Greenbrier River discharge was measured at USGS gage 03183500 in Alderson, WV. (US Geologic Survey, 2011).

\section{Water Quality Results}

Water samples were collected on seven different dates from September 2010 to April 2011. These included two fall dates: September $16^{\text {th }}$ and September $23^{\text {rd }}, 2010$; three winter dates: January $19^{\text {th }}$, January $24^{\text {th }}$, and January $31^{\text {st }}, 2011$; and two spring dates: April $18^{\text {th }}$ and April $28^{\text {th }}, 2011$. Variables measured included FC concentration, discharge, nitrate concentration, calcium concentration, magnesium concentration, FC loading, nitrate loading, and alkalinity (Table 5). 


\begin{tabular}{|c|c|c|c|c|c|c|c|c|}
\hline \multirow[b]{2}{*}{ Location } & \multirow[b]{2}{*}{ Season } & \multirow[b]{2}{*}{ Date } & \multicolumn{6}{|c|}{ Measured Variables } \\
\hline & & & $\begin{array}{c}\text { FC } \\
\text { concentration }\end{array}$ & Discharge & $\begin{array}{c}\mathrm{NO}_{3} \\
\text { concentration }\end{array}$ & Alkalinity & $\begin{array}{c}\mathrm{FC} \text { and } \mathrm{NO}_{3} \\
\text { loading }\end{array}$ & $\begin{array}{c}\mathrm{Ca} \text { and } \mathrm{Mg} \\
\text { concentration }\end{array}$ \\
\hline \multirow{7}{*}{$\begin{array}{l}\text { Apple } \\
\text { Spring }\end{array}$} & \multirow{2}{*}{ Fall } & $9 / 16 / 2010$ & $\mathrm{x}$ & & $\mathrm{X}$ & & & $\mathrm{X}$ \\
\hline & & $9 / 23 / 2010$ & $x$ & & $\mathrm{x}$ & & & $x$ \\
\hline & \multirow{3}{*}{ Winter } & $1 / 19 / 2011$ & $x$ & $x$ & $x$ & & $\mathrm{x}$ & $x$ \\
\hline & & $1 / 24 / 2011$ & $x$ & $\mathrm{x}$ & $\mathrm{x}$ & $x$ & $\mathrm{x}$ & $x$ \\
\hline & & $1 / 31 / 2011$ & $x$ & $x$ & $\mathrm{X}$ & $\mathrm{X}$ & $\mathrm{x}$ & $\mathrm{x}$ \\
\hline & \multirow{2}{*}{ Spring } & $4 / 18 / 2011$ & $x$ & $x$ & $x$ & $x$ & $x$ & $x$ \\
\hline & & $4 / 28 / 2011$ & $x$ & $x$ & $x$ & $x$ & $x$ & $x$ \\
\hline \multirow{7}{*}{$\begin{array}{c}\text { Raceway } \\
\text { Spring } \\
\text { West }\end{array}$} & \multirow{2}{*}{ Fall } & $9 / 16 / 2010$ & $x$ & & $x$ & & & $x$ \\
\hline & & $9 / 23 / 2010$ & $x$ & & $x$ & & & $x$ \\
\hline & \multirow{3}{*}{ Winter } & $1 / 19 / 2011$ & $x$ & $\mathrm{x}$ & $x$ & & $x$ & $x$ \\
\hline & & $1 / 24 / 2011$ & $\mathrm{X}$ & $x$ & $\mathrm{x}$ & $\mathrm{x}$ & $x$ & $\mathrm{x}$ \\
\hline & & $1 / 31 / 2011$ & $x$ & $x$ & $x$ & $x$ & $x$ & $x$ \\
\hline & \multirow{2}{*}{ Spring } & $4 / 18 / 2011$ & $\mathrm{x}$ & $\mathrm{x}$ & $\mathrm{x}$ & $\mathrm{x}$ & $\mathrm{x}$ & $\mathrm{x}$ \\
\hline & & $4 / 28 / 2011$ & $x$ & $x$ & $\mathrm{x}$ & $\mathrm{X}$ & $\mathrm{x}$ & $\mathrm{x}$ \\
\hline \multirow{7}{*}{$\begin{array}{c}\text { Upper } \\
\text { Buckeye } \\
\text { Creek } \\
\text { Spring }\end{array}$} & \multirow{2}{*}{ Fall } & 9/16/2010 & $x$ & & $x$ & & & $x$ \\
\hline & & $9 / 23 / 2010$ & $x$ & & $x$ & & & $x$ \\
\hline & \multirow{3}{*}{ Winter } & $1 / 19 / 2011$ & $x$ & $\mathrm{x}$ & $\mathrm{x}$ & & $\mathrm{x}$ & $\mathrm{x}$ \\
\hline & & $1 / 24 / 2011$ & $x$ & $x$ & $x$ & $\mathrm{x}$ & $x$ & $x$ \\
\hline & & $1 / 31 / 2011$ & $x$ & $x$ & $x$ & $x$ & $x$ & $x$ \\
\hline & \multirow{2}{*}{ Spring } & $4 / 18 / 2011$ & $x$ & $x$ & $x$ & $x$ & $x$ & $x$ \\
\hline & & $4 / 28 / 2011$ & $x$ & $x$ & $x$ & $x$ & $x$ & $x$ \\
\hline \multirow{7}{*}{$\begin{array}{l}\text { Unnamed } \\
\text { Spring }\end{array}$} & \multirow{2}{*}{ Fall } & $9 / 16 / 2010$ & $x$ & & $x$ & & & $x$ \\
\hline & & $9 / 23 / 2010$ & $x$ & & $\mathrm{x}$ & & & $\mathrm{X}$ \\
\hline & \multirow{3}{*}{ Winter } & $1 / 19 / 2011$ & $x$ & $x$ & $\mathrm{X}$ & & $x$ & $x$ \\
\hline & & $1 / 24 / 2011$ & $x$ & $x$ & $x$ & $x$ & $x$ & $x$ \\
\hline & & $1 / 31 / 2011$ & $x$ & $x$ & $\mathrm{X}$ & $\mathrm{X}$ & $\mathrm{x}$ & $\mathrm{X}$ \\
\hline & \multirow{2}{*}{ Spring } & $4 / 18 / 2011$ & $x$ & $x$ & $x$ & $x$ & $x$ & $x$ \\
\hline & & $4 / 28 / 2011$ & $x$ & $x$ & $x$ & $x$ & $x$ & $x$ \\
\hline \multirow{5}{*}{$\begin{array}{c}\text { Buckeye } \\
\text { Creek Cave } \\
\text { Entrance }\end{array}$} & \multirow{3}{*}{ Winter } & $1 / 19 / 2011$ & $x$ & $x$ & $x$ & & $x$ & $x$ \\
\hline & & $1 / 24 / 2011$ & $\mathrm{X}$ & $x$ & $x$ & $x$ & $x$ & $x$ \\
\hline & & $1 / 31 / 2011$ & $x$ & $x$ & $\mathrm{X}$ & $\mathrm{X}$ & $x$ & $\mathrm{X}$ \\
\hline & \multirow{2}{*}{ Spring } & $4 / 18 / 2011$ & $x$ & $x$ & $\mathrm{X}$ & $\mathrm{X}$ & $\mathrm{x}$ & $\mathrm{X}$ \\
\hline & & $4 / 28 / 2011$ & $x$ & $\mathrm{x}$ & $x$ & $\mathrm{X}$ & $\mathrm{x}$ & $\mathrm{x}$ \\
\hline \multirow{5}{*}{$\begin{array}{c}\text { Spencer } \\
\text { Resurgence }\end{array}$} & \multirow{3}{*}{ Winter } & $1 / 19 / 2011$ & $x$ & $\mathrm{X}$ & $x$ & & $\mathrm{x}$ & $x$ \\
\hline & & $1 / 24 / 2011$ & $x$ & $x$ & $x$ & $x$ & $x$ & $x$ \\
\hline & & $1 / 31 / 2011$ & $x$ & $\mathrm{x}$ & $\mathrm{x}$ & $\mathrm{x}$ & $x$ & $x$ \\
\hline & & $4 / 18 / 2011$ & $x$ & $x$ & $x$ & $x$ & $x$ & $x$ \\
\hline & Spring & $4 / 28 / 2011$ & $x$ & $x$ & $x$ & $x$ & $x$ & $x$ \\
\hline
\end{tabular}

Table 5: Sampling and data collection schedule for the study. X indicates data were collected for the variable on the sample dates.

Fecal coliform concentrations in CFU/100 ml were determined for six baseflow dates and one storm flow date (Table 6). Storm flow fecal coliform concentrations are generally orders of 
magnitude larger than the baseflow values and, thus, are not included in the baseflow mean values.

\begin{tabular}{|c|c|c|c|c|c|c|c|c|}
\hline & $9 / 16 / 2010$ & $9 / 23 / 2010$ & $1 / 19 / 2011$ & $1 / 24 / 2011$ & $1 / 31 / 2011$ & $4 / 18 / 2011$ & $\begin{array}{r}\text { Baseflow } \\
\text { Mean }\end{array}$ & $4 / 28 / 2011^{*}$ \\
\hline $\begin{array}{l}\text { Apple } \\
\text { Spring }\end{array}$ & 15 & 4 & 5 & 3 & 11 & 9 & 8 & 1,100 \\
\hline $\begin{array}{l}\text { Raceway } \\
\text { West } \\
\text { Spring }\end{array}$ & 46 & 3 & 5 & 1 & 36 & 5 & 16 & 520 \\
\hline $\begin{array}{l}\text { Upper } \\
\text { Buckeye } \\
\text { Creek } \\
\text { Spring }\end{array}$ & 160 & 510 & 11 & 6 & 15 & 13 & 119 & 1,975 \\
\hline $\begin{array}{l}\text { Unnamed } \\
\text { Spring }\end{array}$ & 119 & 54 & 0 & 3 & 62 & 17 & 43 & 680 \\
\hline $\begin{array}{l}\text { Buckeye } \\
\text { Creek Cave } \\
\text { Entrance }\end{array}$ & - & - & 35 & 14 & 13 & 13 & 19 & 500 \\
\hline $\begin{array}{l}\text { Spencer } \\
\text { Resurgence }\end{array}$ & - & - & 2 & 1 & 12 & 10 & 6 & 640 \\
\hline
\end{tabular}

$* 4 / 28 / 2011$ is a storm flow sample and is not included in the baseflow mean.

Table 6: Sample fecal coliform concentration in CFU/100 ml.

Discharge data in $\mathrm{L} / \mathrm{s}$ was collected for the last five sample dates (Table 7). The storm runoff samples were taken on April $28^{\text {th }}, 2011$, the fourth of five days of rainfall, on a day with $2.84 \mathrm{~cm}$ of rainfall. Most of this rainfall occurred in the early morning hours from about $1 \mathrm{a} . \mathrm{m}$. to 6 a.m., and samples were taken between 8 a.m. and 10 a.m. Discharge was significantly greater at all sites following this storm event than on other sample dates. All baseflow discharge measurements on winter dates are less than the spring dates, due to increased runoff in the spring. The latest winter date, January 31, 2011, shows larger values compared to the previous two winter sample dates. No precipitation was recorded on the sample date or the prior day, although precipitation was recorded several days prior, when daily low temperatures were below freezing, so the relatively high discharges on January 31, 2011 may be due to snow melt. 


\begin{tabular}{|l|r|r|r|r|r|r|}
\hline & $1 / 19 / 2011$ & $\mathbf{1 / 2 4 / 2 0 1 1}$ & $\mathbf{1 / 3 1 / 2 0 1 1}$ & $\mathbf{4 / 1 8 / 2 0 1 1}$ & $\begin{array}{r}\text { Baseflow } \\
\text { Mean }\end{array}$ & $\mathbf{4} \mathbf{2 8 / 2 0 1 1 *}$ \\
\hline Apple & 16.0 & 19.0 & 85.0 & 99.0 & 55.0 & 250.0 \\
Spring & $(0.6)$ & $(0.7)$ & $(3.0)$ & $(3.5)$ & $(1.9)$ & $(9.0)$ \\
\hline Raceway & $<0.1$ & 0.3 & 0.2 & 0.5 & 0.3 & 2.0 \\
West & $(<0.1)$ & $(<0.1)$ & $(<0.1)$ & $(<0.1)$ & $(<0.1)$ & $(0.1)$ \\
Spring & & & & & & \\
\hline Upper & 5.7 & 5.7 & 170.0 & 570.0 & 190.0 & 1300.0 \\
Buckeye & $(0.2)$ & $(0.2)$ & $(6.0)$ & $(20.0)$ & $(6.60)$ & $(45.0)$ \\
Creek & & & & & & \\
Spring & 0.3 & 0.3 & 28.0 & 7.7 & 9.3 & 35.0 \\
\hline $\begin{array}{l}\text { Unnamed } \\
\text { Spring }\end{array}$ & $(<0.1)$ & $(<0.1)$ & $(1.0)$ & $(0.3)$ & $(0.3)$ & $(1.3)$ \\
\hline Buckeye & 8.5 & 7.1 & 140.0 & 750.00 & 230.0 & 1000.0 \\
Creek Cave & $(0.3)$ & $(0.3)$ & $(5.0)$ & $(26.0)$ & $(8.0)$ & $(36.0)$ \\
Entrance & 43.0 & 28.0 & 96.0 & 570.0 & 180.0 & 850.0 \\
\hline Spencer & $(1.5)$ & $(1.0)$ & $(3.4)$ & $(20.0)$ & $(6.5)$ & $(30.0)$ \\
Resurgence & & & & & \\
\hline
\end{tabular}

$* 4 / 28 / 2011$ is a storm flow sample and is not included in the baseflow mean.

Table 7: Spring discharge in $L / s\left(\right.$ and $\left.f t^{3} / s\right)$.

Fecal coliform concentration and discharge allowed calculation of total fecal coliform loading (CFU/s) to the watershed for each site at the time of sampling (Table 8). Loading values could be calculated only for sample dates on which the discharge was determined. 


\begin{tabular}{|l|r|r|r|r|r|r|}
\hline & $1 / 19 / 2011$ & $1 / 24 / 2011$ & $1 / 31 / 2011$ & $4 / 18 / 2011$ & $\begin{array}{r}\text { Baseflow } \\
\text { Mean }\end{array}$ & 4/28/2011* \\
\hline $\begin{array}{l}\text { Apple } \\
\text { Spring }\end{array}$ & 820 & 570 & 9,300 & 8,900 & 4,900 & $2,800,000$ \\
\hline $\begin{array}{l}\text { Raceway } \\
\text { West } \\
\text { Spring }\end{array}$ & 1 & 2 & 85 & 25 & 28 & 10,000 \\
\hline $\begin{array}{l}\text { Upper } \\
\text { Buckeye } \\
\text { Creek } \\
\text { Spring }\end{array}$ & 620 & 340 & 25,000 & 74,000 & 25,000 & $25,000,000$ \\
\hline $\begin{array}{l}\text { Unnamed } \\
\text { Spring }\end{array}$ & 0 & 8 & 18,000 & 1,300 & 4,700 & 240,000 \\
\hline $\begin{array}{l}\text { Buckeye } \\
\text { Creek Cave } \\
\text { Entrance }\end{array}$ & 3,000 & 990 & 18,000 & 97,000 & 30,000 & $5,100,000$ \\
\hline $\begin{array}{l}\text { Spencer } \\
\text { Resurgence }\end{array}$ & 850 & 280 & 12,000 & 57,000 & 17,000 & $5,400,000$ \\
\hline
\end{tabular}

$* 4 / 28 / 2011$ is a storm flow sample and is not included in the baseflow mean.

Table 8: Site fecal coliform loading in CFU/s.

Alkalinity was calculated in both milliequivalents and $\mathrm{mg} / \mathrm{L}$ as bicarbonate, $\mathrm{HCO}_{3}{ }^{-}$

(Table 9). Alkalinity was generally lower for the spring dates compared to the winter dates. This relationship is likely more related to changes in hydrology as the season changes rather than temperature. While a trend cannot be determined from the small number of samples available, the observed decrease from winter to spring was expected, due to the increase in discharge from mixed ground and surface water sources. 


\begin{tabular}{|c|c|c|c|c|c|}
\hline & $1 / 24 / 2011$ & $1 / 31 / 2011$ & $4 / 18 / 2011$ & $\begin{array}{r}\text { Baseflow } \\
\text { Mean }\end{array}$ & $4 / 28 / 2011^{*}$ \\
\hline $\begin{array}{l}\text { Apple } \\
\text { Spring }\end{array}$ & $\begin{array}{r}1.11 \\
(67.83)\end{array}$ & $\begin{array}{r}0.83 \\
(50.51)\end{array}$ & $\begin{array}{r}0.69 \\
(41.97)\end{array}$ & $\begin{array}{r}0.88 \\
(53.44)\end{array}$ & $\begin{array}{r}0.75 \\
(45.63)\end{array}$ \\
\hline $\begin{array}{l}\text { Raceway } \\
\text { West } \\
\text { Spring }\end{array}$ & $\begin{array}{r}2.53 \\
(154.21)\end{array}$ & $\begin{array}{r}2.53 \\
(154.21)\end{array}$ & $\begin{array}{r}1.01 \\
(61.61)\end{array}$ & $\begin{array}{r}2.02 \\
(123.34)\end{array}$ & $\begin{array}{r}0.75 \\
(45.628)\end{array}$ \\
\hline $\begin{array}{l}\text { Upper } \\
\text { Buckeye } \\
\text { Creek } \\
\text { Spring }\end{array}$ & $\begin{array}{r}2.57 \\
(156.65)\end{array}$ & $\begin{array}{r}2.57 \\
(156.65)\end{array}$ & $\begin{array}{r}1.17 \\
(71.49)\end{array}$ & $\begin{array}{r}2.10 \\
(128.26)\end{array}$ & $\begin{array}{r}1.19 \\
(72.71)\end{array}$ \\
\hline $\begin{array}{l}\text { Unnamed } \\
\text { Spring }\end{array}$ & $\begin{array}{r}3.62 \\
(220.70) \\
\end{array}$ & $\begin{array}{r}3.21 \\
(196.05) \\
\end{array}$ & $\begin{array}{r}1.05 \\
(64.17) \\
\end{array}$ & $\begin{array}{r}2.63 \\
(160.31) \\
\end{array}$ & $\begin{array}{r}2.40 \\
(146.77)\end{array}$ \\
\hline $\begin{array}{l}\text { Buckeye } \\
\text { Creek Cave } \\
\text { Entrance }\end{array}$ & $\begin{array}{r}2.85 \\
(173.85)\end{array}$ & $\begin{array}{r}2.73 \\
(166.53)\end{array}$ & $\begin{array}{r}1.47 \\
(90.04)\end{array}$ & $\begin{array}{r}2.35 \\
(143.47)\end{array}$ & $\begin{array}{r}1.56 \\
(94.92)\end{array}$ \\
\hline $\begin{array}{l}\text { Spencer } \\
\text { Resurgence }\end{array}$ & $\begin{array}{r}2.36 \\
(144.33)\end{array}$ & $\begin{array}{r}2.36 \\
(144.33)\end{array}$ & $\begin{array}{r}0.55 \\
(33.31)\end{array}$ & $\begin{array}{r}1.76 \\
(107.32)\end{array}$ & $\begin{array}{r}1.45 \\
(88.82)\end{array}$ \\
\hline
\end{tabular}

$* 4 / 28 / 2011$ is a storm flow sample and is not included in the baseflow mean.

Table 9: Sample alkalinity in meq/L (and $\mathrm{mg} / \mathrm{L}_{\text {as }} \mathrm{HCO}_{3}^{-}$).

Nitrate concentrations were generally lower in spring than in fall or winter (Table 10).

Lower nitrate concentrations in the spring may be due to increased discharge diluting the nitrate, also supported by the fact that nitrate concentrations in storm runoff samples were lower than the baseflow mean for all sites. Nitrate loading was calculated for sample dates for which discharge was determined (Table 11). Unlike nitrate concentration, nitrate loading was generally greater in storm runoff samples than the baseflow mean due to increased discharge. 


\begin{tabular}{|l|r|r|r|r|r|r|r|r|}
\hline & $9 / 16 / 2010$ & $9 / 23 / 2010$ & $1 / 19 / 2011$ & $1 / 24 / 2011$ & $1 / 31 / 2011$ & 4/18/2011 & $\begin{array}{r}\text { Baseflow } \\
\text { Mean }\end{array}$ & 4/28/2011* \\
\hline $\begin{array}{l}\text { Apple } \\
\text { Spring }\end{array}$ & 0.7 & 0.8 & 1.0 & 1.0 & 0.9 & 0.4 & 0.8 & 0.6 \\
\hline $\begin{array}{l}\text { Raceway } \\
\text { West } \\
\text { Spring }\end{array}$ & 0.5 & 0.4 & 0.6 & 0.5 & 0.5 & 0.0 & 0.4 & 0.3 \\
\hline $\begin{array}{l}\text { Upper } \\
\text { Buckeye } \\
\text { Creek } \\
\text { Spring }\end{array}$ & 0.3 & 0.0 & 0.6 & 0.6 & 0.7 & 0.3 & 0.5 & 0.3 \\
\hline $\begin{array}{l}\text { Unnamed } \\
\text { Spring }\end{array}$ & 0.1 & 0.1 & 0.5 & 0.7 & 1.1 & 0.2 & 0.5 & 0.2 \\
\hline $\begin{array}{l}\text { Buckeye } \\
\text { Creek Cave } \\
\text { Entrance }\end{array}$ & - & - & 0.5 & 0.6 & 0.7 & 0.3 & 0.5 & 0.3 \\
\hline $\begin{array}{l}\text { Spencer } \\
\text { Resurgence }\end{array}$ & - & - & 0.9 & 1.3 & 1.1 & 0.4 & 0.9 & \\
\hline
\end{tabular}

$* 4 / 28 / 2011$ is a storm flow sample and is not included in the baseflow mean.

Table 10: Sample Nitrate $\left(\mathrm{NO}_{3}\right)$ in $\mathrm{mg} / \mathrm{L}$. Unlike FC concentrations, nitrate concentrations were higher during baseflow than in storm runoff samples.

\begin{tabular}{|l|r|r|r|r|r|r|}
\hline & $1 / 19 / 2011$ & $1 / 24 / 2011$ & $1 / 31 / 2011$ & $4 / 18 / 2011$ & $\begin{array}{r}\text { Baseflow } \\
\text { Mean }\end{array}$ & 4/28/2011* \\
\hline $\begin{array}{l}\text { Apple } \\
\text { Spring }\end{array}$ & 17.0 & 19.0 & 75.0 & 39.0 & 37.0 & 160.0 \\
\hline $\begin{array}{l}\text { Raceway } \\
\text { West } \\
\text { Spring }\end{array}$ & 0.0 & 0.2 & 0.1 & 0.0 & 0.0 & 0.7 \\
\hline $\begin{array}{l}\text { Upper } \\
\text { Buckeye } \\
\text { Creek } \\
\text { Spring }\end{array}$ & 3.2 & 3.4 & 120.0 & 150.0 & 69.0 & 350.0 \\
\hline $\begin{array}{l}\text { Unnamed } \\
\text { Spring }\end{array}$ & 0.1 & 0.2 & 31.0 & 1.8 & 8.2 & 5.8 \\
\hline $\begin{array}{l}\text { Buckeye } \\
\text { Creek Cave } \\
\text { Entrance }\end{array}$ & 4.2 & 4.5 & 100.0 & 200.0 & 78.0 & 270.0 \\
\hline $\begin{array}{l}\text { Spencer } \\
\text { Resurgence }\end{array}$ & 37.0 & 37.0 & 110.0 & 250.0 & 35.0 & 270.0 \\
\hline
\end{tabular}

$* 4 / 28 / 2011$ is a storm flow sample and is not included in the baseflow mean.

Table 11: Sample nitrate loading in $\mathrm{mg} \mathrm{NO}_{3} / \mathrm{s}$. Nitrate loading was generally greater for storm runoff samples than for baseflow despite the lower concentrations. 
Calcium and magnesium concentrations both generally were less in spring, compared to the fall and winter due to dilution by increased snow melt, precipitation, and surface runoff entering the system (Table 12 and Table 13). Calcium and magnesium concentrations are related and tend to be higher in the presence of "old" water that has been in the karst system for a long period. Calcium and magnesium loading both tend to be lower when "new" water from surface and atmospheric sources is present.

\begin{tabular}{|c|c|c|c|c|c|c|c|c|}
\hline & $9 / 16 / 2010$ & $9 / 23 / 2010$ & $1 / 19 / 2011$ & $1 / 24 / 2011$ & $1 / 31 / 2011$ & 4/18/2011 & $\begin{array}{r}\text { Baseflow } \\
\text { Mean }\end{array}$ & $4 / 28 / 2011 *$ \\
\hline $\begin{array}{l}\text { Apple } \\
\text { Spring }\end{array}$ & 28.3 & 33.2 & 25.3 & 21.6 & 16.7 & 16.8 & 23.7 & 19.0 \\
\hline $\begin{array}{l}\text { Raceway } \\
\text { West } \\
\text { Spring } \\
\end{array}$ & 53.2 & 50.2 & 56.9 & 56.2 & 42.4 & 17.4 & 46.1 & 13.8 \\
\hline $\begin{array}{l}\text { Upper } \\
\text { Buckeye } \\
\text { Creek } \\
\text { Spring }\end{array}$ & 44.1 & 50.4 & 48.0 & 49.7 & 45.9 & 33.5 & 45.3 & 31.2 \\
\hline $\begin{array}{l}\text { Unnamed } \\
\text { Spring }\end{array}$ & 50.7 & 67.5 & 66.2 & 70.6 & 74.6 & 82.2 & 68.7 & 63.2 \\
\hline $\begin{array}{l}\text { Buckeye } \\
\text { Creek Cave } \\
\text { Entrance }\end{array}$ & - & - & 44.4 & 49.5 & 56.1 & 32.9 & 45.7 & 37.1 \\
\hline $\begin{array}{l}\text { Spencer } \\
\text { Resurgence }\end{array}$ & - & - & 39.5 & 47.6 & 54.6 & 7.4 & 37.3 & 33.5 \\
\hline
\end{tabular}

$* 4 / 28 / 2011$ is a storm flow sample and is not included in the baseflow mean.

Table 12: Sample calcium concentration in $\mathrm{mg} / \mathrm{L}$. 


\begin{tabular}{|c|c|c|c|c|c|c|c|c|}
\hline & $9 / 16 / 2010$ & $9 / 23 / 2010$ & $1 / 19 / 2011$ & $1 / 24 / 2011$ & $1 / 31 / 2011$ & $4 / 18 / 2011$ & $\begin{array}{r}\text { Baseflow } \\
\text { Mean }\end{array}$ & $4 / 28 / 2011 *$ \\
\hline $\begin{array}{l}\text { Apple } \\
\text { Spring }\end{array}$ & 6.2 & 6.0 & 3.3 & 3.0 & 2.5 & 2.2 & 3.8 & 1.8 \\
\hline $\begin{array}{l}\text { Raceway } \\
\text { West } \\
\text { Spring }\end{array}$ & 7.6 & 6.8 & 3.7 & 3.6 & 2.1 & 2.2 & 4.3 & 1.5 \\
\hline $\begin{array}{l}\text { Upper } \\
\text { Buckeye } \\
\text { Creek } \\
\text { Spring }\end{array}$ & 6.0 & 6.8 & 3.6 & 3.8 & 3.3 & 2.4 & 4.3 & 2.0 \\
\hline $\begin{array}{l}\text { Unnamed } \\
\text { Spring }\end{array}$ & 11.0 & 8.7 & 4.6 & 4.3 & 3.9 & 5.3 & 6.3 & 2.5 \\
\hline $\begin{array}{l}\text { Buckeye } \\
\text { Creek Cave } \\
\text { Entrance }\end{array}$ & - & - & 3.3 & 3.7 & 4.3 & 2.3 & 3.4 & 2.6 \\
\hline $\begin{array}{l}\text { Spencer } \\
\text { Resurgence }\end{array}$ & - & - & 3.7 & 4.6 & 4.7 & 1.1 & 3.5 & 2.7 \\
\hline
\end{tabular}

*4/28/2011 is a storm flow sample and is not included in the baseflow mean.

Table 13: Sample magnesium concentration in $\mathrm{mg} / \mathrm{L}$.

No clear trends were observed in the $\mathrm{Ca}^{2+} / \mathrm{Mg}^{2+}$ ratios (Table 14). Storm runoff sample $\mathrm{Ca}^{2+} / \mathrm{Mg}^{2+}$ ratios were higher than the baseflow mean for all sites except for Raceway West.

\begin{tabular}{|c|c|c|c|c|c|c|c|c|}
\hline & $9 / 16 / 2010$ & $9 / 23 / 2010$ & $1 / 19 / 2011$ & $1 / 24 / 2011$ & $1 / 31 / 2011$ & $4 / 18 / 2011$ & $\begin{array}{r}\text { Baseflow } \\
\text { Mean }\end{array}$ & $4 / 28 / 2011 *$ \\
\hline $\begin{array}{l}\text { Apple } \\
\text { Spring }\end{array}$ & 2.8 & 3.4 & 4.7 & 4.4 & 4.1 & 4.7 & 4.0 & 6.4 \\
\hline $\begin{array}{l}\text { Raceway } \\
\text { West } \\
\text { Spring }\end{array}$ & 4.2 & 4.5 & 9.2 & 9.6 & 12.0 & 4.8 & 7.4 & 5.5 \\
\hline $\begin{array}{l}\text { Upper } \\
\text { Buckeye } \\
\text { Creek } \\
\text { Spring } \\
\end{array}$ & 4.5 & 4.5 & 8.0 & 7.9 & 8.3 & 8.6 & 7.0 & 9.5 \\
\hline $\begin{array}{l}\text { Unnamed } \\
\text { Spring }\end{array}$ & 2.8 & 4.7 & 8.7 & 10.0 & 12.0 & 9.3 & 7.9 & 15.0 \\
\hline $\begin{array}{l}\text { Buckeye } \\
\text { Creek Cave } \\
\text { Entrance }\end{array}$ & - & - & 8.2 & 8.1 & 7.9 & 8.8 & 8.3 & 8.6 \\
\hline $\begin{array}{l}\text { Spencer } \\
\text { Resurgence }\end{array}$ & & - & 6.4 & 6.6 & 7.0 & 4.1 & 6.1 & 7.6 \\
\hline
\end{tabular}

$* 4 / 28 / 2011$ is a storm flow sample and is not included in the baseflow mean.

Table 14: Calcium/magnesium molar ratios for collected samples. 
Quality control data showed some variability in calculated CFU (Appendix G). Most of the high percent differences between duplicate samples resulted from having small FC densities in the sample. Generally, the calculated CFU values were within an order of magnitude for each duplicate in the 1, 10, and $100 \mathrm{ml}$ tests for each sample. Accuracy of the FC numeration method was not tested using known concentrations.

The ion analysis calibration data generally shows good accuracy for calcium and magnesium concentration measurements. Calcium was measured within $0.1114 \mathrm{mg} / \mathrm{L}$ of the standard for the standard with the concentration closest to the samples, indicating an accuracy of $\pm 0.1 \mathrm{mg} / \mathrm{L}$. Magnesium measurements were slightly less accurate, with the test value within $1.0485 \mathrm{mg} / \mathrm{L}$ of the standard concentration for the standard with a concentration close to the collected samples, or approximately $\pm 1.0 \mathrm{mg} / \mathrm{L}$. Duplicate ion data showed some variability. The largest concentration difference measured for duplicate samples was $11.3939 \mathrm{mg} / \mathrm{L}$ for calcium concentration, although most differences were much smaller than this. Duplicate measurements of nitrate concentrations were all within $0.0287 \mathrm{mg} / \mathrm{L}$ of the sample value. Duplicate measurements of magnesium were all within $0.3472 \mathrm{mg} / \mathrm{L}$ of the sample value.

\section{Maps and GIS Data}

Spring and insurgence locations most commonly occur in the Union and Alderson formations, which are limestone-dominated parts of the Greenbrier Group (Figure 7). No springs or insurgences are located in non-karst shale-dominated Bluefield Formation in the Mauch Chunk Group. Connections between karst features in the basin have been demonstrated by dye tracing in previous studies (Jones, 1997; Dasher and Balfour, 1994; Dasher and Boyer, 2000). A complete list of dye tracings performed in Buckeye Creek basin is included in

\section{Appendix E.}




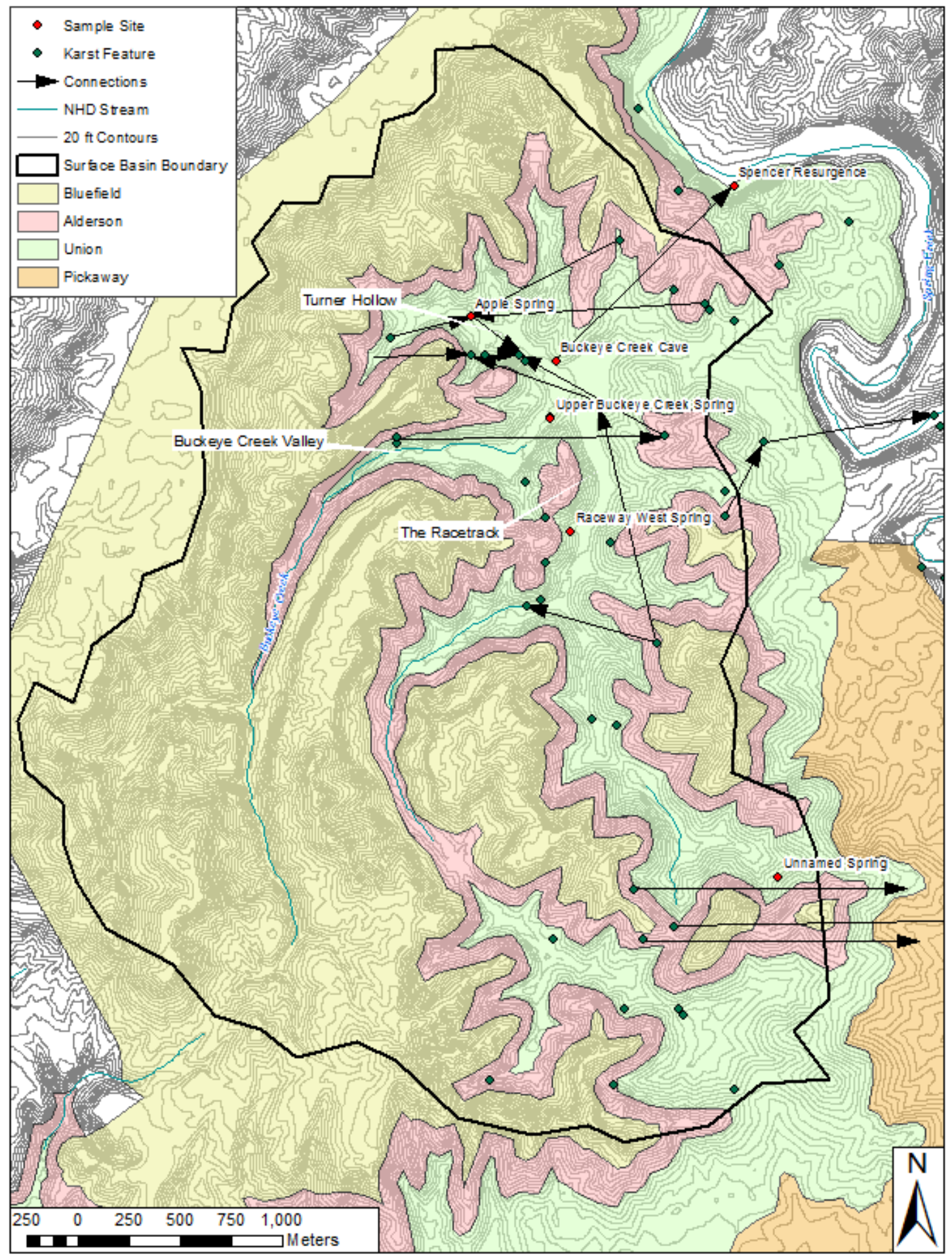

Figure 7: Buckeye Creek surface basin boundary with known subsurface connections and other karst features. Known connections between features and the flow directions of each are shown 
with arrows. (Contours from National Elevation Dataset DEM. Surface streams from NHD dataset; Karst feature data from field visits, 2010; Dasher and Balfour, 1994; Dasher and Boyer, 2000. Geologic polygons from Tudek, unpublished).

The most significant land uses in the basin are deciduous forest (83\%) and pasture (14\%), followed by open space (2\%) (Figure 8). Minor land uses in the basin include cropland and coniferous or mixed forest, which together make up about $1 \%$ of the basin. Land use varies somewhat in karst areas of the basin, with a lower portion of deciduous forest (79\%) and a higher portion of pasture (17\%), compared to the overall basin. 


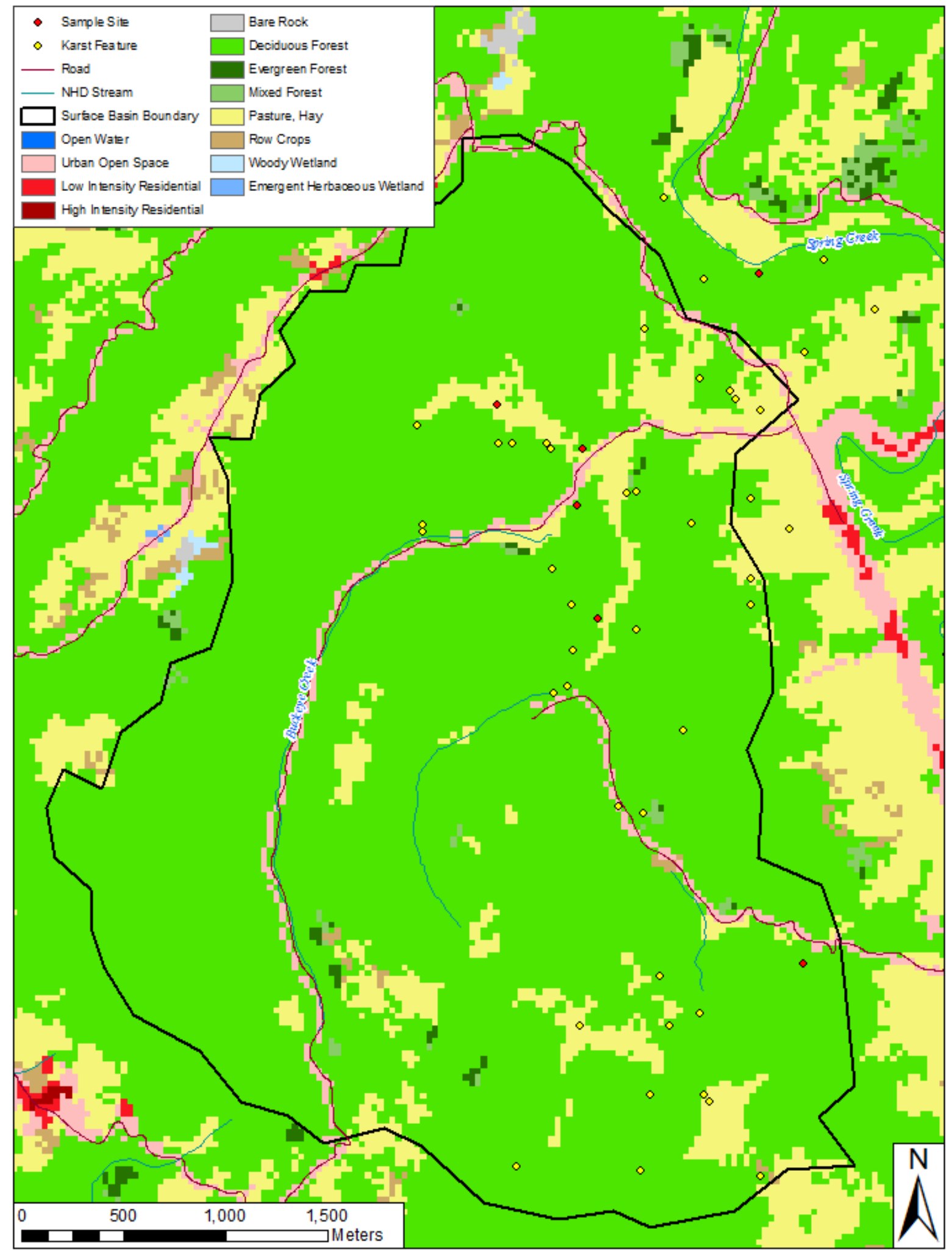

Figure 8: Buckeye Creek basin land use. Note the proximity of many mapped karst features to pasture land. 
After land uses in the basin were identified, the land use data set was reclassified as either agricultural land (crops or pasture) or all else. The land use data were then combined with the geologic data to determine where agricultural land overlies karst bedrock (Figure 9). All of the Greenbrier Group was considered potential karst bedrock, while all of the Mauch Chunk Group landscape was considered as non-karst. Karst agricultural land is vulnerable to agricultural groundwater contamination, and comprises $7 \%$ of the Buckeye Creek basin where agricultural BMPs should be considered. 


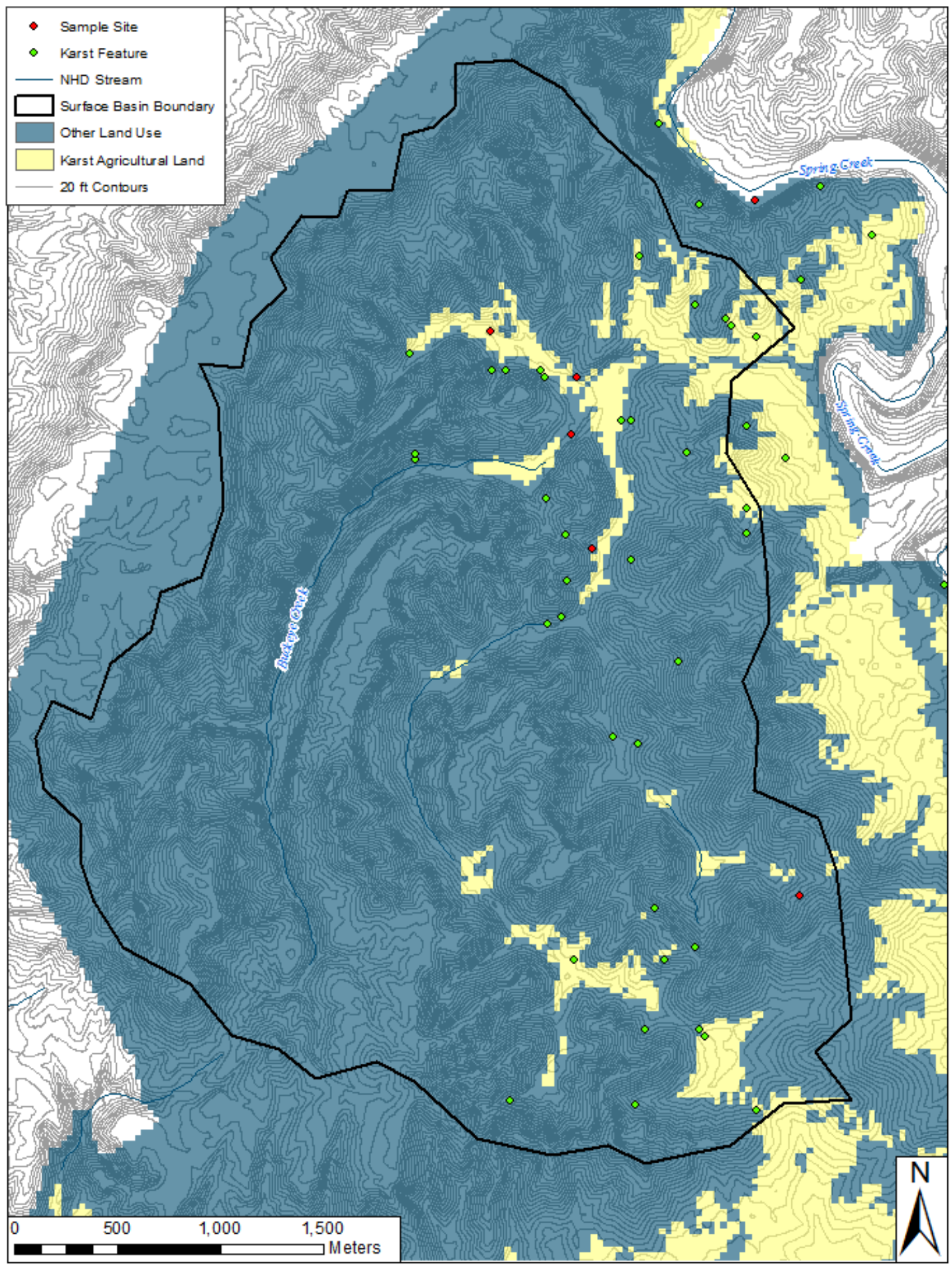

Figure 9: Buckeye Creek basin karst agricultural land use map. Agricultural land use on karst bedrock is shown in yellow. Agricultural land use areas that do not overlie karst bedrock are shown as "Other Land Use". 
After the land use and karst features maps were created, two approaches were used to identify potential contamination source areas in the basin. The first approach was to estimate the area contributing surface runoff to each sample site by manually digitizing subwatersheds (Figure 10). The five subwatersheds represent the area that could contribute contaminants to each sample site via surface runoff during storm flow. The area extending west and south of the Upper Buckeye Creek Spring is potential contributing area for the spring, and subsequently Buckeye Creek Cave. This area includes the Buckeye Creek surface valley and the areas surrounding Osbourne Insurgence and Lower Harrison Spring. Other areas contributing surface runoff to Buckeye Creek Cave Entrance include the Racetrack, Raceway East and West Springs, Cluetown Pit, and Fuells Fruit Cave. A subwatershed was not identified for Spencer Resurgence because it is the cave-fed outlet for the entire Buckeye Creek basin. In addition, most of the discharge from Spencer Resurgence comes directly from Buckeye Creek Cave, including subsurface inlets that flow into the cave, so a surface runoff watershed for Spencer Resurgence would not be representative of the contributing area. 


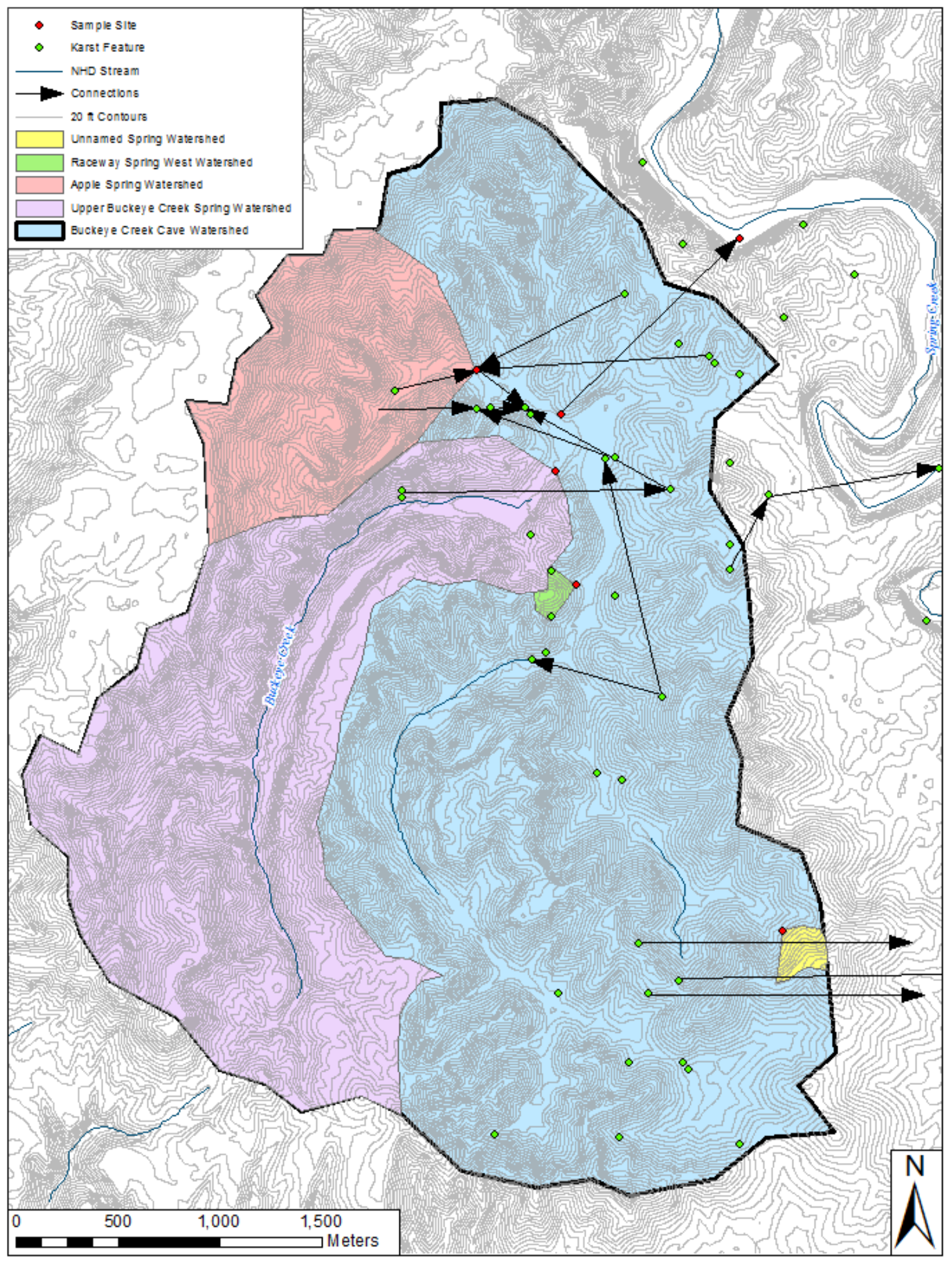

Figure 10: Surface runoff subwatersheds for each sample site. Spencer Resurgence watershed is not shown as it receives water from the entire Buckeye Creek basin. 
The next approach used to identify potential contamination source areas involved estimating the groundwater surface using Kriging in order to predict where subsurface contributions to each sample site might originate (Figure 11). The interpolated surface does not extend into the western portion of the basin because there are no spring elevations that can be used in calculations in the clastic Mauch Chunk bedrock. The surface could be extended by using wells to obtain additional groundwater elevation points, but for the purpose of this study, the subsurface model was not extended to the Mauch Chunk because the drainage on the Mauch Chunk is considered non-karst and is represented by the surface runoff model.

The groundwater surface elevation map produced by Kriging was found to be an improbable model in this karst system. The model had several limitations that prevented it from fully representing the way groundwater is likely to flow in this system. While some areas of the map appear to represent the expected subsurface flow direction, many areas of the map are contrary to the known connections. The model did predict a relative low point near the entrance to Buckeye Creek Cave. However, the interpolated surface does not reflect the known connection between this area and Spring Creek through the Buckeye Creek Cave because the model does not account for the low point in the potentiometric surface caused by the cave system. When compared to known subsurface connections, the model also performed poorly in predicting the groundwater flow direction in the southeast portion of the basin where it is partially perched on Culverson Creek basin. For these reasons, the known dye-traced subsurface connections are considered more accurate than the groundwater elevation model. 


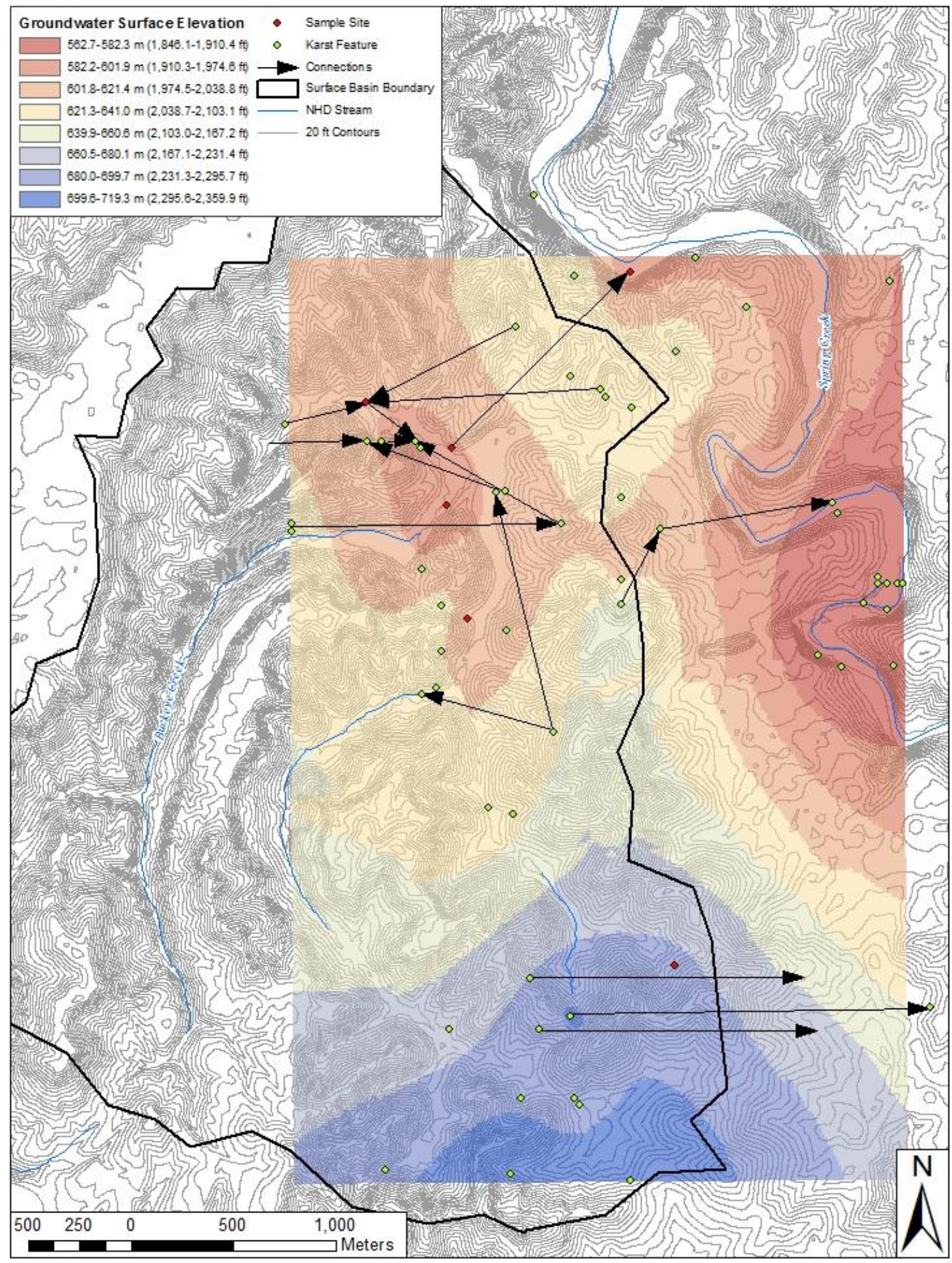

Figure 11: Estimated groundwater surface elevation interpolated by Kriging using spring elevations. 


\section{Data Analysis \\ Water Quality Analysis}

Statistical analysis was completed separately for three water quality data sets: a basinwide data set including all samples, a baseflow data set including only baseflow samples, and a log-transformed data set that included all samples. The data were not assumed to be normal; however the data were log-transformed to see if any significant statistical results would be obtained by assuming the data were log normal. Nonparametric tests were used to avoid the assumption that the data were normal.

The Wilcoxon rank sum test was used to test for between-site differences in discharge, FC concentration, FC loading, and $\mathrm{NO}_{3}$ concentration. The Wilcoxon method does not require an assumption of normality (Kvam and Vidakovic, 2007). Significant differences in discharge existed between several of the sites. Discharge differences are an important factor in overall contribution to contamination in the watershed, and therefore are also important in prioritizing the sites for water quality improvement efforts. For the basin-wide data set, Spencer Resurgence, Upper Buckeye Creek Spring, Apple Spring, and Buckeye Creek Cave Entrance all had significantly greater discharge than Raceway West Spring $(\mathrm{p}<0.05)$. Spencer Resurgence discharge was also significantly different from the unnamed spring $(\mathrm{p}<0.05)$. Spencer Resurgence, Upper Buckeye Creek Spring, Buckeye Creek Cave Entrance, and Apple Spring all had greater discharge relative to Raceway West and the unnamed spring for all sample dates, including during the dry season when flow from the latter two sites was almost nonexistent. Interestingly, the same statistical differences existed in the baseflow only data set. More storm runoff samples would be necessary to determine if storm flow significantly influences or changes the relative discharge relationships in this area. 
Differences in FC concentrations between the sites were not nearly as significant. For the baseflow only data set, Spencer Resurgence and Buckeye Creek Cave Entrance were significantly different $(\mathrm{p}<0.05)$. Upper Buckeye Creek Spring, which had the largest baseflow mean, had very weak significant difference from Apple Spring and Spencer Resurgence $(\mathrm{p}<0.1)$. When the storm runoff samples were included in the data set, no significant differences were found at all. Relationships between FC concentrations for the log transformed data set were also insignificant. A larger sample set may show significant differences in FC concentrations between sites, but using only the data available for this study, the FC concentration comparisons did not demonstrate very robust statistical results.

Despite the lack of significance in the FC concentration data, the considerable differences in discharge caused FC loading values to have a very wide range, with some being several orders of magnitude greater than other sites on the same date. For baseflow data, Spencer Resurgence, Upper Buckeye Creek, Buckeye Creek Cave Entrance, and Apple Spring all had significantly greater FC loading than Raceway West Spring $(\mathrm{p}<0.05)$. Basin-wide data revealed all of these sites except Apple Spring remained significantly greater than Raceway West. The same relationships existed for log transformed data.

Distributions were examined graphically for fecal coliform density (Figure 12) and fecal coliform loading (Figure 13) for each sample site. While not necessarily statistically supported, the distributions illustrate potentially important considerations in interpreting the data, including the range of variability in samples within each site and the degree of difference between the baseflow samples and storm runoff samples. 


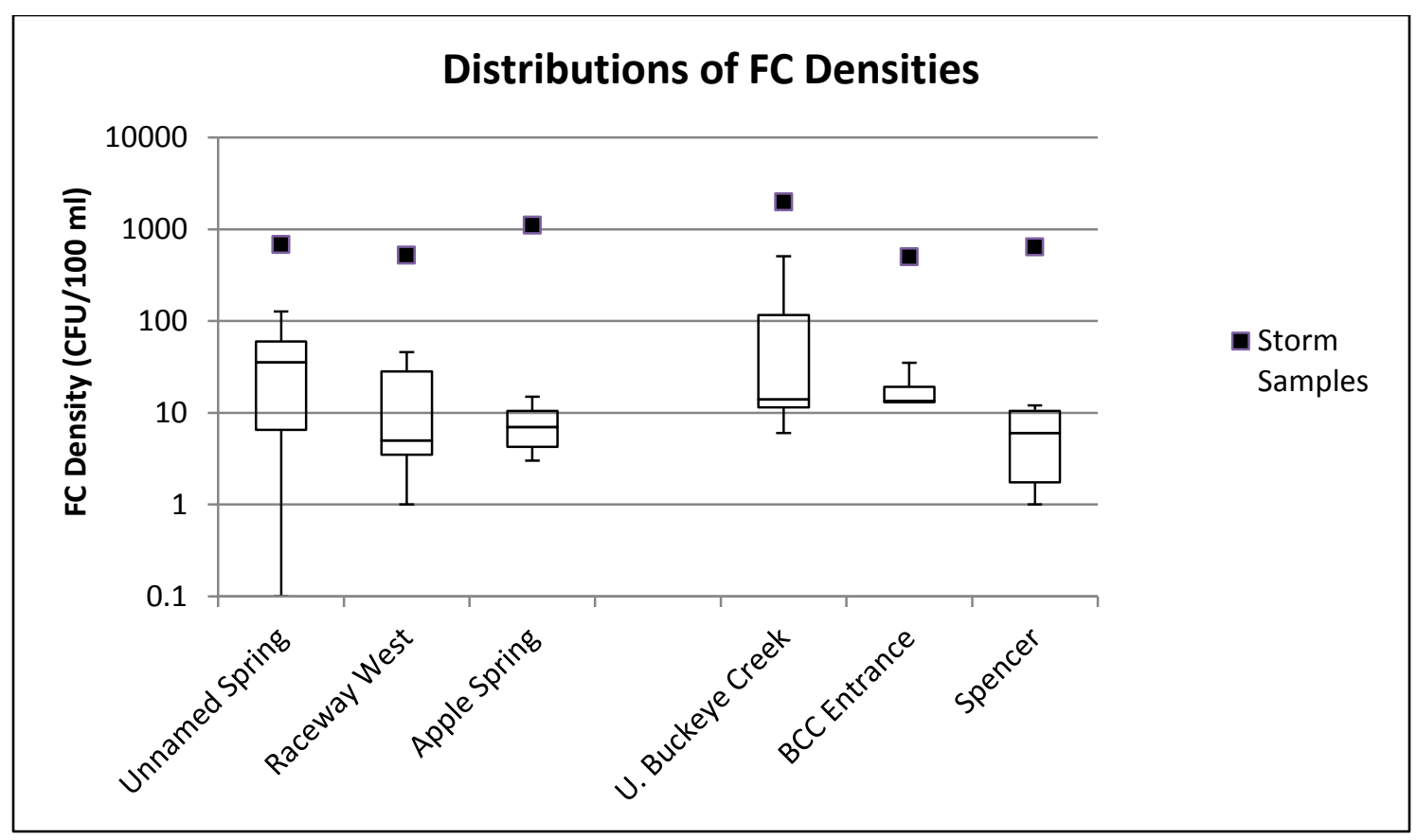

Figure 12: Distributions of fecal coliform densities by site. Baseflow values are represented by the box-and-whiskers distribution, and storm runoff samples are shown as outliers. Note that the data are represented on a log scale. 


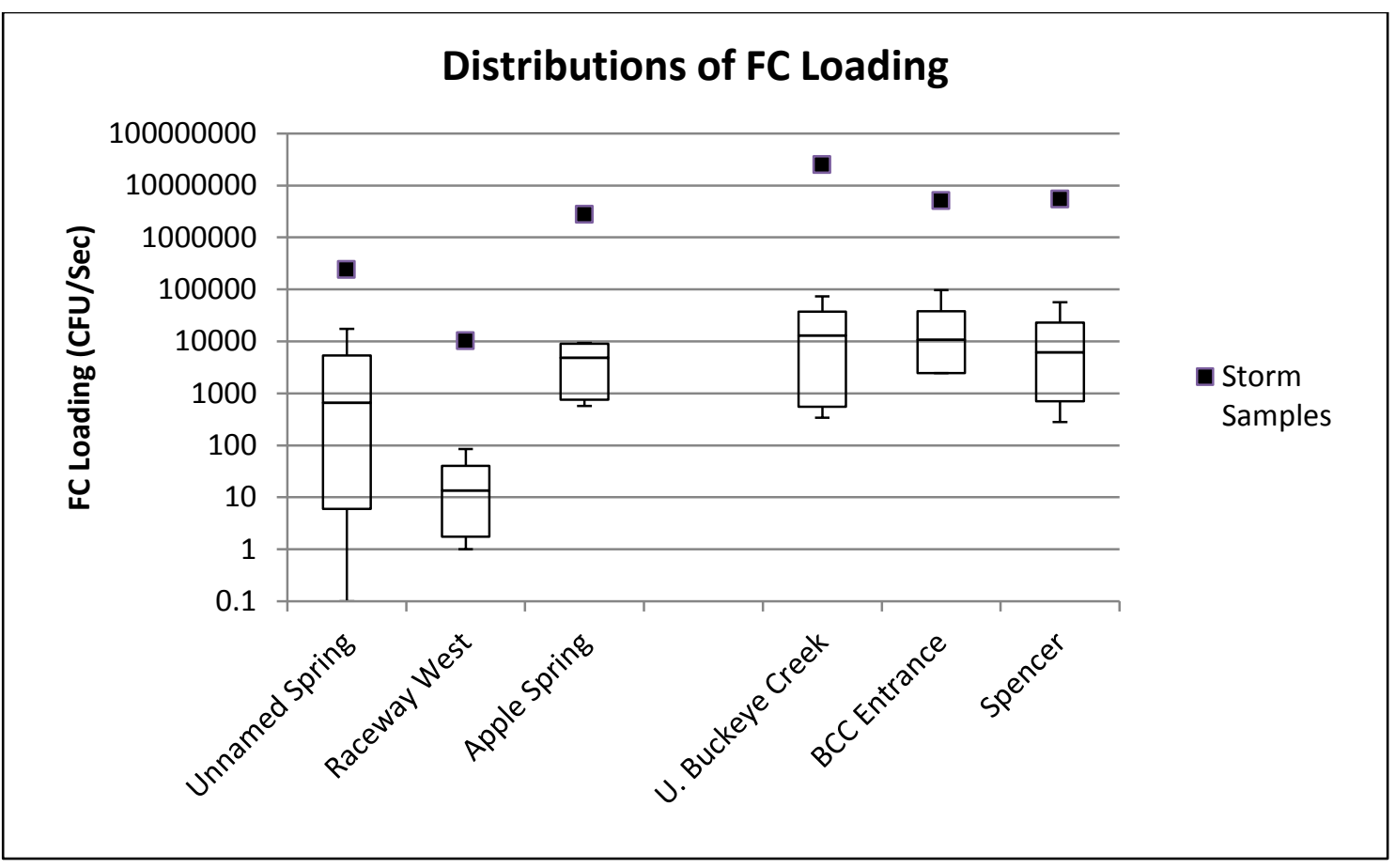

Figure 13: Distributions of fecal coliform loading by site. Baseflow values are represented by the box-and-whiskers distribution, and storm runoff samples are shown as outliers. Note that the data are represented on a log scale.

Nitrate concentrations were also analyzed as an indicator of agricultural contaminants. Nitrate concentration differences were more statistically significant than FC concentrations. For the basin-wide data, Apple Spring had significantly higher nitrate concentrations than Upper Buckeye Creek and Raceway West ( $\mathrm{p}$ <0.05). In addition, Apple Spring was weakly significantly different from Buckeye Creek Cave Entrance, and the unnamed spring $(\mathrm{p}<0.1)$. For the baseflow data set, Apple Spring had significantly greater nitrate concentrations than both Upper Buckeye Creek and Raceway West $(\mathrm{p}<0.05)$ and weak differences from Buckeye Creek Cave Entrance ( $\mathrm{p}<0.1)$. 
Spearman's rank correlation coefficient (Spearman's $p$ ) is a nonparametric equivalent to standard Pearson's correlation coefficient, and does not assume normality (Kvam and Vidakovic, 2007). Correlations were calculated using Spearman's $p$ to examine the relationships between pairs of variables (Tables 15 and 16). Significant correlations in both basin-wide and baseflow data sets included FC density and water temperature (positive), discharge and water temperature (positive), alkalinity and water temperature (negative), nitrate and FC density (negative), calcium and water temperature (negative), calcium and discharge (negative), magnesium and calcium (positive). Some of the correlations are not meaningful because of the inherent relationships between the variables (such as the positive correlation between FC loading and discharge). The negative correlation found between FC concentrations and nitrate was contrary to what might be expected. Other relationships, such as the positive correlations between alkalinity, calcium, and magnesium were found as expected. 


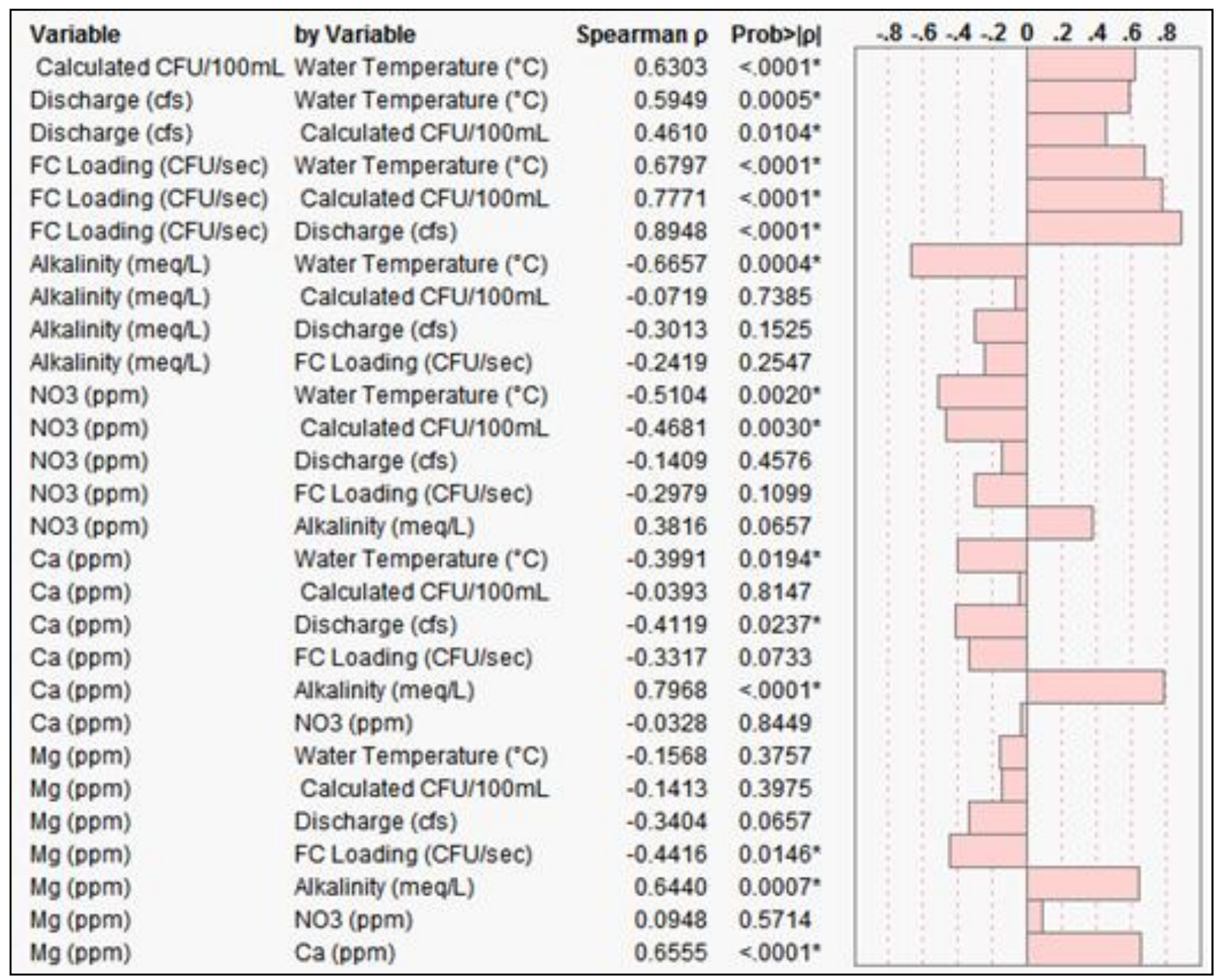

Table 15: Spearman's rank correlation coefficients (p) for basin-wide data. Correlations at the 95\% confidence limit were considered significant, as noted by asterisks. 


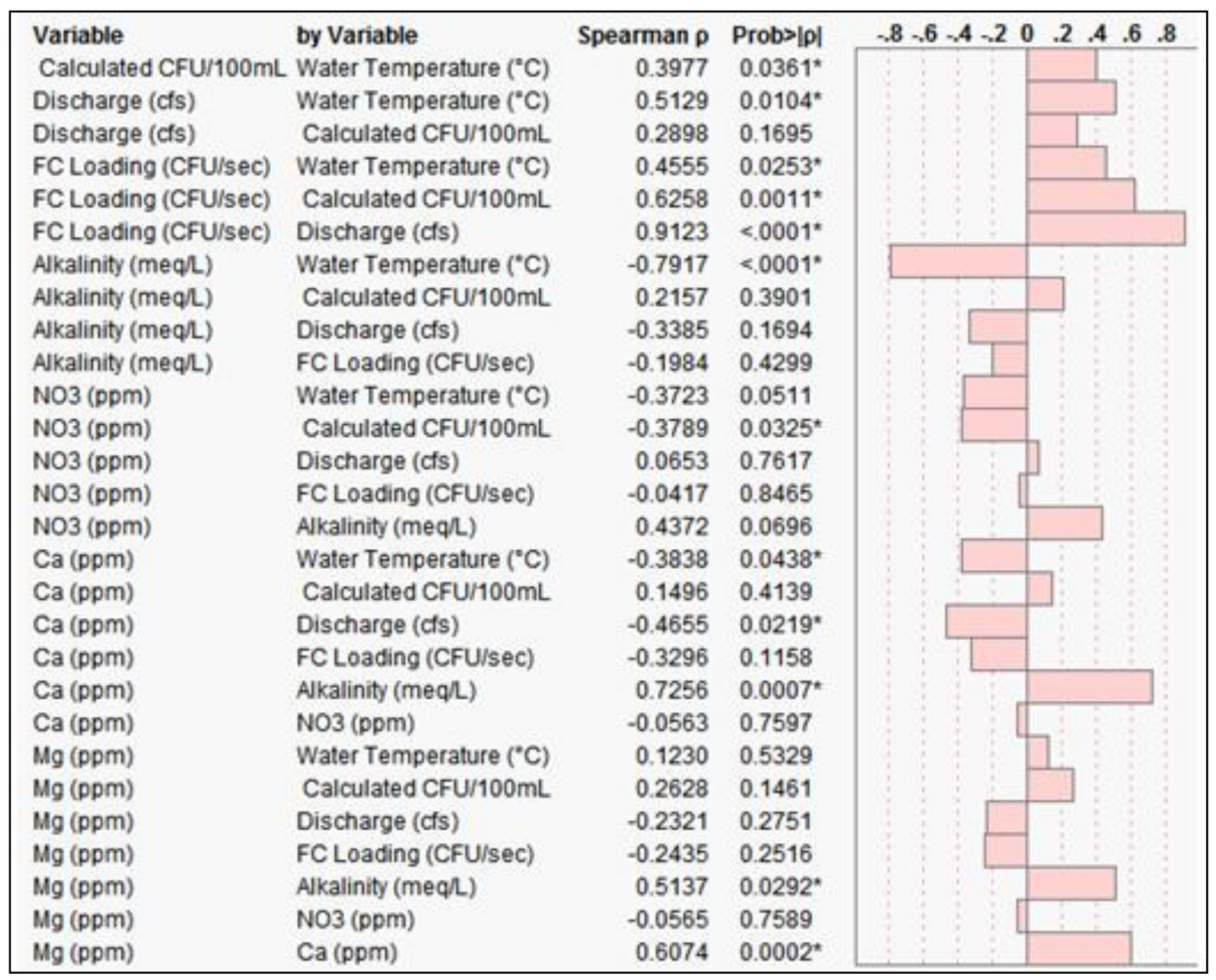

Table 16: Spearman's rank correlation coefficients $(p)$ for baseflow data. Correlations at the 95\% confidence limit were considered significant, as noted by asterisks.

\section{Relative Priority Scores}

Relative priority scores were calculated for the sample sites (Table 17) using the decision-making process described in the methods section applied to baseflow mean data. The relative priority score provides an alternative to statistical ranking because the statistical analysis is not robust due to the small sample set available for this research. Relative priority scores instead provide a way to rank the need for water quality improvements using only the available data, which may be useful in other watersheds where only limited data or analytic resources are 
available. The relative priority scores also provide a starting point from which immediate water quality improvement efforts can be directed at more critical contamination sources while additional data are gathered.

\begin{tabular}{|l|l|r|r|r|r|r|r|}
\hline Source & Use & Concentration & Discharge & Total Loading & Use Factor & Contamination Factor & Score \\
\hline & & (CFU/100ml) & (L/s) & (CFU/second) & (unitless) & (unitless) & (Relative Units) \\
Apple Spring & Agricultural & 8 & 55.0 & 4,900 & 1 & 49,000 \\
Raceway West & Agricultural & 16 & 0.3 & 28 & 10 & 280 \\
U. Buckeye Creek & Agricultural & 119 & 190.0 & 25,000 & 10 & 1 \\
Unnamed Spring & Other & 43 & 9.3 & 4,700 & 1 & 1 \\
BCC Entrance & Recreation & 19 & 230.0 & 30,000 & 10 & 1 & 1 \\
Spencer & Recreation & 6 & 180.0 & 17,000 & 10 & 4,700 \\
\hline
\end{tabular}

(Data entered in all columns is baseflow mean)

Table 17: Relative priority scores for baseflow samples.

Relative priority scores were also calculated using the storm flow data by the same method (Table 18). Additional storm data would provide a more representative mean, but even the single storm date data provide insight into how contaminant loading during storm flow increases greatly compared to baseflow loading.

\begin{tabular}{|l|l|r|r|r|r|r|r|}
\hline Source & Use & Concentration & Discharge & Total Loading & Use Factor & Contamination Factor & Score \\
\hline & & (CFU/100ml) & (L/s) & (CFU/second) & (unitless) & (unitless) & (Relative Units) \\
Apple Spring & Agricultural & 1100 & 250.0 & $2,800,000$ & 10 & $28,000,000$ \\
Raceway West & Agricultural & 520 & 2.0 & 10,000 & 10 & 1 \\
U. Buckeye Creek & Agricultural & 1975 & 1300.0 & $25,000,000$ & 10 & 100,000 \\
Unnamed Spring & Other & 680 & 35.0 & 240,000 & 1 & $250,000,000$ \\
BCC Entrance & Recreation & 500 & 1000.0 & $5,100,000$ & 10 & 240,000 \\
Spencer & Recreation & 640 & 850.0 & $5,400,000$ & 10 & 1 \\
\hline
\end{tabular}

(Data entered in all columns is storm flow value)

Table 18: Relative priority scores for storm runoff samples.

Buckeye Creek Cave Entrance had the highest RPS for baseflow samples, which was only slightly higher than the RPS for Upper Buckeye Creek. For storm flow samples, Upper Buckeye Creek had the highest RPS, and FC loading was nearly three times the rates at Buckeye 
Creek Cave Entrance and Spencer Resurgence. Apple Spring had a low RPS compared to other sites for baseflow samples, but the RPS for the storm sample was slightly higher.

\section{Discussion}

\section{Precipitation and Temperature}

Following each of the precipitation events that were examined, the Greenbrier River discharge peaked approximately one day after the event, indicating that snowmelt likely did not have a significant effect on the timing of the temperature changes (Figure 6). The temperature peaks at both springs tended to generally correspond in timing. This may indicate similar groundwater and surface water inputs at these two sites, although more events should be analyzed to support this observation. Both springs are located in the Union Limestone; however the unnamed spring is significantly higher in elevation than Apple Spring. The differences observed in the temperature graphs for the two sites may be due in part to the $82 \mathrm{~m}(270 \mathrm{ft})$ elevation difference. Other factors may include difference in depth and elevation of the groundwater recharge areas for each spring and the varying geologic characteristics that occur in different parts of this relatively thick formation.

\section{Water Quality Data}

Previous studies have demonstrated that water quality in karst areas degrades significantly due to increased runoff immediately following precipitation (Ryan and Meiman, 1996). As expected, this study showed significantly greater fecal coliform density in the storm runoff samples compared to the baseflow samples. Nitrate concentration in storm runoff samples was actually less than the baseflow mean for all sites. This contrast is likely due to differences in 
FC and nitrate transport. While FC tends to associate with sediment and be washed into the groundwater during times of increased surface runoff, nitrate is water soluble and therefore has different transport mechanisms and time of travel (Mahler, et al., 2000). Multiple storm runoff samples as well as time interval samples for each storm event would be needed to test this explanation. Also as expected, discharge increased significantly following the storm event, when alkalinity, calcium concentration, and magnesium concentration were lower than the baseflow mean for all sites.

Due to the significant increases in both FC concentration and discharge, FC loading also increased dramatically during storm runoff. This increase in storm runoff sample FC loading values ranged from 50 times the baseflow mean (in the unnamed spring) to over 1000 times the baseflow mean (in Upper Buckeye Creek Spring). This single storm runoff sample set shows extreme variability in water quality, although these increases in FC loading may or may not be representative of typical loading contributions to the basin from each sample site. Interestingly, when the relationship between RPS and discharge is examined for the baseflow data, the score appears to be almost entirely controlled by discharge. However, this linear relationship does not exist between the RPS and discharge for the storm sample set. The lack of a clear trend between discharge and RPS in the storm samples may be due to the fact that only one sample date is included, but is also very likely related to the variability of water quality during the storm event. This suggests that all locations do not respond to storms in the same way, and may not be equally vulnerable to groundwater contamination due to storm runoff.

Variations due to seasonality and temperature were also observed. Statistically, water temperature at the time of sampling was positively correlated with FC concentration, discharge, and FC loading, but negatively correlated with alkalinity and calcium. The correlation between 
discharge and temperature occurred simply because spring runoff caused much greater discharge than in the winter months. This correlation almost certainly would be less significant or nonexistent if sampling continued into the summer months of 2011 when water levels decreased in the basin. The correlation between temperature and calcium is also skewed by sampling in only three seasons, and is not likely a real correlation. The correlation between temperature and calcium concentration is expected to change seasonally rather than remain constant throughout the year.

The positive correlation between water temperature and FC loading is related to both the correlation with discharge and the correlation of temperature with FC concentration, which may be caused by several factors. In a neighboring basin, Boyer and Kuczynska, (2003) found that FC densities in storm flow were highest in the summer, followed by spring, then fall, then winter, so this correlation was expected. Higher FC densities during the warmest months may be caused by decreased water flow dilution, by a true increase in FC populations, or both. The positive correlation between water temperature and discharge in this study indicates that increased FC concentrations were not caused by decreased dilution. Rather concentrations increased due to increases in FC populations due to factors such as decreased die-off of FC, flushing of FC stored in the epikarst and on the surface during spring runoff, and the increase in cattle in pastures due to calving in the spring.

These correlations in this study were found for data from all locations together in order to increase the sample size to reveal more significant correlations. However, the correlations between the measured parameters may not be the same at all locations. Another interesting analysis might be to test these correlations by calculating for each location separately. 
Additional samples at each location would likely be needed in order to reveal significant differences in correlations between locations.

Besides seasonal and storm flow differences, the sample sites were also compared to each other for each sample date and for the entire duration of the study. The highest FC concentrations and FC loading values were observed at Upper Buckeye Creek Spring and Buckeye Creek Cave Entrance more often than any of the other sites (Table 19). The high FC loading values at these two sites are explained by the high measured discharges. The high FC concentrations may be due to the influence of Buckeye Creek surface flow and subsurface drainage to both of these sites.

\begin{tabular}{|l|l|l|}
\hline \multicolumn{1}{|c|}{ Date } & \multicolumn{1}{|c|}{$\begin{array}{c}\text { Highest Observed FC Concentration } \\
\text { (concentration in CFU/100 ml) }\end{array}$} & \multicolumn{1}{|c|}{$\begin{array}{c}\text { Highest Observed FC Loading } \\
\text { (loading in CFU/s) }\end{array}$} \\
\hline $9 / 16 / 2010$ & Upper Buckeye Creek Spring (160) & Not determined \\
\hline $9 / 23 / 2010$ & Upper Buckeye Creek Spring (510) & Not determined \\
\hline $1 / 19 / 2011$ & Buckeye Creek Cave Entrance (35) & Buckeye Creek Cave Entrance $(2,973)$ \\
\hline $1 / 24 / 2011$ & Buckeye Creek Cave Entrance (14) & Buckeye Creek Cave Entrance $(991)$ \\
\hline $1 / 31 / 2011$ & Unnamed Spring (62) & Upper Buckeye Creek Spring $(25,488)$ \\
\hline $4 / 18 / 2011$ & Unnamed Spring (17) & Buckeye Creek Cave Entrance $(97,194)$ \\
\hline $4 / 28 / 2011$ & Upper Buckeye Creek Spring $(1,975)$ & Upper Buckeye Creek Spring $(25,169,400)$ \\
\hline
\end{tabular}

Table 19: Location of highest observed FC concentrations and FC loading values by date.

When all samples from each site were compared, no particular site stood out as significantly different from others in terms of FC concentration due to the large variability between samples taken on different dates and the small number of samples. Despite the weak results from statistical analysis of the FC concentrations, the distributions show that Upper Buckeye Creek, Buckeye Creek Cave Entrance, and Spencer Resurgence have higher storm runoff sample values, medians, and maximum baseflow values than the other three sites. 
The sites showed more notable differences in FC loading, with values influenced more by discharge than FC concentrations. FC loading values varied greatly because of the large changes in discharge. Raceway West was by far the smallest contributor of FC bacteria to the basin and was significantly different from all other sites except the unnamed spring for baseflow data due to its low discharge. When visually analyzing the distributions, Upper Buckeye Creek, Buckeye Creek Cave Entrance, and Spencer Resurgence all had comparable FC loading values that were higher than other sites, likely due to their hydrologic connectivity. Upper Buckeye Creek had both the highest storm runoff sample value and the highest median value, perhaps due to the influx of runoff from the surface channel of Buckeye Creek. Apple Spring was lower but relatively close to the top three, followed by the unnamed spring, which showed much more variability than Apple Spring over the study.

\section{Relative Priority of Sites}

Relative priority scores (RPS) clearly identified a group of higher priority sites: Upper Buckeye Creek Spring, Buckeye Creek Cave Entrance, and Spencer Resurgence. Not only do these sites have greater discharge than the other three sites, but they are also directly connected to one another so that the water quality of the upstream sites affects the downstream sites. Any water quality improvement efforts that target water draining to and from these major sites has potential to be more effective than those at the smaller sites. Contamination at Upper Buckeye Creek Spring is considered the first priority to address due to its position directly upstream of both Buckeye Creek Cave and Spencer Resurgence. It is likely that water quality improvements to Upper Buckeye Creek would improve water quality at Buckeye Creek Cave Entrance and Spencer Resurgence, and thus potentially achieve watershed-scale improvements. 
Buckeye Creek Cave Entrance and Spencer Resurgence are considered second priorities for water quality improvement effort after Upper Buckeye Creek Spring. Because Spencer Resurgence reflects the water quality of several groundwater inputs in addition to Buckeye Creek, it may be easier to address the water quality of water at the entrance than it would be at the resurgence. The similarity of the FC contamination level and the RPS scores at these two sites also shows that much of the contamination is entering the system before the Buckeye Creek Cave Entrance, meaning that it would be important to address water quality before it enters the cave. Improvement efforts at this level could improve watershed-scale water quality and decrease the amount of total loading to Spring Creek, which WVDEP considers to be impaired.

Raceway West, the unnamed spring, and Apple Spring had lower RPS than the other three sites for both baseflow and storm runoff samples. Groundwater quality improvement efforts at Raceway West, the unnamed spring, or Apple Spring are all considered less likely to produce effective results on a watershed scale. Raceway West Spring had significantly smaller FC loading than all other sites and also had a low mean FC concentration and the lowest RPS for both baseflow and storm samples. The unnamed spring had large variability in FC loading, but loading values were generally lower than other sites, because the site maintained low discharge throughout the study. Apple Spring had a higher RPS for the storm sample compared to baseflow samples, suggesting that during a rain event, the increase in FC loading at Apple Spring may be greater than the increase at other sites. If this is true, relative priority for conservation efforts may be higher, but given only the available samples, Apple Spring is a much less important contributor than the top three sites. 


\section{BMP Summary and Suggestions}

The main objective of BMPs listed in this study is to reduce the opportunity for agricultural runoff and animal waste to enter sinkholes and subsurface drainage, so data collected in this study were only applicable for developing BMPs that would reduce fecal coliform bacteria or nitrate contamination. However, BMPs that address these agricultural contaminants could also reduce other contaminants, including sediment, other nutrients, and other biological contaminants. This study does not include other BMPs such as urban practices, fertilizer application management, integrated pest management, or rotational cropping practices, which were left out because most water contamination in Buckeye Creek basin comes from either pasture runoff or animal wastes deposited near karst inlets.

Choosing the most suitable and most effective BMP for a specific site depends on the land use, the local drainage, the economic feasibility, and various other factors. Vegetated buffers or riparian vegetation are commonly used to inhibit runoff from reaching surface waters or karst groundwater inlet points. In some areas, such as pastures, other practices could include sinkhole filters at well-defined sinkholes, or cattle exclusion fences where a sinking stream or surface channel exists. Additionally, rotational grazing and water distribution systems may be options to disperse cattle away from these features, especially in peak seasons for fecal coliform bacteria and during forecasted rain events. In concentrated animal operations, such as feedlots and dairies, there may be a need for waste management plans or waste storage structures to prevent large amounts of nutrients and pathogens from rapidly entering the karst groundwater during runoff events.

Karst-specific research was carefully considered when choosing BMPs in this study. Much of the current research involving agricultural BMP effectiveness has been completed in 
non-karst areas, which presents a problem in selecting and suggesting BMPs for implementation in karst drainage basins. For example, a cattle exclusion fence along a stream in a non-karst area can effectively reduce animal waste and sediment entering the stream, but in a karst pasture, cattle exclusion may be less effective because of the surface water-groundwater connection and the lack of adequate filtration in the soil. However, studies have shown that certain BMPs are much more effective than others in karst drainage basins.

Currens (2002) found partial success, including reduced bacteria counts, with BMPs in a conduit-flow-dominated karst watershed in Kentucky, and concluded that BMP efforts in karst agricultural watersheds should emphasize vegetative buffer strips and livestock exclusion from streams and karst windows. Currens also suggested that removing vulnerable karst land from agricultural production could be an effective way to protect karst water quality. A modeling study completed by Petersen and Vondracek (2006) also emphasized the use of vegetative buffers around sinkholes and karst inlets, similar to riparian buffers in non-karst areas. Both Currens (2002) and Petersen and Vondracek (2006) concluded that a significant amount of reduction in sediment and sediment-bound contaminants could be achieved in karst areas with appropriately placed BMPs. Boyer (2008) evaluated sinkhole filters used either alternatively to or in conjunction with vegetative filter strips and found that sinkhole filters effectively remove sediment and associated contaminants, but not nitrate. However, because of the material cost and the need to modify the filter design for each individual sinkhole, sinkhole filters are likely to have a higher cost relative to vegetative buffers alone.

Several studies have shown that vegetative buffers are effective at reducing sediment and sediment-associated contaminants in karst waters, but the results for other contaminants have been less conclusive (Currens, 2002; Petersen and Vondracek, 2006). Although vegetative 
buffers in karst areas are less effective for reducing soluble contaminants like nitrate, some amount of reduction can be expected due to plant uptake (Petersen and Vondracek, 2006). Buffers may also reduce flashy discharge, potentially preventing contaminant peaks that may temporarily exceed water quality standards. Based previous studies and the low cost of vegetative buffer implementation and maintenance relative to other BMPs, buffers are a good option for many sites in the study area, especially where prominent sinkholes exist. In heavily grazed areas that include not only sinkholes but other karst features such as dry surface channels, cattle exclusion fences may be considered as another relatively low-cost option.

In the data analysis of this study, both FC concentration (in CFU/100 ml) and total FC loading (in CFU/s) were examined, but total loading was considered more important for determining priority for BMP placement because loading reduction can produce water quality improvement on the watershed scale. However, FC concentration is also important to water quality, especially in regulatory requirements and human health concerns. The goal of effective FC loading reduction on the watershed scale is to ultimately reduce the FC concentration in receiving waterbodies.

\section{Potential Contamination Sites}

After examination of the sample data, the statistical analysis, and the RPS values, it was determined that Upper Buckeye Creek Spring was the most critical contamination site in the basin, followed by Buckeye Creek Cave Entrance and Spencer Resurgence. The potential contamination source areas for these sites were examined using the models created in this study. Known connections were examined first. The surface runoff subwatersheds for each of the sites were examined next. The groundwater surface elevations estimated by kriging were not considered to be a representative model of the system, and were only used to see if the general 
flow directions predicted in the basin agreed with the known connections and surface watersheds shown in the other two models. As expected, the groundwater surface elevation map shows that the general trend of groundwater flow in the basin is from south and west towards the northeast (Figure 11). However, due to the limitations of the model, it is not likely to correctly indicate local flow directions, especially in the vicinity of the cave system or in the perched section of the basin.

In general, the groundwater surface elevation map indicates that the same areas contributing surface runoff to these sites may be contributing groundwater flow as well, so this model would not significantly change conclusions if it had been considered representative of the system. The groundwater surface map shows a low area surrounding the entrance to Buckeye Creek Cave that is corroborated by the known connections and the understanding that spring water in this region of the basin flows into Buckeye Creek Cave through the entrance (Figure 14). These connections indicate that groundwater moves primarily to the entrance of Buckeye Creek Cave from other areas in the basin, rather than exiting the basin directly into Spring Creek, despite the fact that water is moving in a direction opposite to the general topographic trend in the basin. These connections flow southwest from Short Stuff Cave to Apple Spring and west from Turner Pit \#2 to Apple Spring. Water also flows east from Cluetown Pit to Rock Spring and from Fuells Fruit Cave to Cliff Spring in this area of the basin. This routing means that areas to the northeast of Buckeye Creek Cave entrance could also be contributing contaminated water to at least Buckeye Creek Cave and Spencer Resurgence and possibly Upper Buckeye Creek Spring.

The potential contamination source areas provided by the flow models were then compared to the map of agricultural land use in karst areas. Since most of the contamination in 
the basin is assumed to come from agriculture, and contamination enters the groundwater more easily in karst areas, karst agricultural land that is also in the contributing areas for the high priority sites should be the focus of BMP implementation in this basin. Deer Insurgence, Cluetown Pit, Short Stuff Cave, and Turner Pit \#2 are major sinks in the basin that are potential contamination sources for the top priority sites based on land use, karst hydrology, and location. Hughes Spring and Hughes Cedar Spring also sink at an unnamed insurgence that is connected to Buckeye Creek Cave. All six of these sites are located within the northeast portion of the basin (Figure 13). Beaver Dam Insurgence and Fuells Fruit Cave are examples of important sinks in the basin that contribute water to the top priority sites, but because they are not in agricultural land, they are not considered likely contamination sources and are not potential sites for agricultural BMP implementation. Additional areas that may be directly contributing to the sample sites include the agricultural parts of Turner Hollow, the Racetrack, and Buckeye Creek Valley. These areas are narrow bands of pasture, but any surface sinks in these areas could be contributing considerable amounts of contaminated runoff to the groundwater in the basin. 


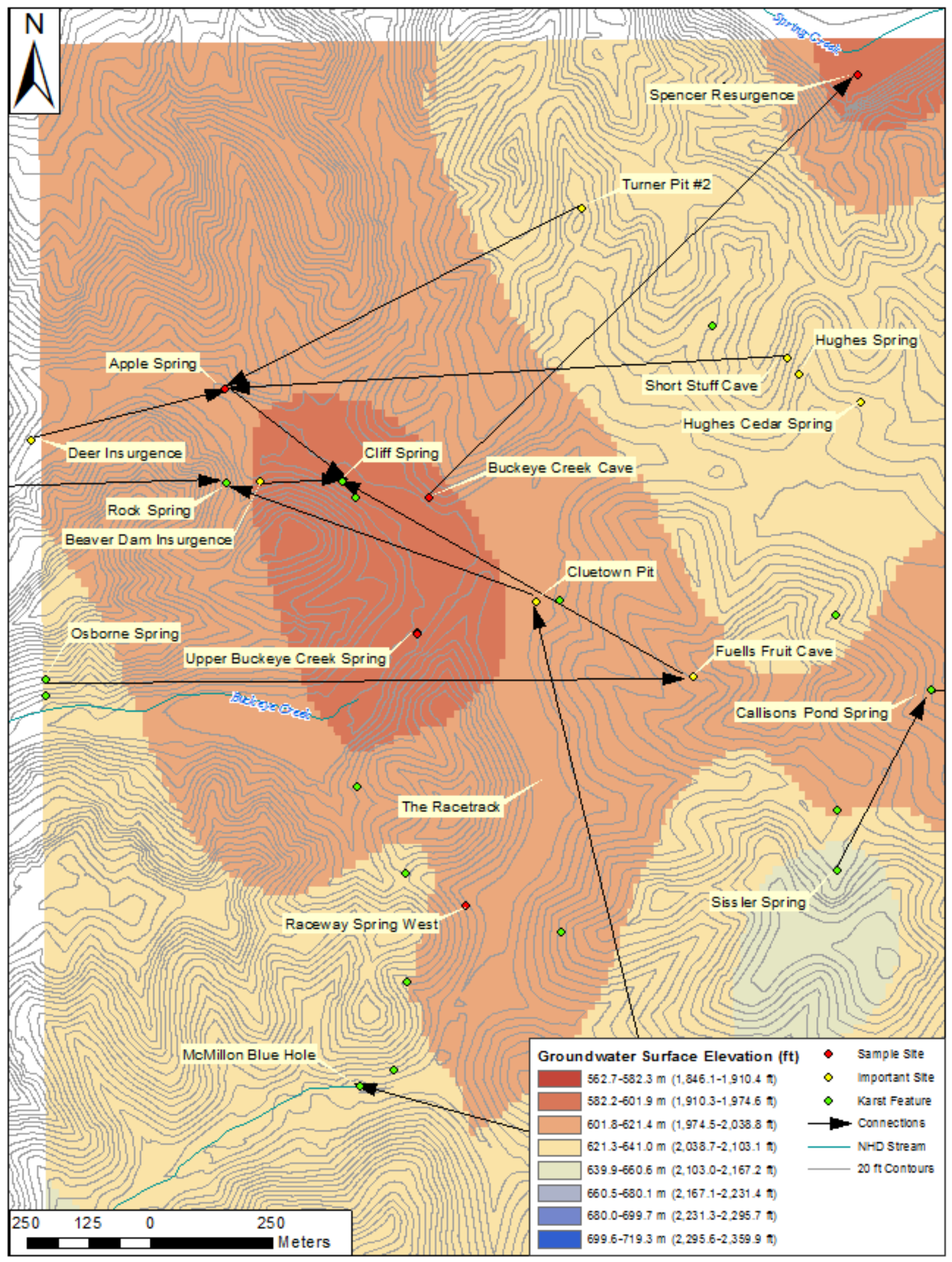

Figure 14: Locations of important sites for BMP consideration. 


\section{Conclusions}

Several informed recommendations for improving basin-wide water quality can be made based on the data collected in this study. The most important areas for water quality improvement are the pastures immediately surrounding the highest priority sampling sites, as shown in Figure 15. These include the area surrounding the Buckeye Creek Cave Entrance and the area surrounding Apple Spring, up the valley from the entrance, which both contain significant surface streams. The streams are not protected by riparian forests and receive a large amount of sediment and associated contaminants during surface runoff. These two stream reaches, shown in photos in Appendix F, would benefit greatly from a vegetated riparian buffer, preferably in conjunction with a fence excluding animals from the stream. While the area immediately upstream of Upper Buckeye Creek Spring is forested, the surface valley of Buckeye Creek runs through a section of pasture further upstream. This segment of Buckeye Creek would also be a good location for a vegetated riparian corridor. During precipitation events, much of the runoff in this area is carried by surface channels, so these streams may be even more important than sinks as contributors to FC loading during storm events. 


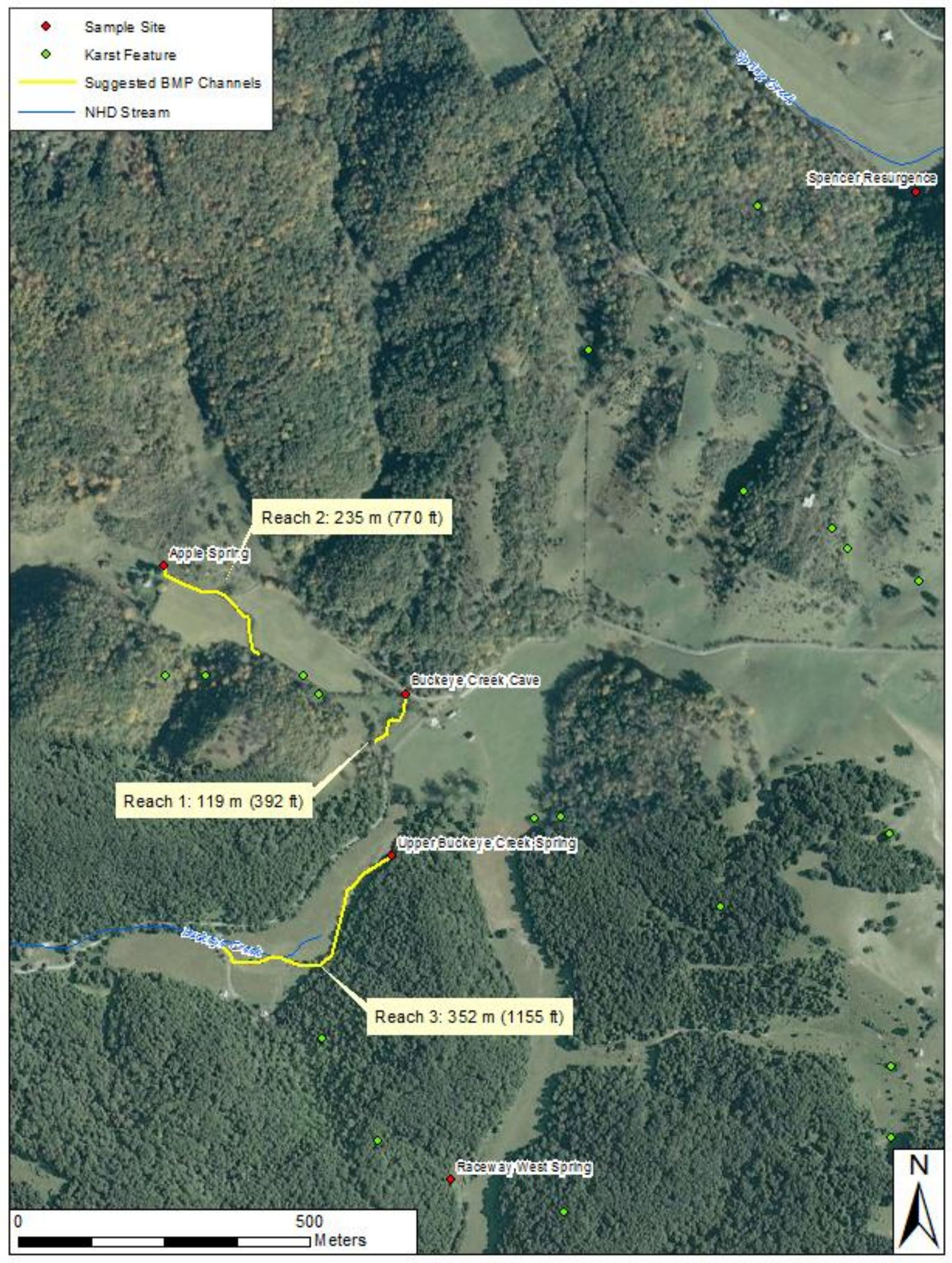

Figure 15: Locations of suggested surface channels for riparian BMPs. 
If agricultural contamination is still an issue in the basin after surface channel BMPs are implemented, BMPs should also be implemented at the important sinks (Deer Insurgence, Cluetown Pit, Short Stuff Cave, Turner Pit \#2, and the Hughes Springs insurgence). This study finds the major sinks in the basin to be second in priority for BMP implementation after the surface channels near Buckeye Creek Cave and Upper Buckeye Creek Spring because they are all directly connected to Apple Spring. Buckeye Creek Cave and Upper Buckeye Creek Spring are higher priorities for water quality improvement than Apple Spring. Because sinks are collecting points for surface runoff, BMPs at sinks can help control a large amount of non-point source contamination. Additionally, a BMP at a sink can treat runoff from a large area using relatively small area of land. Finally, if other steps are insufficient and resources are available, vegetated buffers and animal exclusion fences around smaller sinks located within the Racetrack, Buckeye Creek Valley, and Turner Hollow should be considered for BMP implementation. Examples of sink locations are also shown in Appendix F.

Vegetated riparian buffers and animal exclusion fences have been recommended as low cost BMPs in agricultural karst areas (Currens 2002). Simply fencing and then avoiding mowing near the stream can provide some vegetative protection in the riparian area if the landowner does not want to incur additional planning costs. Fencing can be inexpensive for the small areas needed (around \$1.50-\$2.00 per linear foot), but an alternative water source will also be needed if animals are excluded from water in the pasture (Lynch and Tjaden, 2000). Gravity fed water sources are cheapest and would likely work well in this area. An alternative water source could cost between $\$ 2000-\$ 4000$ for each pasture (Lynch and Tjaden, 2000). To help offset the costs, federal, state, and local funding is available from various programs for landowners implementing BMPs (WVDEP, 2012). 
BMP suggestions in this study are somewhat limited due to the extent of available research on BMP effectiveness in karst areas. Many BMPs have not been tested in karst areas, and only very few BMPs, have been developed specifically for use in karst areas. Further research in this field, including collection of baseline data and evaluation of BMP success would be useful, especially when the research can be used to evaluate whether government funding has been used effectively. Neill et al.(2003) demonstrated the importance of collecting baseline data prior to BMP implementation in order to facilitate future evaluation. Ideally, if BMPs are implemented in Buckeye Creek basin, baseline data from this study and others in the basin should be used to evaluate BMP effectiveness on a watershed scale.

\section{Implications of the Research}

The goal of this study was to complete a project that can serve as a guide for targeting critical contamination sources in other karst watersheds. Under time and data constraints typical of applied projects, the study demonstrates how stakeholders can make decisions in many karst watersheds. Conclusions formed by such a study may provide incentives for landowners to improve local water quality. For example, a farmer who knows that runoff from one pasture flows directly into a cattle trough in another pasture has great incentive to implement best management practices. Conclusions from this study and similar studies in other catchments could also help agencies to direct mitigation funds and efforts more efficiently. A greater improvement in water quality on the catchment scale could be gained from the same amount of effort by focusing conservation efforts at sites that contribute the most contamination. The BMP options and suggestions discussed in this study could raise awareness of the types of projects that could be beneficial in the future in this watershed and in similar agricultural karst basins. 
The prioritizing system used in this study is particular to this basin and this project, but may be modified or altered if a similar decision-making process is needed in another watershed. All stakeholders should be considered in the decision-making process and the importance of potential conservation projects may vary on an individual case basis. Outstanding factors that may override this ranking system could include a known habitat of an endangered species or other water uses that are not included in this study. Additionally, while fecal coliform bacteria was used as the major indicator of contamination in this study, other indicator contaminants could be used in other basins based on different contamination issues, land uses, or data collection capabilities. It should be noted that this study was conducted in a karst basin that is known to have conduit flow and close connections between surface and groundwater. This type of aquifer is vulnerable to groundwater contamination and is also likely to have flashy discharge and highly variable water chemistry (Shuster and White, 1971). The flow mechanics of the basin, relative vulnerability of the system, and transport mechanisms of the primary contaminants should all be considered when designing a sampling strategy or a similar prioritizing system in other karst basins.

The most important implication of this research is that it should encourage agencies, landowners, and other stakeholders to use some type of decision-making process and preemptive research to identify the most effective and efficient ways to improve water quality at the watershed level. Improved water quality can allow sustainable agricultural production in the basin without inordinate contamination. This approach to water quality improvement and protection benefits not only local water users, but also all downstream users and aquatic ecosystems. 


\section{Acknowledgements}

I would like to thank Doug Boyer and the USDA-ARS for providing data from The Hole and Buckeye Creek Basin, John Wirtz and the WVDEP for providing additional data from the West Virginia water quality assessment project, and John Tudek, George Dasher, and Dr. Gary Bissonnette for their advice and expertise. Special thanks to Dr. Bissonnette, Alex Kish, and the microbiology lab staff who have helped me and let me use the lab space and equipment necessary for fecal coliform testing, and to Derek Hall at the USDA-ARS lab in Beaver, West Virginia, who agreed to help with the chemical testing. Thanks to the landowners of Buckeye Creek basin who allowed data collection on their property. I would especially like to recognize Dr. Steve Kite, Dr. Dorothy Vesper, and Dr. Doug Boyer for their guidance on this project as committee members.

\section{References}

Alloush, G.A., D.G. Boyer, D.P. Belesky, and J.J. Halvorson. "Phosphorous Mobility in a Karst Landscape under Pasture Grazing System”. Agronomie, Vol. 23, 2003: 593-600.

American Public Health Association. Standard methods for the examination of water and wastewater. $18^{\text {th }}$ ed. APHA, Washington, D.C., 1992.

Ashton, K. "The analysis of flow data from karst drainage systems". Transactions Cave Research Group, Great Britain. Vol. 7, 1966: 161-203.

Barfield, B.J., G.K. Felton, E.W. Stevens, and M. McCann. "A simple model of karst spring flow using modified NRCS procedures”. Journal of Hydrology. Vol. 287, 2004: 34-48.

Bitton, G. Wastewater Microbiology. Wiley-Liss, New York, 1999: 781 pages.

Bolstad, Paul. GIS Fundamentals. $3^{\text {rd }}$ ed. Eider Press. White Bear Lake, MN, 2008.

Boyer, Douglas G. "Water quality improvement program effectiveness for carbonate aquifers in grazed land watersheds". Journal of the American Water Resources Association, April 2005: 291-300. 
Boyer, D.G. "Assessment of a sinkhole filter for removing agricultural contaminants" Journal of Soil and Water Conservation, Vol. 63, No. 1, 2008: 47-52.

Boyer, D.G. Sample Data from Buckeye Creek basin, collected from 1990-2009 by USDA-ARS in Beaver, WV. Unpublished.

Boyer, Douglas G. and Ewa Kuczynska. "Storm and seasonal distributions of fecal coliforms and Cryptosporidium in a spring". Journal of the American Water Resources Association, December 2003: 1449-1456.

Boyer, Doug and Pasquarell, Gary. "Nitrate concentrations in karst springs in an extensively grazed area". Water Resources Bulletin. Vol. 31, No. 4, 1995: 729-736.

Boyer, Douglas G. and Gary C. Pasquarell. "Agricultural Land Use Effects on Nitrate Concentrations in a Mature Karst Aquifer". Water Resources Bulletin. Vol. 32, No. 3, 1996: 565-573.

Boyer, D.G. and G.C. Pasquarell. "Agricultural land use impacts on bacterial water quality in a karst groundwater aquifer". Journal of the American Water Resources Association, Vol. 35, No. 2, April 1999: 291-300.

Cardwell, D.H., Erwin, R.B., and Woodward, H.P., Geologic Map of West Virginia, West Virginia Geological and Economic Survey, Map 1, scale 1:250,000. 1968.

Currens, James C. "Changes in groundwater quality in a conduit-flow dominated karst aquifer, following BMP implementation.” Environmental Geology, Vol. 45, 2002: 525-531.

Dasher, George R., and William M. Balfour. The Caves and Karst of the Buckeye Creek Basin, Greenbrier County, West Virginia. Maxwelton, W. Va.: West Virginia Association for Cave Studies, 1994: 238 pages.

Dasher, George R. and Doug Boyer. "Recent Spring Creek Area Dye Tracings: Greenbrier County, West Virginia". West Virginia Speleological Survey Monograph \#2. West Virginia Association for Cave Studies, 2000: 28 pages.

Dufour, Alfred P., Edley R. Strickland, and Victor J. Cabelli. "Membrane filter method for enumerating Escherichia coli". Applied and Environmental Microbiology, Vol. 41, No. 5, May 1981: 1152-1158.

Heller, Sara A. "A hydrogeologic study of the Greenbrier limestone karst of central Greenbrier County, West Virginia”. West Virginia University Theses, Geology, 1980: 204 pages.

Hipsey, Matthew R., Jason P. Antenucci, and Justin D. Brookes. "A generic, process-based model of microbial pollution in aquatic systems". Water Resources Research, Vol. 44, July 2008: 26 pages. 
Jones, William K. Karst Hydrology Atlas of West Virginia. Karst Waters Institute Special Publication 4, 1997: 111 pages.

Kleinjans, J.C., et al. "Nitrate contamination of drinking water: evaluation of genotoxic risk in human populations.” Environmental Health Perspectives. Vol. 94, 1991: 189-193.

Kvam, Paul H. and Brani Vidakovic. Nonparametric Statistics with Applications to Science and Engineering. John Wiley and Sons, Hoboken, NJ, 2007.

Lynch, Lori and Robert Tjaden. "When a Landowner Adopts a Riparian Buffer - Benefits and Costs". Maryland Cooperative Extension Fact Sheet 774. Maryland Cooperative Extension, 2000: 12 pages.

Madigan, M.T., J.M. Martinko, and J. Parker. Brock Biology of Microorganisms. Prentice Hall, Upper Saddle River, NJ, 2003: 1152 pages.

Mahler, B.J., J.-C. Personné, G.F. Lods, and C. Drogue. "Transport of free and particulateassociated bacteria in karst". Journal of Hydrology. Vol. 238, 2000: 179-193.

McColloch, Jane S. Springs of West Virginia:50 ${ }^{\text {th }}$ Anniversary Revised Edition. West Virginia Geological and Economic Survey, Volume V-6A, 1986: 493 pages.

Palmer, Arthur. Cave Geology. Cave Books, 2007: 389-394.

Pasquarell, G.C. and D.G. Boyer. "Agricultural Impacts on Bacterial Water Quality in Karst Groundwater”. Environmental Quality. Vol. 24, 1995: 959-969.

Petersen, Adam and Bruce Vondracek. "Water quality in relation to vegetative buffers around sinkholes in karst terrain". Journal of Soil and Water Conservation. Vol. 61, No. 6, 2006: 380-390.

Price, P.H. and Heck, E.T. "West Virginia Geological Survey: Greenbrier County”. Wheeling News Lithograph Company, Wheeling, WV, 1939: 846 pages.

Ryan, Martin and Joe Meiman. "An examination of short-term variations in water quality at a karst spring in Kentucky”. Ground Water. Vol. 34, No. 1, 1996: 23-30.

Shuster, Evan T. and William B. White. "Seasonal fluctuations in the chemistry of limestone springs: A possible means for characterizing carbonate aquifers". Journal of Hydrology. Vol. 14, Issue 2, November 1971: 93-128.

Spellman, Frank R. Stream Ecology and Self-Purification: An Introduction for Wastewater and Water Specialists. Lancaster, Pennsylvania: Technomic Publishing, 1996: 133 pages. 
Springer, Greg. "Southeastern Friends of the Pleistocene Fall 2002 Fieldtrip Guidebook". West Virginia Speleological Survey Monograph \#3. Athens, Ohio: Ohio University, 2002: 109 pages.

Tudek, John K. Digital Geologic Map of Buckeye Creek Basin, Unpublished.

United States Environmental Protection Agency. "Basic Information about E. coli 0157:H7 in Drinking Water". Office of Water Publications.

<http://water.epa.gov/drink/contaminants/basicinformation/ecoli.cfm>, 2006.

United States Environmental Protection Agency. "West Virginia 2008 Water Quality Assessment Report".

<http://iaspub.epa.gov/waters10/attains_index.control?p_area=WV>, 2010.

United States Geological Survey. National Elevation Dataset (NAD 83). <http://ned.usgs.gov/>, 2006.

United States Geological Survey. National Field Manual for the Collection of Water-Quality Data. <http://water.usgs.gov/owq/FieldManual/>, February 2008.

United States Geological Survey. National Water Information System: Current Conditions for West Virginia. <http://waterdata.usgs.gov/wv/nwis/current/?type=flow>, 2011.

United States Geologic Survey Land Cover Institute (LCI). National Land Cover Database. <http://www.mrlc.gov/>, 2001.

Veni, George. "GIS Applications in Managing Karst Groundwater and Biological Resources". Proceedings of the $9^{\text {th }}$ Multidisciplinary Conference on Sinkholes and the Engineering and Environmental Impacts of Karst. American Society of Civil Engineers, 2004: 466476.

White, William. Geomorphology and Hydrology of Karst Terrains. Oxford University Press, 1988: 355-405.

West Virginia Department of Environmental Protection Division of Water and Waste Management. West Virginia Integrated Water Quality Monitoring and Assessment Report. <http://www.dep.wv.gov/WWE/watershed/IR/Documents/WV_IR_2008_Report _Only_EPE_Approved.pdf $>, 2008$.

West Virginia Department of Environmental Protection Division of Water and Waste Management. West Virginia Integrated Water Quality Monitoring and Assessment Report. <http://www.deq.state.va.us/wqa/ir2010.html>, 2010. 
West Virginia Department of Environmental Protection Division of Water and Waste Management. Nonpoint Source Program. <http://www.dep.wv.gov/WWE/Programs/nonptsource/Pages/home.aspx>, 2012.

Younos, Tamim, Fred W. Kaurish, Terri Brown, and Raymond de Leon. "Determining the source of stream contamination in a karst-water system, southwest Virginia, USA". Journal of the American Water Resources Association. Vol. 37, No. 2. 2001: 327-334. 


\section{Appendix A: West Virginia Department of Environmental Protection Data}

West Virginia Department of Environmental Protection (WVDEP) samples from Spring Creek were collected near the mouth at the confluence with the Greenbrier River. This point is downstream from the locations where drainage from Buckeye Creek basin, The Hole basin, and Culverson Creek basin enter Spring Creek. Therefore, these samples show a collection of drainage, and contamination, from the three basins along with Spring Creek basin. The samples from Culverson Creek and Burns Run represent contributions to Spring Creek from outside of the Buckeye Creek basin. Locust Creek enters the Greenbrier River upstream of drainage from Spring Creek, and thus represents a contribution to the Greenbrier River outside of the Spring Creek basin.

Table A-1. 2008 Integrated Water Quality Assessment and Monitoring Report Listings for 305(b) Listed Streams:

\begin{tabular}{|c|c|c|}
\hline Stream Name & 2008 Status & Listed Cause of Impairment \\
\hline Spring Creek & $\begin{array}{l}\text { Entire length impaired for } \\
\text { public water supply and } \\
\text { recreation uses. }\end{array}$ & $\begin{array}{l}\text { Pathogens - Fecal Coliform } \\
\text { (Non-Point Source) }\end{array}$ \\
\hline Locust Creek & $\begin{array}{l}\text { Entire length good for all } \\
\text { designated uses }\end{array}$ & None \\
\hline
\end{tabular}

Table A-2. Additional Data for Listed and Unlisted Streams:

Spring Creek (Mile Point 0.1, near mouth)

\begin{tabular}{|c|c|c|c|c|c|}
\hline Date & pH & $\begin{array}{c}\text { Temperature } \\
\left({ }^{\circ} \mathrm{C}\right)\end{array}$ & $\begin{array}{l}\text { Spec. Cond. } \\
(\mu \mathrm{mhos} / \mathrm{cm})\end{array}$ & $\begin{array}{c}\text { Dissolved } \\
\text { Oxygen }(\mathrm{mg} / \mathrm{l}) \\
\end{array}$ & $\begin{array}{l}\text { Fecal Coliform } \\
\text { (CFU/100ml) }\end{array}$ \\
\hline $7 / 20 / 1999^{1}$ & 8.20 & 24.10 & 201 & 10.90 & 159 \\
\hline $6 / 28 / 2004$ & 8.29 & 17.28 & 200 & 10.37 & 88 \\
\hline $8 / 9 / 2004$ & 8.38 & 19.73 & 181 & 9.21 & 150 \\
\hline $9 / 8 / 2004$ & 7.35 & 15.67 & 116 & 7.78 & 4800 \\
\hline $10 / 28 / 2004$ & 7.12 & 11.46 & 143 & 9.32 & 360 \\
\hline $11 / 8 / 2004$ & 7.44 & 11.13 & 140 & 10.77 & 270 \\
\hline $11 / 29 / 2004$ & 7.22 & 8.58 & 133 & 10.93 & 590 \\
\hline $1 / 10 / 2005$ & 7.50 & 7.99 & 131 & 11.52 & 16 \\
\hline $1 / 31 / 2005$ & 8.08 & 5.13 & 152 & 12.84 & $<2$ \\
\hline $3 / 1 / 2005$ & 7.62 & 5.05 & 149 & 10.55 & $<2$ \\
\hline $4 / 4 / 2005$ & 7.43 & 9.12 & 113 & 10.20 & 400 \\
\hline $5 / 23 / 2005$ & 7.88 & 14.12 & 136 & 10.54 & 900 \\
\hline
\end{tabular}

${ }^{1} 1999$ Sample was taken at mile point 0.2 , All other samples were taken downstream at mile point 0.1 Means of other variables measured in 1999 sample included Hardness $(87.89 \mathrm{mg} / \mathrm{l})$, TSS $(<5 \mathrm{mg} / \mathrm{l})$, NO2-NO3-N (0.483 mg/l), N Total (0.983 mg/l), Ca Total $(28.9 \mathrm{mg} / \mathrm{l}), \mathrm{Mg}$ Total $(3.82 \mathrm{mg} / \mathrm{l})$ 
Culverson Creek (Mile Point 5.8, southeast of Williamsburg)

\begin{tabular}{|c|c|r|r|r|r|}
\hline Date & pH & $\begin{array}{c}\text { Temperature } \\
\left({ }^{\circ} \mathbf{C}\right)\end{array}$ & $\begin{array}{c}\text { Spec. Cond. } \\
(\boldsymbol{\mu m h o s} / \mathbf{c m})\end{array}$ & $\begin{array}{c}\text { Dissolved Oxygen } \\
(\mathbf{m g} / \mathbf{l})\end{array}$ & $\begin{array}{c}\text { Fecal Coliform } \\
(\mathbf{C o l o n i e s} / \mathbf{1 0 0 m})\end{array}$ \\
\hline $7 / 12 / 1999$ & 7.50 & 17.40 & 263 & 7.80 & 320 \\
\hline $7 / 11 / 2000^{1}$ & 7.73 & 18.73 & 169 & 9.06 & not measured \\
\hline $12 / 12 / 2000^{1}$ & 7.18 & 1.99 & 143 & 14.25 & not measured \\
\hline $4 / 3 / 2001^{1}$ & 7.68 & 6.58 & 120 & 10.94 & not measured \\
\hline
\end{tabular}

${ }^{1}$ Other measured variables included TSS, Cs, Mg, N, Hardness; fecal coliform levels were NOT measured for these dates

Burns Run (Mile Point 0.4, near mouth)

\begin{tabular}{|c|c|r|r|r|r|}
\hline Date & pH & $\begin{array}{c}\text { Temperature } \\
\left({ }^{\circ} \mathbf{C}\right)\end{array}$ & $\begin{array}{c}\text { Spec. Cond. } \\
(\boldsymbol{\mu m h o s} / \mathbf{c m})\end{array}$ & $\begin{array}{c}\text { Dissolved Oxygen } \\
(\mathbf{m g} / \mathbf{l})\end{array}$ & $\begin{array}{c}\text { Fecal Coliform } \\
(\mathbf{C F U} / \mathbf{1 0 0 m})\end{array}$ \\
\hline $10 / 11 / 2007$ & 7.48 & 12.76 & 226 & 7.40 & not measured \\
\hline
\end{tabular}

Burns Run (Mile Point 1.3, upstream of Spruce Run)

\begin{tabular}{|c|c|r|r|r|r|}
\hline Date & $\mathbf{p H}$ & $\begin{array}{c}\text { Temperature } \\
\left({ }^{\circ} \mathbf{C}\right)\end{array}$ & $\begin{array}{c}\text { Spec. Cond. } \\
(\boldsymbol{\mu m h o s} / \mathbf{c m})\end{array}$ & $\begin{array}{c}\text { Dissolved Oxygen } \\
(\mathbf{m g} / \mathbf{l})\end{array}$ & $\begin{array}{c}\text { Fecal Coliform } \\
(\mathbf{C F U} / \mathbf{1 0 0 m})\end{array}$ \\
\hline $10 / 11 / 2007$ & 6.47 & 13.88 & 242 & 5.08 & not measured \\
\hline
\end{tabular}

Locust Creek (Mile Point 1.3)

\begin{tabular}{|c|r|r|r|r|r|}
\hline Date & $\mathbf{p H}$ & $\begin{array}{c}\text { Temperature } \\
\left({ }^{\circ} \mathbf{C}\right)\end{array}$ & $\begin{array}{c}\text { Spec. Cond. } \\
(\boldsymbol{\mu m h o s} / \mathbf{c m})\end{array}$ & $\begin{array}{c}\text { Dissolved Oxygen } \\
(\mathbf{m g} / \mathbf{l})\end{array}$ & $\begin{array}{c}\text { Fecal Coliform } \\
(\mathbf{C F U} / \mathbf{1 0 0 m l})\end{array}$ \\
\hline $7 / 20 / 1999$ & - & 20.60 & 257 & 8.70 & 245 \\
\hline $9 / 20 / 2007$ & 8.08 & 16.05 & 315 & 8.77 & not measured \\
\hline
\end{tabular}

Source: WVDEP Watershed Assessment Program Data (WVDEP, 2008). 


\section{Appendix B: USDA-ARS Data}

Samples for The Hole basin were taken from Burns Cave, the main resurgence for the basin, and were collected and analyzed between June 1990 to January 2009. Grab samples were taken weekly or biweekly for most of this time, monthly from January 2005 through October 2006, and sporadically after May 2008. These samples were analyzed for fecal coliform density, total suspended sediment (TSS), chloride, nitrite, nitrate, phosphate, sulfate, sodium, ammonium, potassium, magnesium, and calcium. A number of samples were also collected by autosampler during storm events and analyzed for the same variables beginning in September 1999 (Boyer, unpublished).

Samples collected in the Buckeye Creek basin were analyzed for the same variables as The Hole basin samples. Buckeye Creek samples were collected in Buckeye Creek Cave at a point near the entrance, a point $\sim 180 \mathrm{~m}(600 \mathrm{ft})$ downstream of the entrance but upstream from a major inflow and upstream of the Watergate, and a third point downstream of the inflow approximately $30 \mathrm{~m}$ (100 ft) past the Watergate (Figure 4). Grab samples were taken in Buckeye Creek Cave approximately biweekly from September 2002 to November 2003 for the point at the entrance and the point upstream of the Watergate. Samples at the point downstream of the Watergate were collected from August 2000 to June 2002. Autosamplers were also used in Buckeye Creek, but storm samples were not analyzed for fecal coliform density because autosamplers could not be reached until the stormflow subsided. Buckeye Creek storm samples were analyzed for anions, cations, and TSS (Boyer, unpublished).

Table B-1: The Hole Basin (Burn's Cave Resurgence) Fecal Coliform Data.

\begin{tabular}{|c|c|c|}
\hline Site ID & Date & $\begin{array}{c}\text { Fecal } \\
\text { Coliform } \\
(\mathrm{CFU} / 100 \mathrm{ml})\end{array}$ \\
\hline $\mathrm{bc}^{*}$ & 07-Jun-90 & 230 \\
\hline $\mathrm{bc}$ & 19-Jun-90 & 520 \\
\hline $\mathrm{bc}$ & 26-Jun-90 & 620 \\
\hline $\mathrm{bc}$ & 03-Jul-90 & 26 \\
\hline $\mathrm{bc}$ & 10-Jul-90 & 186 \\
\hline $\mathrm{bc}$ & 17-Jul-90 & 3540 \\
\hline $\mathrm{bc}$ & 24-Jul-90 & 300 \\
\hline $\mathrm{bc}$ & 31-Jul-90 & 47 \\
\hline $\mathrm{bc}$ & 14-Aug-90 & 3200 \\
\hline $\mathrm{bc}$ & 21-Aug-90 & 87 \\
\hline $\mathrm{bc}$ & 28-Aug-90 & 480 \\
\hline $\mathrm{bc}$ & 04-Sep-90 & 138 \\
\hline $\mathrm{bc}$ & 11-Sep-90 & 125 \\
\hline $\mathrm{bc}$ & 18-Sep-90 & 25 \\
\hline $\mathrm{bc}$ & 25-Sep-90 & 88 \\
\hline $\mathrm{bc}$ & $02-O c t-90$ & 50 \\
\hline $\mathrm{bc}$ & 16-Oct-90 & 1163 \\
\hline $\mathrm{bc}$ & 23-Oct-90 & 6680 \\
\hline $\mathrm{bc}$ & $30-$ Oct-90 & 75 \\
\hline
\end{tabular}

Table B-2: Buckeye Creek Fecal Coliform Data.

\begin{tabular}{|l|r|r|}
\hline \multicolumn{1}{|c|}{ Site ID } & \multicolumn{1}{c|}{ Date } & $\begin{array}{c}\text { Fecal } \\
\text { Coliform } \\
\text { (CFU/100ml) }\end{array}$ \\
\hline buck ds* & 31-Aug-00 & 128 \\
\hline buck ds & 07-Sep-00 & 43 \\
\hline buck ds & $14-$ Sep-00 & 680 \\
\hline buck ds & 26-Oct-00 & 43 \\
\hline buck ds & 15-Nov-00 & 96 \\
\hline buck ds & 07-Feb-01 & 50 \\
\hline buck ds & 16-Feb-01 & 200 \\
\hline buck ds & 21-Feb-01 & 43 \\
\hline buck ds & 26-Apr-01 & 144 \\
\hline buck ds & 03-Aug-01 & 347 \\
\hline buck ds & 27-Sep-01 & 229 \\
\hline buck ds & 30-Jan-02 & 96 \\
\hline buck ds & 06-Mar-02 & 5 \\
\hline buck ds & 22-Mar-02 & 6 \\
\hline buck ds & 11-Apr-02 & 13 \\
\hline buck ds & 24-May-02 & 113 \\
\hline buck ds & 26-Jun-02 & 200 \\
\hline buck ent** & 26-Sep-02 & 500 \\
\hline buck ent & 30-Sep-02 & 980 \\
\hline
\end{tabular}


B-2

\begin{tabular}{|c|c|c|}
\hline $\mathrm{bc}$ & 06-Nov-90 & 138 \\
\hline bc & 13-Nov-90 & 808 \\
\hline $\mathrm{bc}$ & 21-Nov-90 & 67 \\
\hline $\mathrm{bc}$ & 27-Nov-90 & 25 \\
\hline $\mathrm{bc}$ & 03-Dec-90 & 50 \\
\hline $\mathrm{bc}$ & 11-Dec-90 & 20 \\
\hline $\mathrm{bc}$ & 26-Dec-90 & 183 \\
\hline $\mathrm{bc}$ & 02-Jan-91 & 75 \\
\hline $\mathrm{bc}$ & 08-Jan-91 & 825 \\
\hline $\mathrm{bc}$ & 15-Jan-91 & 8 \\
\hline $\mathrm{bc}$ & 23-Jan-91 & 33 \\
\hline $\mathrm{bc}$ & 29-Jan-91 & 91 \\
\hline $\mathrm{bc}$ & 05-Feb-91 & 73 \\
\hline $\mathrm{bc}$ & 12-Feb-91 & 100 \\
\hline $\mathrm{bc}$ & 19-Feb-91 & 184 \\
\hline $\mathrm{bc}$ & 26-Feb-91 & 28 \\
\hline $\mathrm{bc}$ & 18-Mar-91 & 264 \\
\hline $\mathrm{bc}$ & 26-Mar-91 & 440 \\
\hline $\mathrm{bc}$ & 02-Apr-91 & 140 \\
\hline $\mathrm{bc}$ & 09-Apr-91 & 108 \\
\hline $\mathrm{bc}$ & 23-Apr-91 & 52 \\
\hline $\mathrm{bc}$ & 30-Apr-91 & 59 \\
\hline $\mathrm{bc}$ & 07-May-91 & 47 \\
\hline $\mathrm{bc}$ & 14-May-91 & 63 \\
\hline $\mathrm{bc}$ & 21-May-91 & 50 \\
\hline $\mathrm{bc}$ & 28-May-91 & 500 \\
\hline $\mathrm{bc}$ & 04-Jun-91 & 43 \\
\hline $\mathrm{bc}$ & 11-Jun-91 & 45 \\
\hline $\mathrm{bc}$ & 18-Jun-91 & 73 \\
\hline $\mathrm{bc}$ & 02-Jul-91 & 1000 \\
\hline $\mathrm{bc}$ & 09-Jul-91 & 124 \\
\hline $\mathrm{bc}$ & 16-Jul-91 & 32 \\
\hline $\mathrm{bc}$ & 23-Jul-91 & 20 \\
\hline $\mathrm{bc}$ & 30-Jul-91 & 87 \\
\hline $\mathrm{bc}$ & 06-Aug-91 & 88 \\
\hline $\mathrm{bc}$ & 13-Aug-91 & 77 \\
\hline $\mathrm{bc}$ & 20-Aug-91 & 96 \\
\hline $\mathrm{bc}$ & 27-Aug-91 & 45 \\
\hline $\mathrm{bc}$ & 03-Sep-91 & 21 \\
\hline $\mathrm{bc}$ & 10-Sep-91 & 29 \\
\hline $\mathrm{bc}$ & 17-Sep-91 & 11 \\
\hline $\mathrm{bc}$ & 24-Sep-91 & 5 \\
\hline $\mathrm{bc}$ & 08-Oct-91 & 0 \\
\hline $\mathrm{bc}$ & 15-Oct-91 & 7 \\
\hline $\mathrm{bc}$ & 22-Oct-91 & 5 \\
\hline $\mathrm{bc}$ & 05-Nov-91 & 1 \\
\hline $\mathrm{bc}$ & 19-Nov-91 & 2 \\
\hline $\mathrm{bc}$ & 26-Nov-91 & 149 \\
\hline $\mathrm{bc}$ & 10-Dec-91 & 440 \\
\hline
\end{tabular}

\begin{tabular}{|c|c|c|}
\hline buck ent & 10-Oct-02 & 360 \\
\hline buck ent & 17-Oct-02 & 1180 \\
\hline buck ent & 21-Oct-02 & 380 \\
\hline buck ent & 15-Nov-02 & 39 \\
\hline buck ent & 22-Nov-02 & 31 \\
\hline buck ent & 26-Nov-02 & 57 \\
\hline buck ent & 30-Jan-03 & 8 \\
\hline buck ent & 31-Jan-03 & 3 \\
\hline buck ent & 05-Feb-03 & 10 \\
\hline buck ent & 26-Feb-03 & 20 \\
\hline buck ent & 17-Apr-03 & 25 \\
\hline buck ent & 21-Apr-03 & 310 \\
\hline buck ent & 24-Apr-03 & 27 \\
\hline buck ent & 11-Jun-03 & 80 \\
\hline buck ent & 12-Jun-03 & 136 \\
\hline buck ent & 17-Jun-03 & 1000 \\
\hline buck ent & 18-Jun-03 & 1060 \\
\hline buck ent & 23-Jun-03 & 56 \\
\hline buck ent & 26-Jun-03 & 860 \\
\hline buck ent & 03-Jul-03 & 1000 \\
\hline buck ent & 10-Jul-03 & 1940 \\
\hline buck ent & 14-Jul-03 & 128 \\
\hline buck ent & 06-Aug-03 & 1400 \\
\hline buck ent & 13-Aug-03 & 6100 \\
\hline buck ent & 14-Aug-03 & 1364 \\
\hline buck ent & 04-Sep-03 & 420 \\
\hline buck ent & 08-Sep-03 & 320 \\
\hline buck ent & 25-Sep-03 & 1060 \\
\hline buck ent & 24-Oct-03 & 23 \\
\hline buck ent & 30-Oct-03 & 112 \\
\hline buck ent & 07-Nov-03 & 2020 \\
\hline buck ent & 26-Nov-03 & 92 \\
\hline buck us*** & 25-Sep-02 & 1840 \\
\hline buck us & 26-Sep-02 & 360 \\
\hline buck us & 27-Sep-02 & 7000 \\
\hline buck us & 30-Sep-02 & 1140 \\
\hline buck us & 09-Oct-02 & 20 \\
\hline buck us & $17-$ Oct-02 & 1360 \\
\hline buck us & 21-Oct-02 & 217 \\
\hline buck us & 01-Nov-02 & 180 \\
\hline buck us & 15-Nov-02 & 39 \\
\hline buck us & 22-Nov-02 & 55 \\
\hline buck us & 30-Jan-03 & 10 \\
\hline buck us & 31-Jan-03 & 0 \\
\hline buck us & 26-Feb-03 & 20 \\
\hline buck us & 17-Apr-03 & 40 \\
\hline buck us & 24-Apr-03 & 60 \\
\hline buck us & 11-Jun-03 & 200 \\
\hline buck us & 23-Jun-03 & 56 \\
\hline
\end{tabular}


B-3

\begin{tabular}{|c|c|c|}
\hline $\mathrm{bc}$ & 17-Dec-91 & 400 \\
\hline $\mathrm{bc}$ & 31-Dec-91 & 250 \\
\hline $\mathrm{bc}$ & 07-Jan-92 & 86 \\
\hline $\mathrm{bc}$ & 14-Jan-92 & 32 \\
\hline $\mathrm{bc}$ & 21-Jan-92 & 20 \\
\hline $\mathrm{bc}$ & 28-Jan-92 & 37 \\
\hline $\mathrm{bc}$ & 04-Feb-92 & 23 \\
\hline $\mathrm{bc}$ & 11-Feb-92 & 47 \\
\hline $\mathrm{bc}$ & 18-Feb-92 & 149 \\
\hline $\mathrm{bc}$ & 25-Feb-92 & 600 \\
\hline $\mathrm{bc}$ & 03-Mar-92 & 38 \\
\hline $\mathrm{bc}$ & 10-Mar-92 & 540 \\
\hline $\mathrm{bc}$ & 17-Mar-92 & 100 \\
\hline $\mathrm{bc}$ & 24-Mar-92 & 224 \\
\hline $\mathrm{bc}$ & 31-Mar-92 & 32 \\
\hline $\mathrm{bc}$ & 07-Apr-92 & 156 \\
\hline $\mathrm{bc}$ & 14-Apr-92 & 49 \\
\hline $\mathrm{bc}$ & 28-Apr-92 & 370 \\
\hline $\mathrm{bc}$ & 05-May-92 & 117 \\
\hline $\mathrm{bc}$ & 12-May-92 & 320 \\
\hline $\mathrm{bc}$ & 19-May-92 & 370 \\
\hline \multicolumn{3}{|c|}{ Data omitted $^{1}$} \\
\hline bc 1815 & 11-Dec-08 & 1200 \\
\hline bc 1900 & 11-Dec-08 & 0 \\
\hline bc 1945 & 11-Dec-08 & 50 \\
\hline bc 2030 & 11-Dec-08 & 200 \\
\hline bc 2115 & 11-Dec-08 & 100 \\
\hline bc 2200 & 11-Dec-08 & 350 \\
\hline bc 2245 & 11-Dec-08 & 700 \\
\hline bc 2330 & 11-Dec-08 & 500 \\
\hline bc 0015 & 12-Dec-08 & 1600 \\
\hline bc 0100 & 12-Dec-08 & 650 \\
\hline bc 0145 & 12-Dec-08 & 1150 \\
\hline bc 0230 & 12-Dec-08 & 1500 \\
\hline bc 0315 & 12-Dec-08 & 1900 \\
\hline bc 0400 & 12-Dec-08 & 1300 \\
\hline bc 0445 & 12-Dec-08 & 2150 \\
\hline bc 0530 & 12-Dec-08 & 1700 \\
\hline bc 0615 & 12-Dec-08 & 1250 \\
\hline bc 0700 & 12-Dec-08 & 850 \\
\hline bc 0745 & 12-Dec-08 & 1300 \\
\hline bc 0830 & 12-Dec-08 & 2150 \\
\hline bc 0915 & 12-Dec-08 & 2100 \\
\hline bc 1000 & 12-Dec-08 & 2150 \\
\hline bc 1045 & 12-Dec-08 & 1750 \\
\hline bc 1130 & 12-Dec-08 & 1150 \\
\hline $\mathrm{bc}$ & 15-Dec-08 & 4160 \\
\hline bc 1015 & 07-Jan-09 & 1220 \\
\hline bc 1100 & 07-Jan-09 & 1500 \\
\hline
\end{tabular}

\begin{tabular}{|l|r|r|}
\hline buck us & 26-Jun-03 & 120 \\
\hline buck us & 03-Jul-03 & 2280 \\
\hline buck us & 14-Jul-03 & 128 \\
\hline buck us & 06-Aug-03 & 3160 \\
\hline buck us & 13-Aug-03 & 980 \\
\hline buck us & 04-Sep-03 & 540 \\
\hline buck us & $08-$ Sep-03 & 324 \\
\hline buck us & $25-$ Sep-03 & 220 \\
\hline buck us & 24-Oct-03 & 37 \\
\hline buck us & 30-Oct-03 & 152 \\
\hline buck us & $07-$ Nov-03 & 820 \\
\hline buck us & 26-Nov-03 & 80 \\
\hline
\end{tabular}

Avg. us

739.2

Avg. ds

143.3

Avg. ent

679.4
$* \mathrm{ds}=$ downstream sampling location
$* *$ ent $=$ Buckeye Creek Cave entrance
$* * *$ us $=$ upstream sampling location

Source: Boyer, unpublished data. 


\begin{tabular}{|l|r|r|}
\hline bc 1145 & 07-Jan-09 & 1460 \\
\hline bc 1230 & 07-Jan-09 & 1180 \\
\hline bc 1315 & 07-Jan-09 & 1960 \\
\hline bc 1400 & 07-Jan-09 & 1560 \\
\hline bc 1445 & 07-Jan-09 & 1540 \\
\hline bc 1530 & 07-Jan-09 & 2280 \\
\hline bc 1615 & 07-Jan-09 & 3560 \\
\hline bc 1700 & 07-Jan-09 & 1580 \\
\hline bc 1745 & 07-Jan-09 & 1540 \\
\hline bc 1830 & 07-Jan-09 & 1760 \\
\hline bc 1915 & 07-Jan-09 & 1420 \\
\hline bc 2000 & 07-Jan-09 & 1480 \\
\hline bc 2045 & 07-Jan-09 & 1400 \\
\hline bc 2130 & 07-Jan-09 & 1140 \\
\hline bc 2215 & 07-Jan-09 & 1640 \\
\hline bc & 09-Jan-09 & 408 \\
\hline Avg bc & & 23872 \\
\hline
\end{tabular}

Avg. bc

$* \mathrm{bc}=$ Burn's Cave

${ }^{1}$ Data from The Hole were truncated due to the large number of samples collected by autosampler. The entire data set was available for analysis in this study and is available from the USDA-ARS.

Source: Boyer, unpublished data. 


\section{Appendix C: Known Springs and Insurgences of Buckeye Creek Basin}

\begin{tabular}{|c|c|c|c|c|}
\hline \multirow[t]{2}{*}{ Feature Name } & \multirow[t]{2}{*}{$\begin{array}{c}\text { WVACS } \\
\text { ID } \\
\end{array}$} & \multirow[t]{2}{*}{$\begin{array}{c}\text { Elevation } \\
\text { (ft above } \\
\text { MSL) } \\
\end{array}$} & \multicolumn{2}{|c|}{ Location } \\
\hline & & & Latitude $(\mathrm{N})$ & Longitude $(\mathrm{W})$ \\
\hline Apple Spring & S1 & 1980 & $37^{\circ} 58^{\prime} 41^{\prime \prime}$ & $80^{\circ} 24^{\prime} 16^{\prime \prime}$ \\
\hline Beards Spring & S2 & 2250 & $37^{\circ} 56^{\prime} 51^{\prime \prime}$ & $80^{\circ} 23^{\prime} 35^{\prime \prime}$ \\
\hline Beaver Dam Insurgence & S4 & 1980 & $37^{\circ} 58^{\prime} 35^{\prime \prime}$ & $80^{\circ} 24^{\prime} 13^{\prime \prime}$ \\
\hline Boothe Seep & S3 & 2305 & $37^{\circ} 57^{\prime} 04^{\prime \prime}$ & $80^{\circ} 23^{\prime} 36^{\prime \prime}$ \\
\hline Briar Patch FRO & S5 & 2140 & $37^{\circ} 57^{\prime} 36^{\prime \prime}$ & $80^{\circ} 23^{\prime} 47^{\prime \prime}$ \\
\hline Callisons Hollow Spring (Cavelet Spring) & S6 & 2090 & $37^{\circ} 58^{\prime} 45^{\prime \prime}$ & $80^{\circ} 23^{\prime} 35^{\prime \prime}$ \\
\hline Callisons Pond Spring & S7 & 1990 & $37^{\circ} 58^{\prime} 21^{\prime \prime}$ & $80^{\circ} 23^{\prime} 17^{\prime \prime}$ \\
\hline Cannon Hole & S8 & 1855 & $37^{\circ} 59^{\prime} 00^{\prime \prime}$ & $80^{\circ} 22^{\prime} 31^{\prime \prime}$ \\
\hline Chestnut Rail Spring & S9 & 2360 & $37^{\circ} 56^{\prime} 38^{\prime \prime}$ & $80^{\circ} 23^{\prime} 24^{\prime \prime}$ \\
\hline $\begin{array}{l}\text { Circulating Cenote (Spring Creek Cenote) } \\
(\text { Cenotes \#3,\#4) }\end{array}$ & $\mathrm{S} 10$ & 1850 & $37^{\circ} 58^{\prime} 12^{\prime \prime}$ & $80^{\circ} 22^{\prime} 34^{\prime \prime}$ \\
\hline Cliff Spring & S11 & 1960 & $37^{\circ} 58^{\prime} 35^{\prime \prime}$ & $80^{\circ} 24^{\prime} 06^{\prime \prime}$ \\
\hline Dale's Spring & S12 & 1850 & $37^{\circ} 58^{\prime} 09^{\prime \prime}$ & $80^{\circ} 22^{\prime} 37^{\prime \prime}$ \\
\hline Deer Insurgence & S13 & 2030 & $37^{\circ} 58^{\prime} 38^{\prime \prime}$ & $80^{\circ} 24^{\prime} 32^{\prime \prime}$ \\
\hline Double Stream Cave & S14 & 2270 & $37^{\circ} 56^{\prime} 40^{\prime \prime}$ & $80^{\circ} 24^{\prime} 13^{\prime \prime}$ \\
\hline Double Tree Spring & S15 & 2200 & $37^{\circ} 57^{\prime} 02^{\prime \prime}$ & $80^{\circ} 24^{\prime} 00^{\prime \prime}$ \\
\hline Grapevine Cenote & S16 & 1850 & $37^{\circ} 58^{\prime} 12^{\prime \prime}$ & $80^{\circ} 22^{\prime} 32^{\prime \prime}$ \\
\hline Head of Hollow Spring & S17 & 2100 & $37^{\circ} 59^{\prime} 01^{\prime \prime}$ & $80^{\circ} 23^{\prime} 34^{\prime \prime}$ \\
\hline High Water Cenote \#1 & S18 & 1850 & $37^{\circ} 58^{\prime} 08^{\prime \prime}$ & $80^{\circ} 22^{\prime} 32^{\prime \prime}$ \\
\hline High Water Cenote \#2 & S19 & 1855 & $37^{\circ} 58^{\prime} 12^{\prime \prime}$ & $80^{\circ} 22^{\prime} 30^{\prime \prime}$ \\
\hline Hughes Cedar Spring & $\mathrm{S} 21$ & 2050 & $37^{\circ} 58^{\prime} 40^{\prime \prime}$ & $80^{\circ} 23^{\prime} 23^{\prime \prime}$ \\
\hline Hughes Spring & S20 & 2090 & $37^{\circ} 58^{\prime} 42^{\prime \prime}$ & $80^{\circ} 23^{\prime} 28^{\prime \prime}$ \\
\hline JJ Spring & $\mathrm{S} 22$ & 1850 & $37^{\circ} 58^{\prime} 12^{\prime \prime}$ & $80^{\circ} 22^{\prime} 29^{\prime \prime}$ \\
\hline Locust Spring & $\mathrm{S} 23$ & 2050 & $37^{\circ} 57^{\prime} 37^{\prime \prime}$ & $80^{\circ} 23^{\prime} 52^{\prime \prime}$ \\
\hline Long-Gone Sinkhole & $\mathrm{S} 24$ & 1855 & $37^{\circ} 58^{\prime} 13^{\prime \prime}$ & $80^{\circ} 22^{\prime} 34^{\prime \prime}$ \\
\hline Lower Cliff Spring & $\mathrm{S} 25$ & 1960 & $37^{\circ} 58^{\prime} 34^{\prime \prime}$ & $80^{\circ} 24^{\prime} 05^{\prime \prime}$ \\
\hline Lower Harrison Spring & S26 & 1980 & $37^{\circ} 58^{\prime} 15^{\prime \prime}$ & $80^{\circ} 24^{\prime} 05^{\prime \prime}$ \\
\hline Lower McFerrin Spring & S27 & 1850 & $37^{\circ} 57^{\prime} 59^{\prime \prime}$ & $80^{\circ} 22^{\prime} 41^{\prime \prime}$ \\
\hline Lower Turner Insurgence & S28 & 2050 & $37^{\circ} 58^{\prime} 02^{\prime \prime}$ & $80^{\circ} 24^{\prime} 01^{\prime \prime}$ \\
\hline McMillon Blue Hole & S29 & 1940 & $37^{\circ} 57^{\prime} 55^{\prime \prime}$ & $80^{\circ} 24^{\prime} 05^{\prime \prime}$ \\
\hline McMillon Insurgence & $\mathrm{S} 30$ & 1950 & $37^{\circ} 57^{\prime} 56^{\prime \prime}$ & $80^{\circ} 24^{\prime} 02^{\prime \prime}$ \\
\hline Midway Spring (Boil Hole FRO) & S31 & 1850 & $37^{\circ} 58^{\prime} 01^{\prime \prime}$ & $80^{\circ} 22^{\prime} 46^{\prime \prime}$ \\
\hline No Cave Springs & $\mathrm{S} 32$ & 1950 & 3759’04”' & $80^{\circ} 23^{\prime} 10^{\prime \prime}$ \\
\hline Oak Tree Spring & S33 & 2360 & $37^{\circ} 56^{\prime} 39^{\prime \prime}$ & $80^{\circ} 23^{\prime} 48^{\prime \prime}$ \\
\hline Osborne Insurgence & S34 & 2020 & $37^{\circ} 58^{\prime} 21^{\prime \prime}$ & $80^{\circ} 24^{\prime} 31^{\prime \prime}$ \\
\hline Osborne Spring & S35 & 2070 & $37^{\circ} 58^{\prime} 22^{\prime \prime}$ & $80^{\circ} 24^{\prime} 31^{\prime \prime}$ \\
\hline
\end{tabular}


C-2

\begin{tabular}{|c|c|c|c|c|}
\hline Quartet Spring & S36 & 1990 & $37^{\circ} 58^{\prime} 27^{\prime \prime}$ & $80^{\circ} 23^{\prime} 48^{\prime \prime}$ \\
\hline Raceway East Spring & S37 & 2010 & $37^{\circ} 58^{\prime} 05^{\prime \prime}$ & $80^{\circ} 23^{\prime} 48^{\prime \prime}$ \\
\hline Raceway West Spring & S38 & 2000 & $37^{\circ} 58^{\prime} 07^{\prime \prime}$ & $80^{\circ} 23^{\prime} 56^{\prime \prime}$ \\
\hline Railroad Crossing Spring & S39 & 1880 & $37^{\circ} 58^{\prime} 23^{\prime \prime}$ & $80^{\circ} 22^{\prime} 42^{\prime \prime}$ \\
\hline Reynolds Swallowhole & $\mathrm{S} 40$ & 2245 & $37^{\circ} 56^{\prime} 50^{\prime \prime}$ & $80^{\circ} 23^{\prime} 34^{\prime \prime}$ \\
\hline Rock Spring & S41 & 1980 & $37^{\circ} 58^{\prime} 35^{\prime \prime}$ & $80^{\circ} 24^{\prime} 16^{\prime \prime}$ \\
\hline Rocky Ravine Sink & $\mathrm{S} 42$ & 2270 & $37^{\circ} 56^{\prime} 51^{\prime \prime}$ & $80^{\circ} 23^{\prime} 35^{\prime \prime}$ \\
\hline Seep Cave \#1 & $\mathrm{S} 43$ & 2280 & $37^{\circ} 56^{\prime} 51^{\prime \prime}$ & $80^{\circ} 23^{\prime} 46^{\prime \prime}$ \\
\hline Shovel Spring & S44 & 2060 & $37^{\circ} 58^{\prime} 26^{\prime \prime}$ & $80^{\circ} 23^{\prime} 25^{\prime \prime}$ \\
\hline Sissler Spring & $\mathrm{S} 45$ & 2170 & $37^{\circ} 58^{\prime} 09^{\prime \prime}$ & $80^{\circ} 23^{\prime} 25^{\prime \prime}$ \\
\hline Thought-We-Had-It & $\mathrm{S} 46$ & 2050 & $37^{\circ} 58^{\prime} 56^{\prime \prime}$ & $80^{\circ} 23^{\prime} 00^{\prime \prime}$ \\
\hline Tree House Spring & S47 & 2105 & $37^{\circ} 58^{\prime} 49^{\prime \prime}$ & $80^{\circ} 23^{\prime} 14^{\prime \prime}$ \\
\hline Turner Pond Spring & $\mathrm{S} 48$ & 2070 & $37^{\circ} 58^{\prime} 09^{\prime \prime}$ & $80^{\circ} 24^{\prime} 01^{\prime \prime}$ \\
\hline Upper Buckeye Creek Spring & S49 & 1945 & $37^{\circ} 58^{\prime} 25^{\prime \prime}$ & $80^{\circ} 24^{\prime} 00^{\prime \prime}$ \\
\hline Upper Harrison Spring & $\mathrm{S} 50$ & 2020 & $37^{\circ} 58^{\prime} 13^{\prime \prime}$ & $80^{\circ} 23^{\prime} 25^{\prime \prime}$ \\
\hline Willow Cenote & S51 & 1915 & $37^{\circ} 59^{\prime} 14^{\prime \prime}$ & $80^{\circ} 23^{\prime} 42^{\prime \prime}$ \\
\hline Unnamed Spring & SU & 2250 & $37^{\circ} 57^{\prime} 12^{\prime \prime}$ & $80^{\circ} 23^{\prime} 15^{\prime \prime}$ \\
\hline
\end{tabular}

Data from Dasher and Balfour (1994) and McColloch (1986). WVACS ID denotes West Virginia Association for Cave Studies identifier. 
Appendix D: Study Sample Site Locations

\begin{tabular}{|l|l|l|l|l|}
\hline Spring Name & WVACS ID & $\begin{array}{l}\text { Elevation (feet } \\
\text { above MSL) }\end{array}$ & Latitude & Longitude \\
\hline Apple Spring & S1 & 1980 & $37^{\circ} 58^{\prime} 41^{\prime \prime} \mathrm{N}$ & $80^{\circ} 24^{\prime} 16^{\prime \prime} \mathrm{W}$ \\
\hline $\begin{array}{l}\text { Buckeye Creek Cave } \\
\text { Entrance }\end{array}$ & GBR0086-A & 1945 & $37^{\circ} 58^{\prime} 34^{\prime \prime} \mathrm{N}$ & $80^{\circ} 23^{\prime} 59^{\prime \prime} \mathrm{W}$ \\
\hline Circulating Cenote & S10 & 1850 & $37^{\circ} 58^{\prime} 12^{\prime \prime} \mathrm{N}$ & $80^{\circ} 22^{\prime} 34^{\prime \prime} \mathrm{W}$ \\
\hline Raceway East Spring & S37 & 2010 & $37^{\circ} 58^{\prime} 05^{\prime \prime} \mathrm{N}$ & $80^{\circ} 23^{\prime} 48^{\prime \prime} \mathrm{W}$ \\
\hline $\begin{array}{l}\text { Raceway West Spring } \\
\text { Spencer Cave }\end{array}$ & S38 & 2000 & $37^{\circ} 58^{\prime} 07^{\prime \prime} \mathrm{N}$ & $80^{\circ} 23^{\prime} 56^{\prime \prime} \mathrm{W}$ \\
\hline $\begin{array}{l}\text { Upper Buckeye Creek } \\
\text { Spring }\end{array}$ & S49 & 1920 & $37^{\circ} 59^{\prime} 02^{\prime \prime} \mathrm{N}$ & $80^{\circ} 23^{\prime} 23^{\prime \prime} \mathrm{W}$ \\
\hline Unnamed Spring* & SU & 1945 & $37^{\circ} 58^{\prime} 25^{\prime \prime} \mathrm{N}$ & $80^{\circ} 24^{\prime} 00^{\prime \prime} \mathrm{W}$ \\
\hline
\end{tabular}

Locations and elevations of sampling sites within Buckeye Creek basin. Data from Dasher and Balfour, 1994, and field visits as part of this study in May and July 2010. Dasher and Balfour Data are NAD 1927, Murphy data (denoted by asterisk) are NAD 1983.

\section{Site Descriptions:}

Apple Spring:

Apple Spring flows out from under a large block of limestone. Water has been traced from Nellie's Cave, the Deer Insurgence, and Turner Pit \#2. Water flows into the Buckeye Creek Cave Overflow and Buckeye Creek Cave.

Buckeye Creek Cave Entrance:

The surface channel of Buckeye Creek enters Buckeye Creek Cave at this entrance and flow becomes entirely subsurface. The entrance is a large triangular opening in a fenced pasture that is currently grazed by horses.

Circulating Cenote:

The Circulating Cenote is a large spring with a diameter of approximately $30 \mathrm{~m}$ (100 feet). The Circulating Cenote is outside of the Buckeye Creek surface basin and is fed by the Friars Hole Cave System via Cannon Hole, and other caves along upper Spring Creek. Water in the Circulating Cenote resurges into a large pool from Cenote \#4 and resurges into Cenote \#3. 
Water from Cenote \#3 resurges at the Grapevine Cenote and JJ Spring, on the opposite side of Spring Creek.

\section{Raceway East Spring:}

Raceway East Spring is on the east side of the Racetrack. Raceway East Spring is fairly small, flowing out of an approximately 2 by 6 inch hole, but other wet weather springs appear to be located nearby. Water flows into the Racetrack, which drains to Buckeye Creek before it enters Buckeye Creek Cave.

Raceway West Spring:

Raceway West Spring is located on the west side of the Racetrack. The water from the spring flows through a water line approximately 120 feet downhill to feed a pond in a cattle pasture. Any overflow or seepage from the pond is likely to flow downstream to Buckeye Creek and into Buckeye Creek Cave.

Spencer Resurgence:

Spencer Resurgence is the outlet of Buckeye Creek Basin into Spring Creek. The resurgence is located immediately above Spring Creek on a steep hillside behind the West Virginia Association for Cave Studies (WVACS) field house. In wet weather, the resurgence forms a waterfall flowing from an entrance of Spencer Cave, and in dryer times the resurgence forms a seep from rocks below the cave entrance. The resurgence is located above a cattle pasture.

\section{Upper Buckeye Creek Spring:}

Upper Buckeye Creek Spring emerges on the south side of the Buckeye Creek valley immediately down valley from Upper Buckeye Creek Cave. Water flows on the surface for several hundred feet then flows into Buckeye Creek Cave.

\section{Unnamed Spring:}

This spring is located off an old logging road in the southeastern part of the basin near Boothe Hollow. The spring emerges beneath a limestone outcrop and creates a small surface stream. The spring is in an area that has been cleared for logging and rural development but is not currently used for pasture. 


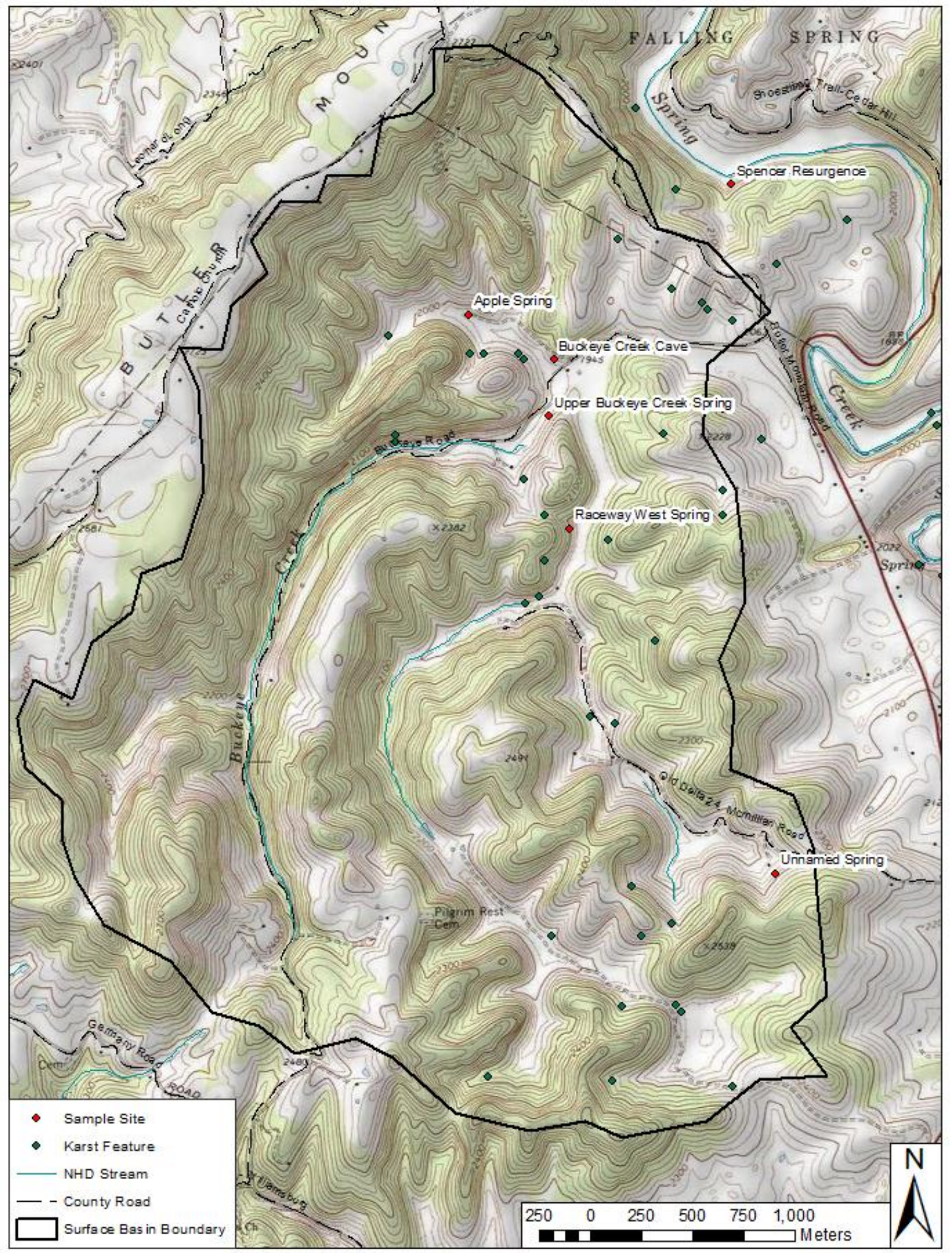

Figure D1: Map showing sampling site locations and karst features of Buckeye Creek watershed (based on data from Dasher and Balfour 1994 and field observations for this study in May and July 2010). 


\section{Appendix E: Previous Dye Traces and Subsurface Connections}

\begin{tabular}{|c|c|c|}
\hline Insurgence (Dye released) & Resurgence (Dye captured) & Dye Trace Source \\
\hline Spout Cave & $\begin{array}{l}\text { McMillon Blue Hole } \\
\text { Upper Buckeye Cave }\end{array}$ & $\begin{array}{l}\text { Jones 1994, published in Dasher } \\
\text { and Balfour } 1994\end{array}$ \\
\hline Deer Insurgence & Apple Spring & $\begin{array}{l}\text { Balfour 1994, published in } \\
\text { Dasher and Balfour } 1994\end{array}$ \\
\hline Above Deer Insurgence & Rock Spring & $\begin{array}{l}\text { Balfour 1994, published in } \\
\text { Dasher and Balfour } 1994\end{array}$ \\
\hline Short Stuff Cave & Apple Spring & $\begin{array}{l}\text { Balfour 1994, published in } \\
\text { Dasher and Balfour } 1994\end{array}$ \\
\hline Pilgrim's Rest Cave & Culverson Springs & $\begin{array}{l}\text { Balfour 1994, published in } \\
\text { Dasher and Balfour } 1994\end{array}$ \\
\hline Fuells Fruit Cave & Cliff Spring & Dasher and Boyer 2000 \\
\hline Turner Pit \#2 & Apple Spring & Dasher and Boyer 2000 \\
\hline Baber Pit \#2 & Callisons Pond & Dasher and Boyer 2000 \\
\hline Sissler Spring & Callisons Pond & Dasher and Boyer 2000 \\
\hline Callisons Pond Cave & $\begin{array}{l}\text { Spring Creek northeast of } \\
\text { Callisons Pond Cave }\end{array}$ & Dasher and Boyer 2000 \\
\hline Spout Cave & Upper Buckeye Cave & Dasher and Boyer 2000 \\
\hline Osbourne Insurgence & Fuells Fruit Cave & Dasher and Boyer 2000 \\
\hline Beaver Dam Insurgence & Cliff Spring & Dasher and Boyer 2000 \\
\hline Reynolds Swallowhole & Boggs Blue Hole & Dasher and Boyer 2000 \\
\hline Double Stream Cave & Culverson Springs & Dasher and Boyer 2000 \\
\hline Tin Cave & Culverson Springs & Dasher and Boyer 2000 \\
\hline Reynolds Swallowhole & Burns Cave \#2 & Dasher and Boyer 2000 \\
\hline Locust Spring Cave \#2 & Upper Buckeye Cave & Dasher and Boyer 2000 \\
\hline Boothe Cave & Culverson Springs & Dasher and Boyer 2000 \\
\hline
\end{tabular}


E-2

\begin{tabular}{|l|l|l|}
\hline Seep Cave \#2 & Culverson Springs & Dasher and Boyer 2000 \\
\hline Callisons Pond Cave & Rubble Spring & Dasher and Boyer 2000 \\
\hline Hughes Sink & Buckeye Creek Cave & Dasher and Boyer 2000 \\
\hline Old School Cave & Buckeye Creek Cave & Dasher and Boyer 2000 \\
\hline Cluetown Pit & Rock Spring & Dasher and Boyer 2000 \\
\hline
\end{tabular}




\section{Appendix F: Site Photos}

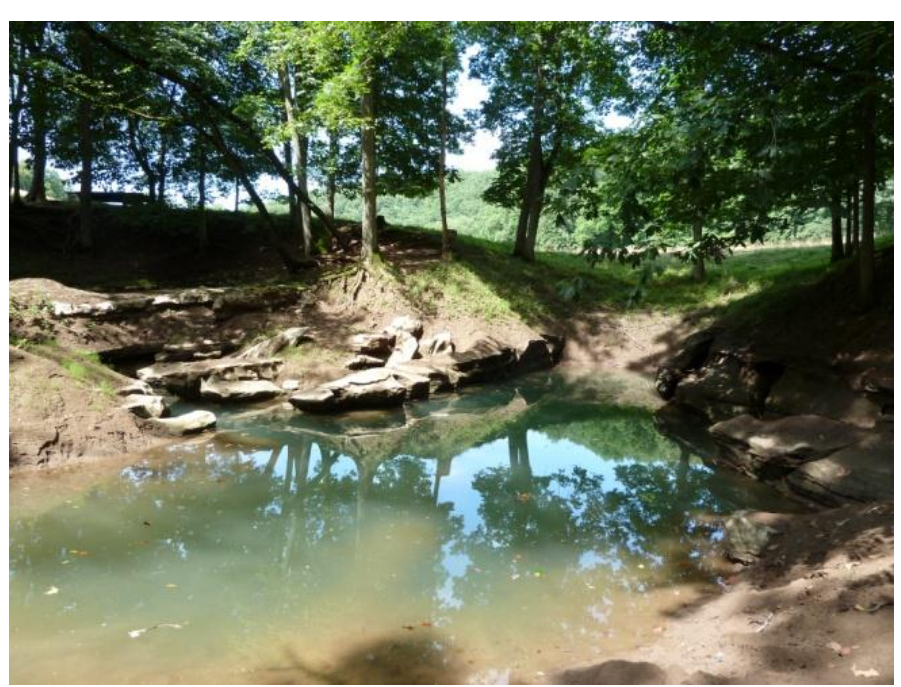

Photo 1: Circulating Cenote at low water on July 17, 2010. Water is flowing out of a spring on the left side of the limestone peninsula.

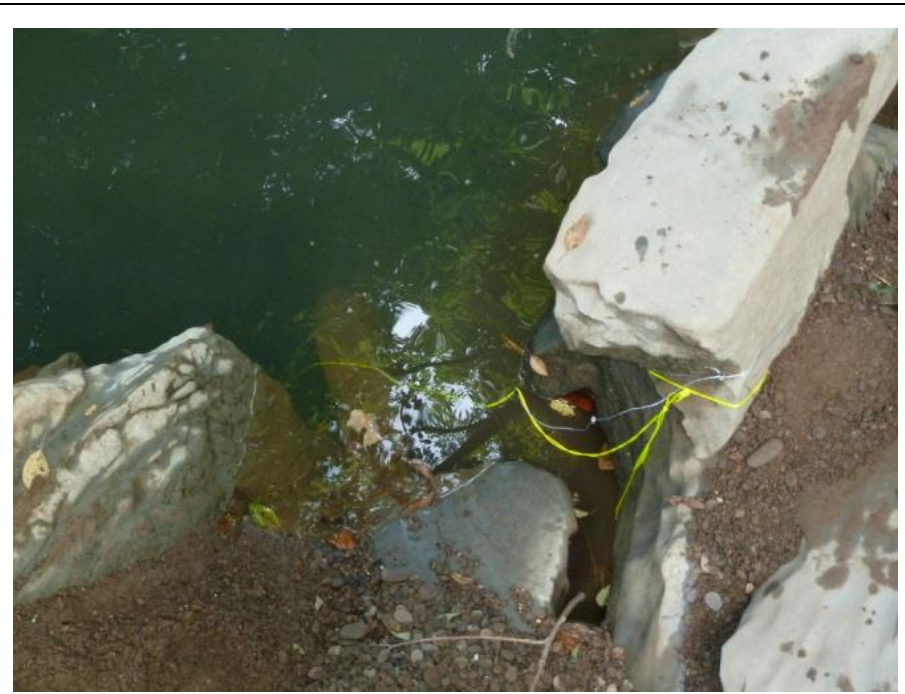

Photo 2: Onset Hobo Pendent UA-002-64 temperature and light data logger, attached to limestone ledge, submerged in Circulating Cenote.

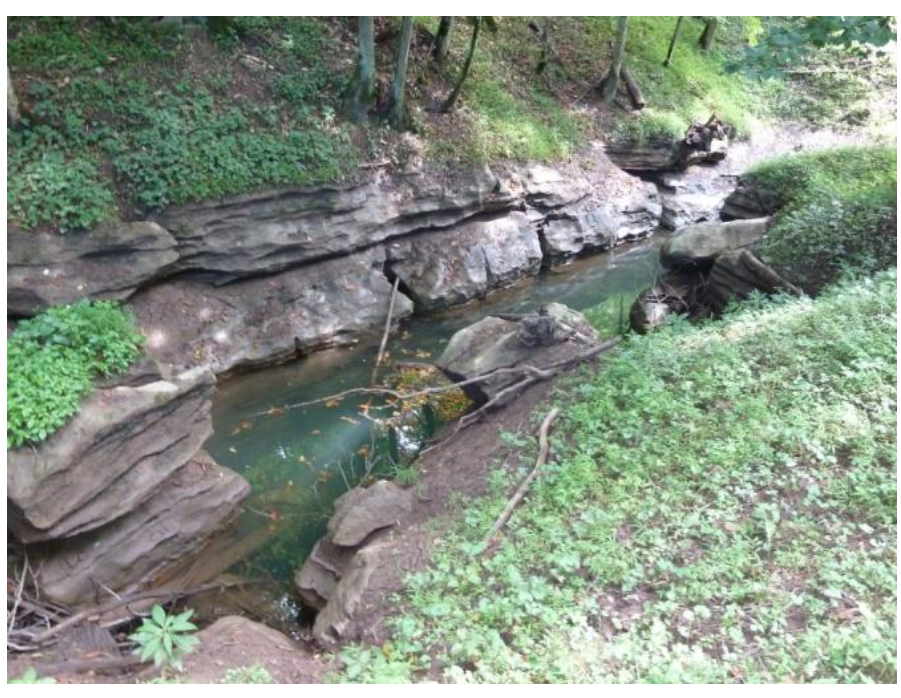

Photo 3: Smaller spring located next to Circulating Cenote, connected by surface flow to the cenote and Spring Creek in high water.

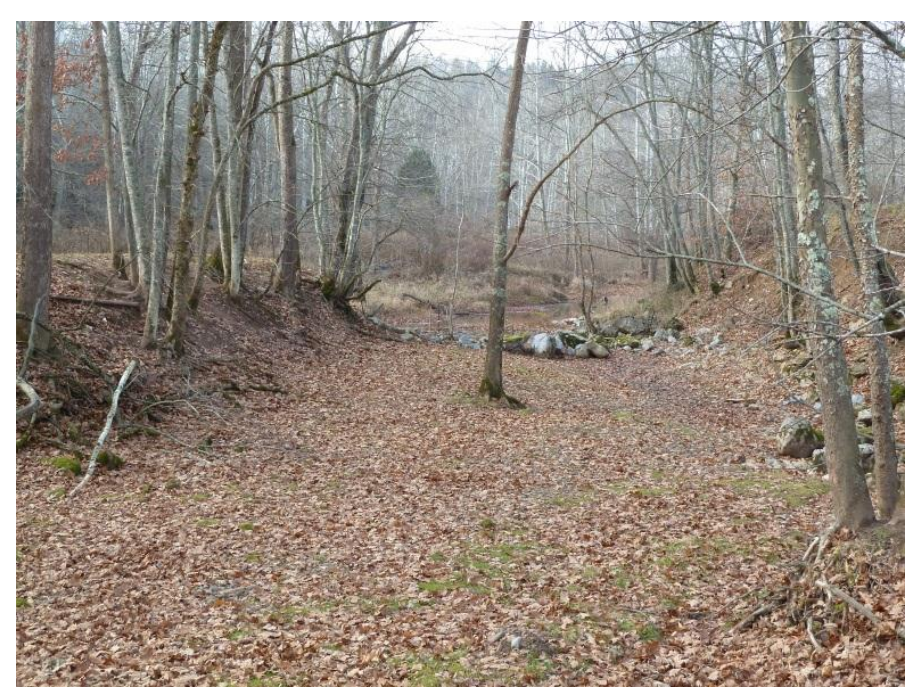

Photo 4: A dry surface channel connecting Circulating Cenote to Spring Creek, which conveys overflow during wet weather. 


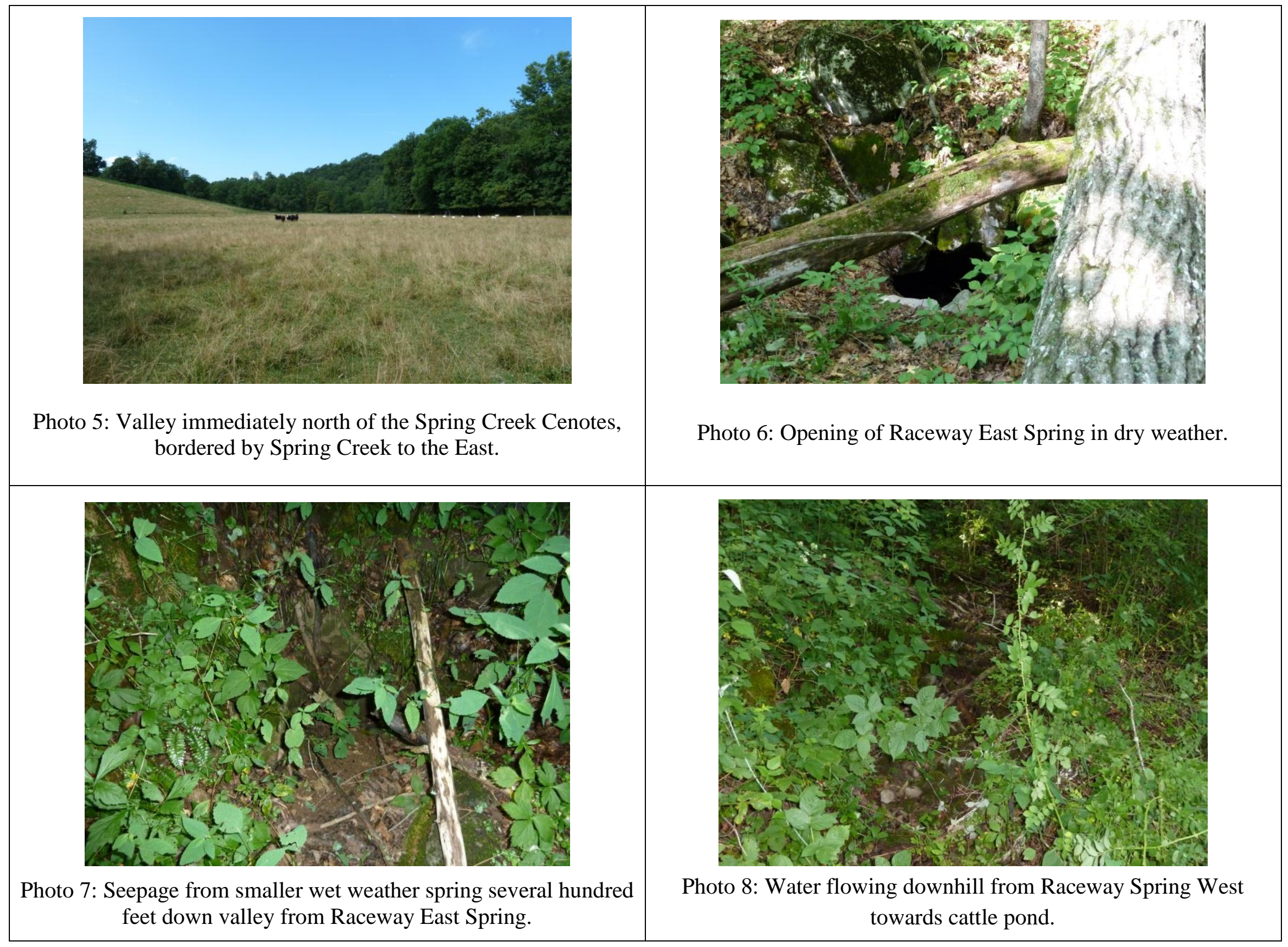




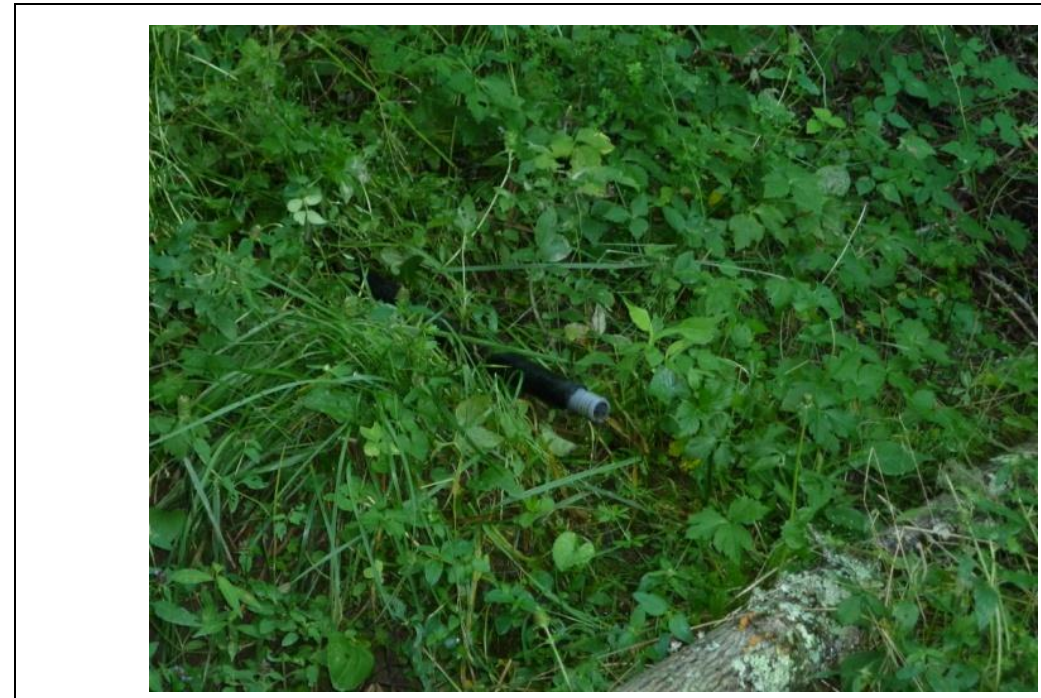

Photo 9: Water line emerging downhill of Raceway Spring West to direct water to pond.

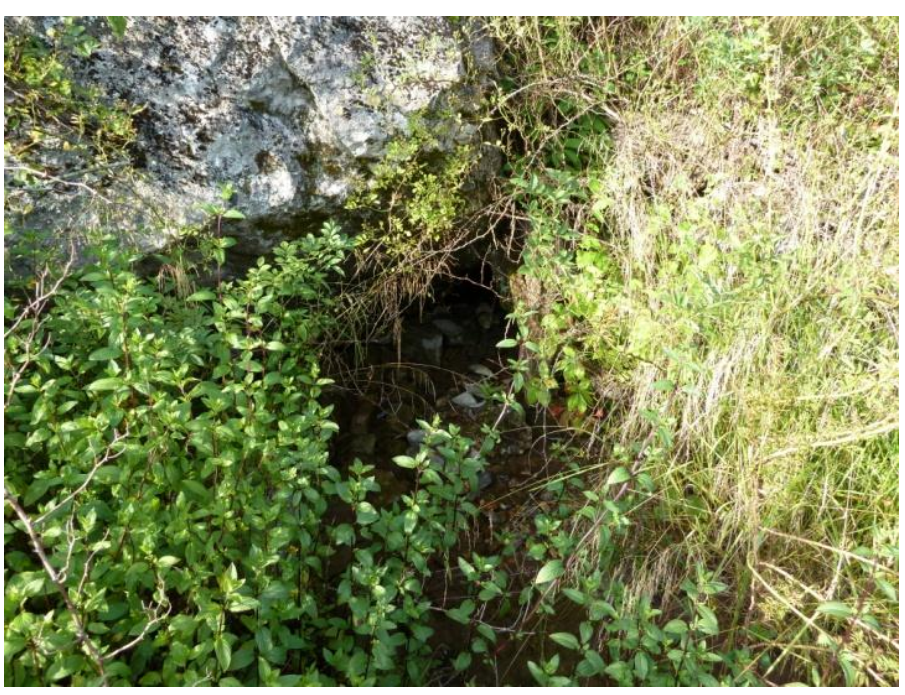

Photo 11: Opening of Apple Spring, under a large limestone rock.

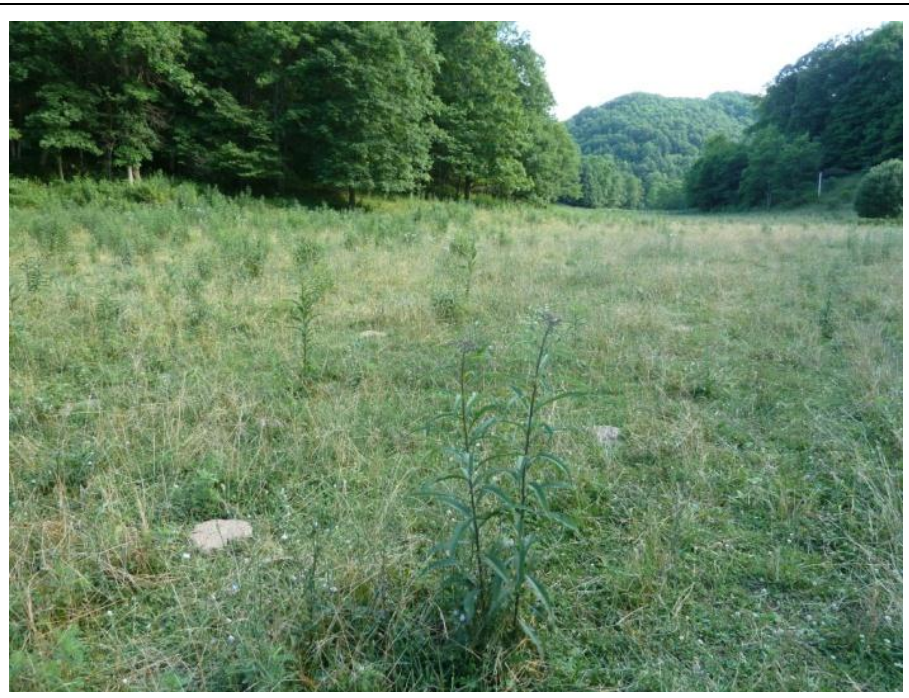

Photo 10: The Racetrack, viewing south.

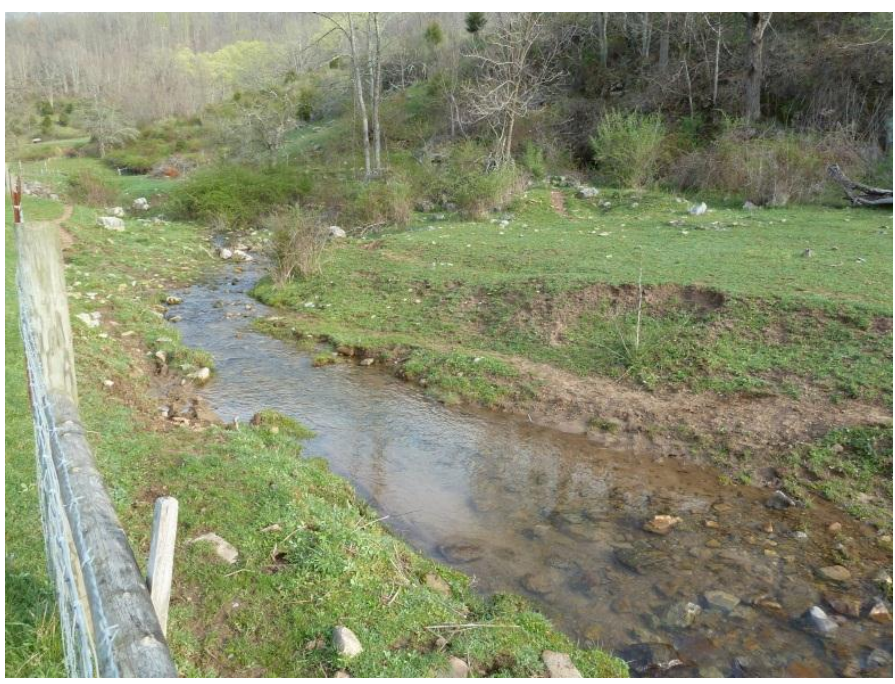

Photo 12: Surface channel fed by Apple Spring, flowing toward Buckeye Creek Cave, surrounded by heavily grazed pasture. 


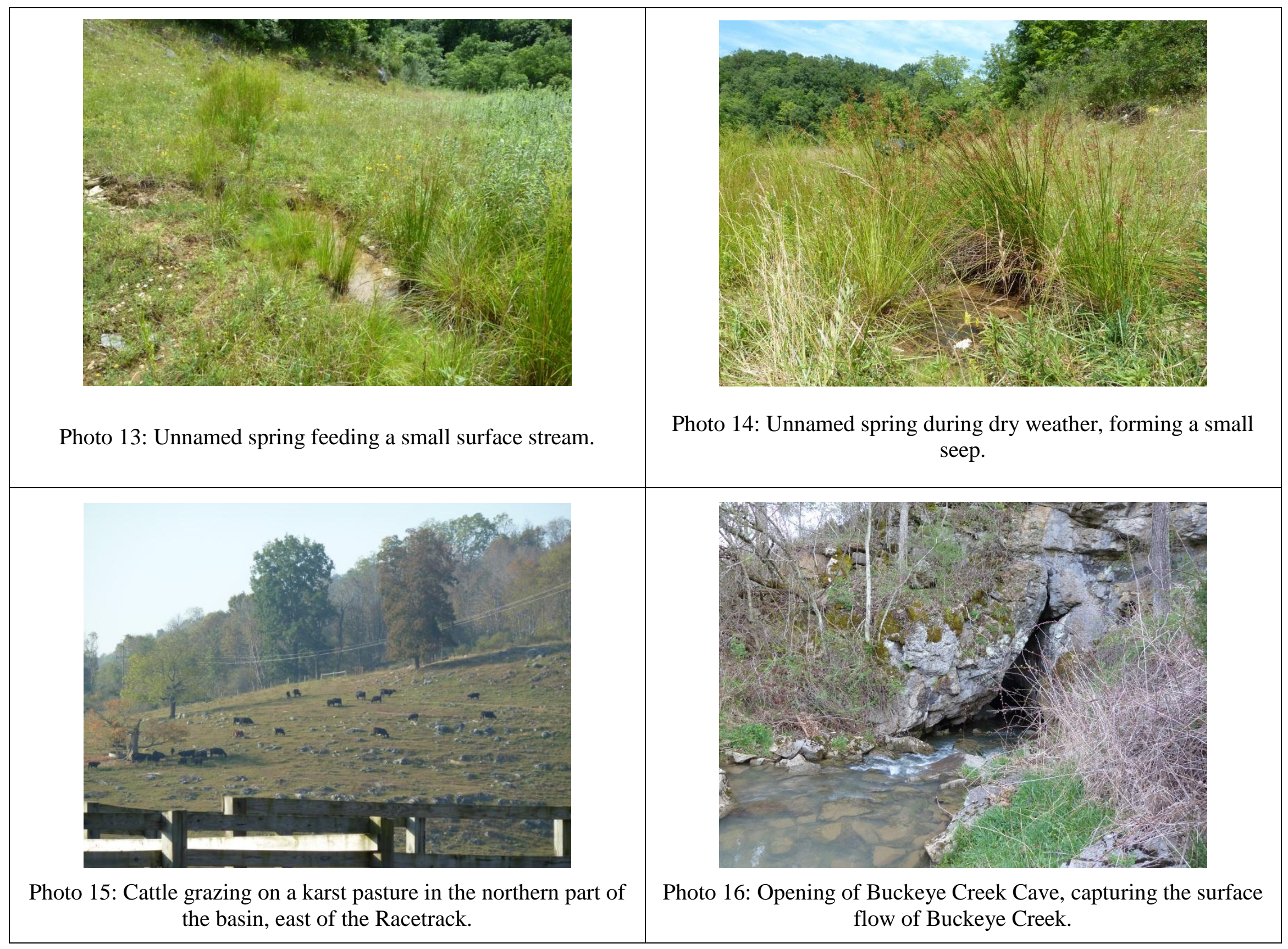




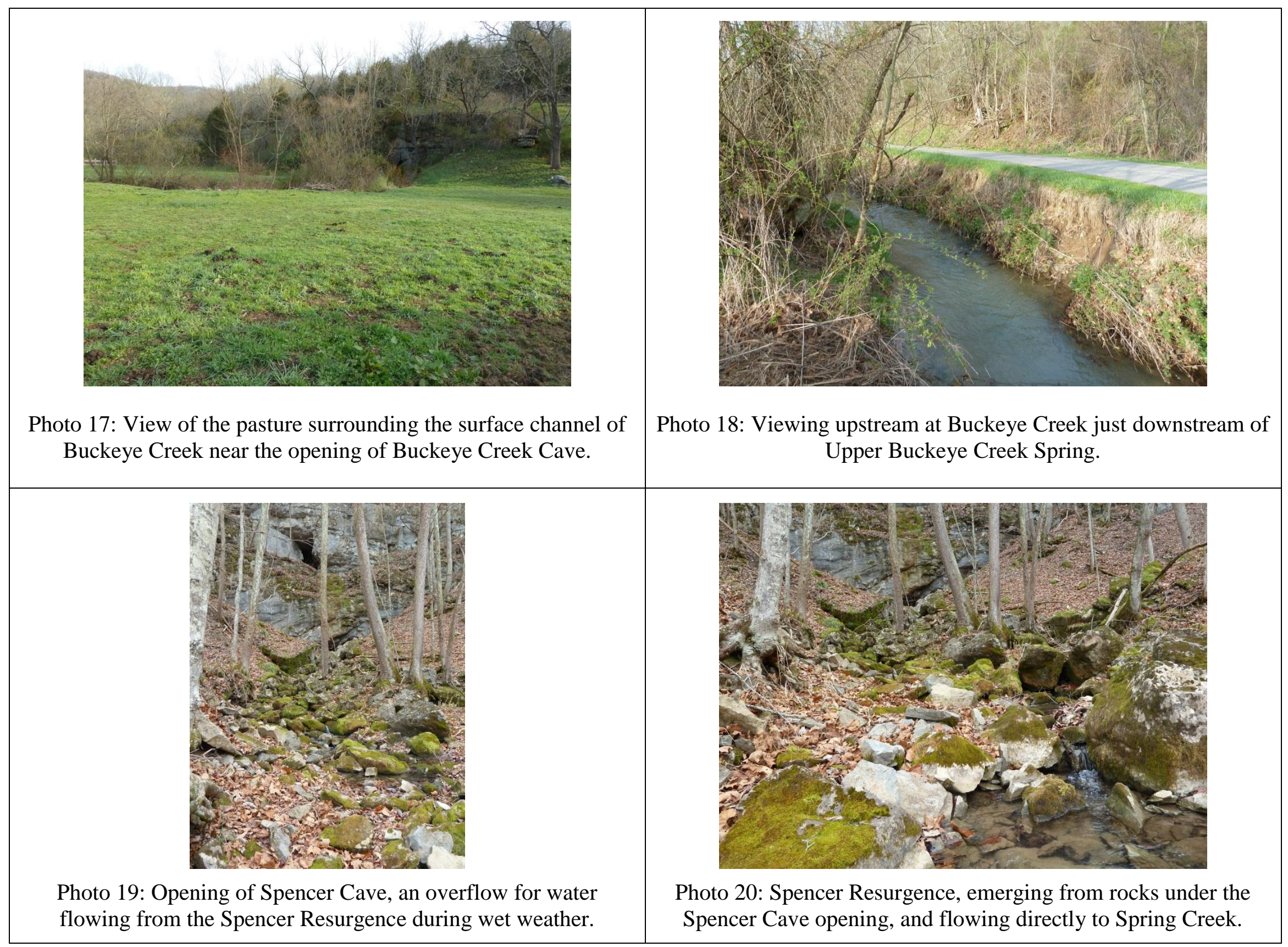




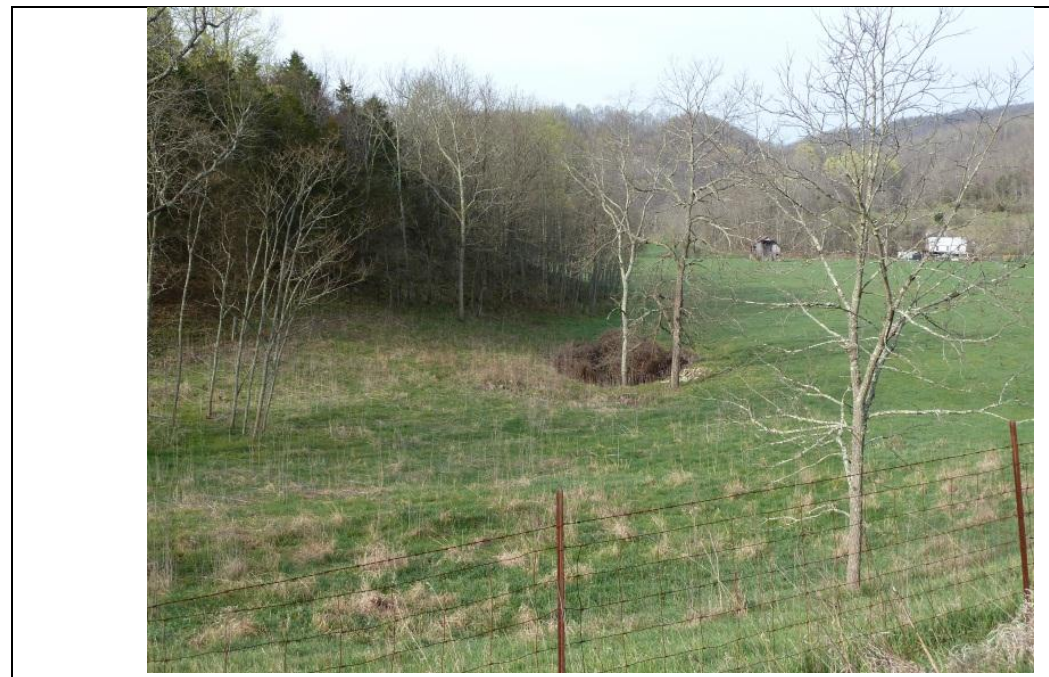

Photo 21: A sinkhole in a pasture just east of the Racetrack, possibly hydrologically connected to Buckeye Creek Cave.

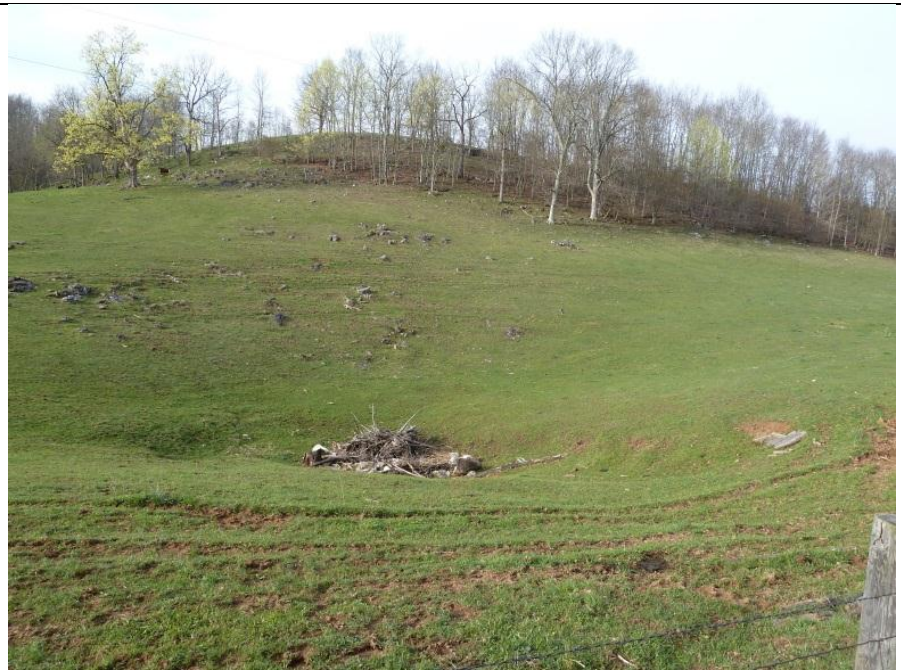

Photo 22: A sinkhole in a pasture area northeast of the Racetrack, near the low point of the groundwater surface elevation, as modeled by Kriging in this study.

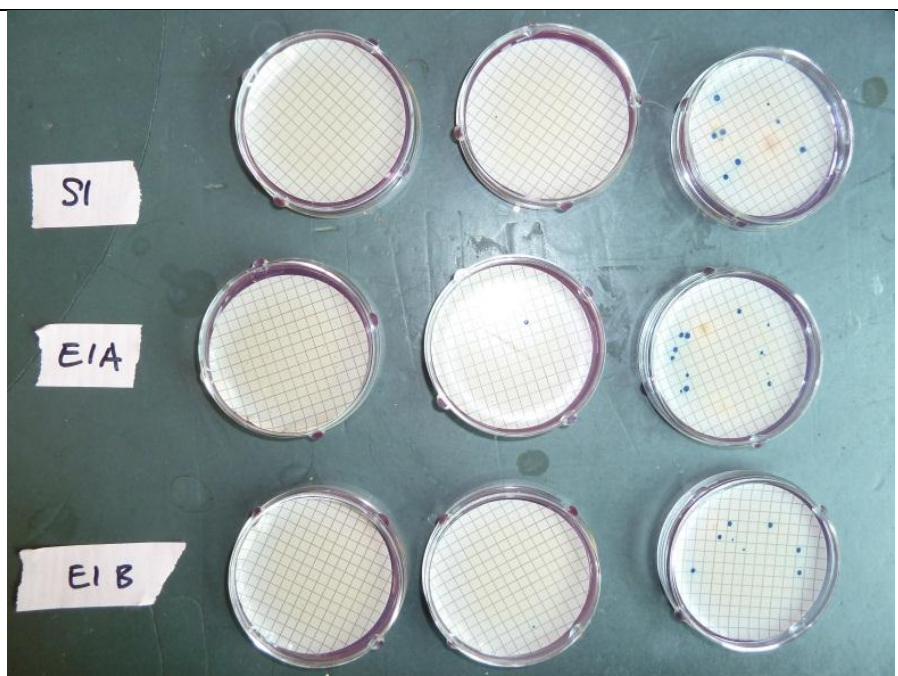

Photo 24: Examples of fecal coliform numeration after 24 hours incubation at $44.5^{\circ} \mathrm{C}$. Blue spots visible on the membrane filters represent one colony forming unit.
Photo 23: Examples of fecal coliform numeration after 24 hours incubation at $44.5^{\circ} \mathrm{C}$. Dishes are arranged from left to right: $1 \mathrm{ml}$, $10 \mathrm{ml}$, and $100 \mathrm{ml}$ test volumes. 


\section{Appendix G: Quality Control Data}

Table G-1. Duplicate Data for Fecal Coliform Samples

\begin{tabular}{|c|c|c|c|c|c|c|c|}
\hline $\begin{array}{c}\text { Sample } \\
\text { Date }\end{array}$ & $\begin{array}{l}\text { Sample } \\
\text { Location }\end{array}$ & Sample & $\begin{array}{c}\text { CFU/100 } \\
\mathrm{mL}\end{array}$ & $\begin{array}{c}\text { CFU/10 } \\
\mathrm{mL}\end{array}$ & $\begin{array}{c}\mathrm{CFU} / 1 \\
\mathrm{~mL}\end{array}$ & $\begin{array}{l}\text { Calculated } \\
\text { CFU/100 mL }\end{array}$ & $\begin{array}{l}\text { \% Difference in } \\
\text { Calculated } \\
\text { CFU/100 mL }\end{array}$ \\
\hline \multirow[t]{2}{*}{$9 / 16 / 2010$} & \multirow[t]{2}{*}{ US } & Test Sample & 127 & 11 & 0 & 127 & \multirow[b]{2}{*}{23} \\
\hline & & Duplicate & 98 & 3 & 1 & 98 & \\
\hline \multirow[t]{2}{*}{$9 / 23 / 2010$} & \multirow[t]{2}{*}{ RW } & Test Sample & 3 & 1 & 0 & 3 & \multirow[b]{2}{*}{100} \\
\hline & & Duplicate & 6 & 0 & 0 & 6 & \\
\hline \multirow[t]{2}{*}{$9 / 23 / 2010$} & \multirow[t]{2}{*}{ UBCS } & Test Sample & $>300$ & 51 & 23 & 510 & \multirow[b]{2}{*}{237} \\
\hline & & Duplicate & $>300$ & 172 & 4 & 1720 & \\
\hline \multirow[t]{2}{*}{$1 / 19 / 2011$} & \multirow[t]{2}{*}{ BCCE } & Test Sample & 35 & 2 & 0 & 35 & \multirow[b]{2}{*}{17} \\
\hline & & Duplicate & 29 & 4 & 0 & 29 & \\
\hline \multirow[t]{2}{*}{$1 / 24 / 2011$} & \multirow[t]{2}{*}{ UBCS } & Test Sample & 6 & 0 & 0 & 6 & \multirow[b]{2}{*}{50} \\
\hline & & Duplicate & 9 & 1 & 0 & 9 & \\
\hline \multirow[t]{2}{*}{$1 / 24 / 2011$} & \multirow[t]{2}{*}{ BCCE } & Test Sample & 14 & 0 & 0 & 14 & \multirow[b]{2}{*}{57} \\
\hline & & Duplicate & 6 & 0 & 0 & 6 & \\
\hline \multirow[t]{2}{*}{$1 / 24 / 2011$} & \multirow[t]{2}{*}{ SR } & Test Sample & 1 & 0 & 0 & 1 & \multirow[b]{2}{*}{100} \\
\hline & & Duplicate & 2 & 0 & 0 & 2 & \\
\hline \multirow[t]{2}{*}{$1 / 31 / 2011$} & \multirow[t]{2}{*}{ AS } & Test Sample & 11 & 2 & 0 & 11 & \multirow[b]{2}{*}{0} \\
\hline & & Duplicate & 11 & 1 & 0 & 11 & \\
\hline \multirow[t]{2}{*}{$1 / 31 / 2011$} & \multirow[t]{2}{*}{ RW } & Test Sample & 36 & 2 & 0 & 36 & \multirow[b]{2}{*}{11} \\
\hline & & Duplicate & 40 & 2 & 0 & 40 & \\
\hline \multirow[t]{2}{*}{ 4/18/2011 } & \multirow[t]{2}{*}{ BCCE } & Test Sample & 13 & 1 & 0 & 13 & \multirow[b]{2}{*}{31} \\
\hline & & Duplicate & 9 & 1 & 0 & 9 & \\
\hline \multirow[t]{2}{*}{ 4/18/2011 } & SR & Test Sample & 10 & 2 & 0 & 10 & \\
\hline & & Duplicate & 8 & 1 & 0 & 8 & 20 \\
\hline $4 / 28 / 2011$ & AS & Test Sample & $>300$ & 110 & 11 & 1100 & \\
\hline & & Duplicate & $>300$ & 103 & 19 & 1465 & 33 \\
\hline $4 / 28 / 2011$ & US & Test Sample & $>300$ & 68 & 2 & 680 & \\
\hline & & Duplicate & $>300$ & 52 & 1 & 520 & 24 \\
\hline & & & & & & $\begin{array}{r}\text { Mean \% } \\
\text { Difference: }\end{array}$ & 54 \\
\hline
\end{tabular}

Sample location abbreviations: US = Unnamed Spring, RW = Raceway West, UBCS $=$ Upper Buckeye Creek Spring, $\mathrm{BCCE}=$ Buckeye Creek Cave Entrance, SR = Spencer Resurgence, AS = Apple Spring. 
Table G-2. Calibration Standard Data for Ion Analysis

\begin{tabular}{|c|c|c|c|c|c|c|c|c|}
\hline & & \multicolumn{7}{|c|}{ Anion Concentration (mg/L) } \\
\hline Test & & $\mathrm{Fl}^{-}$ & $\mathrm{Cl}^{-}$ & $\mathrm{NO}_{2}^{-}-\mathrm{N}$ & $\mathrm{SO}_{4}{ }^{2-}-\mathrm{S}$ & $\mathrm{Br}^{-}$ & $\mathrm{NO}_{3}^{-}-\mathrm{N}$ & $\mathrm{PO4}^{3-}-\mathrm{P}$ \\
\hline \multirow[b]{2}{*}{ A1 } & Standard Used & 0.10 & 0.50 & 0.15 & 0.17 & 0.50 & 0.11 & 0.33 \\
\hline & Measured & 0.08 & 0.37 & 0.14 & 0.13 & 0.34 & 0.07 & 0.20 \\
\hline \multirow[b]{2}{*}{$\mathrm{A} 2$} & Standard Used & 1.00 & 5.00 & 1.52 & 1.67 & 5.00 & 1.13 & 3.26 \\
\hline & Measured & 1.02 & 4.68 & 1.63 & 1.55 & 4.43 & 1.01 & 2.86 \\
\hline \multirow[b]{2}{*}{ A3 } & Standard Used & 5.00 & 25.00 & 7.61 & 8.35 & 25.00 & 5.65 & 16.31 \\
\hline & Measured & 5.05 & 24.38 & 7.79 & 8.08 & 24.16 & 5.46 & 15.79 \\
\hline \multirow[b]{2}{*}{ A4 } & Standard Used & 10.00 & 50.00 & 15.22 & 16.69 & 50.00 & 11.30 & 32.61 \\
\hline & Measured & 9.98 & 50.34 & 15.12 & 16.84 & 50.48 & 11.41 & 32.91 \\
\hline
\end{tabular}

\begin{tabular}{|l|lr|r|r|r|r|r|}
\cline { 3 - 8 } \multicolumn{2}{c|}{} & \multicolumn{7}{c|}{ Cation Concentration $\mathbf{( m g / L}$} \\
\hline \multirow{3}{*}{ Test } & & $\mathbf{L i}^{+}$ & $\mathbf{N a}^{+}$ & $\mathbf{N H}_{4}{ }^{+}-\mathbf{N}$ & $\mathbf{K}^{+}$ & $\mathbf{M g}^{2+}$ & $\mathbf{C a}^{2+}$ \\
\hline \multirow{3}{*}{ C1 } & Standard Used & 0.08 & 0.32 & 0.31 & 0.80 & 0.40 & 0.80 \\
\cline { 2 - 9 } C2 & Measured & 0.03 & 2.10 & 0.75 & 0.27 & 0.15 & 0.46 \\
\hline \multirow{3}{*}{ C3 } & Standard Used & 0.40 & 1.60 & 1.55 & 4.00 & 2.00 & 4.00 \\
\cline { 2 - 9 } & Measured & 0.27 & 4.21 & 1.92 & 2.63 & 0.95 & 3.02 \\
\cline { 2 - 9 } & Standard Used & 2.00 & 8.00 & 7.77 & 20.00 & 11.00 & 20.00 \\
\hline \multirow{3}{*}{ C4 } & Standard Used & 1.79 & 9.19 & 7.64 & 17.86 & 8.32 & 19.89 \\
\cline { 2 - 9 } & Measured & 10.00 & 40.00 & 38.85 & 100.00 & 50.00 & 100.00 \\
\hline
\end{tabular}


Table G-3. Duplicate Ion Analysis Data

\begin{tabular}{|c|c|c|c|c|c|}
\hline $\begin{array}{l}\text { Sample } \\
\text { Date }\end{array}$ & $\begin{array}{l}\text { Sample } \\
\text { Location }\end{array}$ & Sample & $\begin{array}{l}\mathrm{Ca}^{2+} \\
\text { Conc. } \\
\text { (mg/l) }\end{array}$ & $\begin{array}{l}\mathrm{Mg}^{2+} \\
\text { Conc. } \\
\text { (mg/l) }\end{array}$ & $\begin{array}{l}\mathrm{NO}_{3}^{-} \\
\text {Conc. } \\
\text { (mg/l) }\end{array}$ \\
\hline \multirow[b]{2}{*}{$9 / 16 / 2010$} & \multirow[b]{2}{*}{ US } & $\begin{array}{r}\text { Test } \\
\text { Sample } \\
\end{array}$ & 50.73 & 11.01 & 0.10 \\
\hline & & Duplicate & 62.12 & 11.36 & 0.13 \\
\hline \multirow[b]{2}{*}{$9 / 23 / 2010$} & \multirow[b]{2}{*}{ UBCS } & $\begin{array}{r}\text { Test } \\
\text { Sample }\end{array}$ & 50.43 & 6.75 & 0.00 \\
\hline & & Duplicate & 53.62 & 7.04 & 0.00 \\
\hline \multirow[b]{2}{*}{$1 / 19 / 2011$} & \multirow[b]{2}{*}{ BCCE } & $\begin{array}{r}\text { Test } \\
\text { Sample }\end{array}$ & 44.43 & 3.29 & 0.50 \\
\hline & & Duplicate & 51.19 & 3.90 & 0.47 \\
\hline \multirow[b]{2}{*}{$1 / 24 / 2011$} & \multirow[b]{2}{*}{ BCCE } & $\begin{array}{r}\text { Test } \\
\text { Sample }\end{array}$ & 49.51 & 3.70 & 0.64 \\
\hline & & Duplicate & 48.78 & 3.51 & 0.67 \\
\hline \multirow[b]{2}{*}{$1 / 24 / 2011$} & \multirow[b]{2}{*}{ SR } & $\begin{array}{r}\text { Test } \\
\text { Sample }\end{array}$ & 47.57 & 4.36 & 1.29 \\
\hline & & Duplicate & 50.02 & 4.65 & 1.28 \\
\hline \multirow[b]{2}{*}{$1 / 31 / 2011$} & \multirow[b]{2}{*}{ UBCS } & $\begin{array}{r}\text { Test } \\
\text { Sample } \\
\end{array}$ & 45.94 & 3.35 & 0.69 \\
\hline & & Duplicate & 43.01 & 3.20 & 0.70 \\
\hline \multirow[b]{2}{*}{$4 / 28 / 2011$} & \multirow[b]{2}{*}{ AS } & $\begin{array}{r}\text { Test } \\
\text { Sample } \\
\end{array}$ & 19.05 & 1.80 & 0.62 \\
\hline & & Duplicate & 18.91 & 1.79 & 0.62 \\
\hline
\end{tabular}

Table G-4. Percent Difference in Ion Analysis Duplicates Data

\begin{tabular}{|l|l|r|r|r|}
\hline $\begin{array}{l}\text { Sample } \\
\text { Date }\end{array}$ & $\begin{array}{l}\text { Sample } \\
\text { Location }\end{array}$ & $\begin{array}{l}\text { \% } \\
\text { Difference } \\
\text { Ca2+ }\end{array}$ & $\begin{array}{l}\text { \% } \\
\text { Difference } \\
\text { Mg2+ }\end{array}$ & $\begin{array}{l}\text { \% } \\
\text { Difference } \\
\text { NO3- }\end{array}$ \\
\hline $9 / 16 / 2010$ & US & 22.45 & 3.18 & 30.00 \\
\hline $9 / 23 / 2010$ & UBCS & 6.33 & 4.30 & 0.00 \\
\hline $1 / 19 / 2011$ & BCEE & 15.21 & 18.54 & 6.00 \\
\hline $1 / 24 / 2011$ & BCEE & 1.47 & 5.14 & 4.69 \\
\hline $1 / 24 / 2011$ & SR & 5.15 & 6.65 & 0.78 \\
\hline $1 / 31 / 2011$ & UBCS & 6.38 & 4.48 & 1.45 \\
\hline $4 / 28 / 2011$ & AS & 0.73 & 0.56 & 0.00 \\
\hline
\end{tabular}

Sample location abbreviations: US = Unnamed Spring, RW = Raceway West, UBCS = Upper Buckeye Creek Spring, BCCE = Buckeye Creek Cave Entrance, SR = Spencer Resurgence, AS = Apple Spring. 